\title{
Synthetic and Structural Studies of Phosphine Coordinated Boronium Salts
}

R

I

\begin{abstract}
Anthony F. Hill*a and Jas S. Ward ${ }^{a}$
The reaction of $\mathrm{BrH}_{2} \mathrm{~B} \cdot \mathrm{SMe}_{2}$ with primary and secondary phosphines affords a range of boronium salts of the form $\left[\mathrm{H}_{2} \mathrm{~B}\left(\mathrm{PR}_{3}\right)_{2}\right] \mathrm{Br}\left(\mathrm{PR}_{3}=\mathrm{PHCy}_{2} 1 ; \mathrm{PHPh}_{2}, 2 ; \mathrm{PH}_{2} \mathrm{Cy}, 3\right)$, which have been fully characterised including solid-state determinations. Reactions of bulky tertiary phosphines, e.g., $\mathrm{PCy}_{3}$ and $\mathrm{PPh}_{3}$, with $\mathrm{BrH}_{2} \mathrm{~B} \cdot \mathrm{SMe}_{2}$ does not proceed beyond the phosphinestabilised bromoborane adducts, however, the smaller tertiary phosphine $\mathrm{PMe}_{2} \mathrm{Ph}$ readily proceeds to form $\left[\mathrm{H}_{2} \mathrm{~B}\left(\mathrm{PMe} \mathrm{PM}_{2} \mathrm{Ph} \mathrm{Br}\right.\right.$ (4). The formation of the unsymmetrical boronium salts $\left[\mathrm{H}_{2} \mathrm{~B}\left(\mathrm{PH}_{2} \mathrm{Cy}\right)(\mathrm{PHCy})\right] \mathrm{Br} \quad(5)$ and $\left[\mathrm{H}_{2} \mathrm{~B}\left(\mathrm{PHCy}_{2}\right)\left(\mathrm{PHPh}_{2}\right)\right] \mathrm{Br}$ (6) was observed by in situ NMR spectroscopy, however, the compounds were found to spontaneously disproportionate to their respective homophosphine boronium cations, even on prolonged storage in solution at $-78^{\circ} \mathrm{C}$. Di- and triphosphines were found to form ring-closed boronium salts to afford $\left[\mathrm{H}_{2} \mathrm{~B}\left(\kappa^{2}-P, P^{\prime}\right.\right.$-diphosphine $\left.)\right] \mathrm{Br}$ (diphosphine = dppe, 7; dcpe, 8; dmpe, 9; dppf, 10; dppf with [AsF $]^{-}$counterion, 11; amphos, 12). The analogous methodology with $\mathrm{Br}_{2} \mathrm{HB} \cdot \mathrm{SMe}_{2}$ proved less generally applicable due to an accessible decomposition pathway being available to boronium salts bearing primary and secondary phosphines, leading to the formation of phosphonium salts, although $[\mathrm{BrHB}(\mathrm{dcpe})] \mathrm{Br}(\mathbf{1 3}),\left[\mathrm{BrHB}\left(\mathrm{PMe} \mathrm{e}_{2} \mathrm{Ph}\right)_{2}\right] \mathrm{Br}(\mathbf{1 4})$ and $[\mathrm{BrHB}(\mathrm{amphos})] \mathrm{Br}$ (15) were synthesised with varying degrees of success. Reaction of $\mathrm{BrH}_{2} \mathrm{~B} \cdot \mathrm{SMe} 2$ with diphars afforded the boronium salt $\left[\mathrm{H}_{2} \mathrm{~B}\left(\kappa^{2}-P, P^{\prime}\right.\right.$-diphars $\left.)\right] \mathrm{Br}(\mathbf{1 6})$, which featured two pendant arsine arms. Similarly, triphos was found to react with $\mathrm{BrH}_{2} \mathrm{~B} \cdot \mathrm{SMe}_{2}$ to give $\left[\mathrm{H}_{2} \mathrm{~B}\left(\kappa^{2}-P, P^{\prime}\right.\right.$-triphos $\left.)\right] \mathrm{Br}(17)$, which featured a pendant phosphine arm. Substitution of the bromide counter anion with either hexafluoroarsenate or hexfluoroantimonate anions revealed weak hydrogen bonds between the $\mathrm{P}-\mathrm{H}$ bonds of the boronium cations and the anions, that appeared through NMR studies to be retained in solution (where hydrogen bonding order was determined to be $\mathrm{Br}^{-}>\left[\mathrm{SbF}_{6}\right]^{-} /\left[\mathrm{AsF}_{6}\right]^{-}$). This was further demonstrated by comparison of solid-state structures and solution NMR data of 1 with $\left[\mathrm{H}_{2} \mathrm{~B}\left(\mathrm{PHCy}_{2}\right)_{2}\right]\left[\mathrm{SbF}_{6}\right]$ (18), 4 with $\left[\mathrm{H}_{2} \mathrm{~B}\left(\mathrm{PMe}_{2} \mathrm{Ph}\right)_{2}\right]\left[\mathrm{AsF}_{6}\right]$ (19) and 17 with $\left[\mathrm{H}_{2} \mathrm{~B}\right.$ (triphos)][AsF6] (20).
\end{abstract}

\section{Introduction}

Effective catalytic processes for the formation of main group element bonds is an important objective for the development of main group chemistry. Progress in this field enables new discoveries and applications to be revealed in areas in which main group elements are already finding success, such as high performance polymers and frustrated Lewis pairs. ${ }^{1,2}$ Boronium cations, where a boron centre bears two $\sigma$-bound substituents and two datively (polar covalent) bound substituents supporting boron bearing a formal positive charge, were first suggested by Parry and co-workers. ${ }^{3,4}$ Interest in stabilising boronium species has been consistent, however, a large proportion of these endeavors have involved nitrogen based substituents. ${ }^{5}$ A notable exception is the recent isolation by Bertrand et al. of a bis( $\mathrm{N}$-heterocyclic carbene)boronium salt (Scheme 1). ${ }^{6}$

Research School of Chemistry, The Australian National University, Canberra, ACT 2601, Australia. Email: a.hill@anu.edu.au
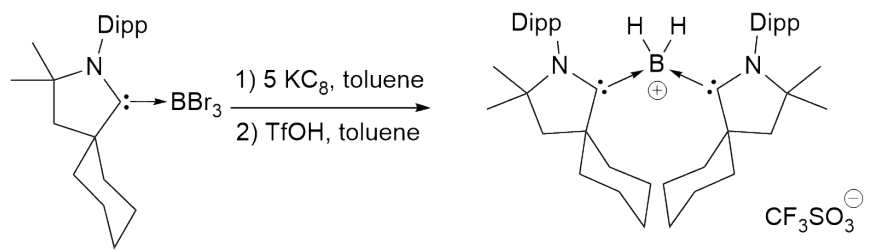

Scheme 1: Synthesis of a bis( $N$-heterocyclic carbene)boronium salt (Dipp $=2,6$ diisopropylphenyl). ${ }^{6}$

A number of bis(phosphine)boronium salts of the form $\left[\mathrm{H}_{2} \mathrm{~B}\left(\mathrm{PR}_{3}\right)\right] \mathrm{X}$ have been described previously, ${ }^{7}$ albeit sporadically, with the most extensive studies being provided by Schmidbaur. ${ }^{8}$ Nevertheless, remarkably few structural data are available (Table 1), whilst those for monohalobis(phosphine) boronium salts ${ }^{7 b, h}$ are limited to those for the heterocyclic salts $\left[\mathrm{C}_{2} \mathrm{H}_{2}\left(\mathrm{PPh}_{2}\right)_{2} \mathrm{BHBr}\right] \mathrm{Br}$ and $\left[\mathrm{C}_{6} \mathrm{H}_{4}\left(\mathrm{PPh}_{2}\right)_{2} \mathrm{BHBr}\right] \mathrm{Br} .{ }^{8 \mathrm{~g}}$ Data for secondary phosphine ligated boronium salts are especially rare, being limited to $\left[\mathrm{H}_{2} \mathrm{~B}\left(\mathrm{PH}^{t} \mathrm{Bu}_{2}\right)_{2}\right] \mathrm{X}\left(\mathrm{X}=\mathrm{B}\left\{\mathrm{C}_{6} \mathrm{H}_{3}\left(\mathrm{CF}_{3}\right)_{2}-3,5\right\}_{4}\right.$, OTf, $\mathrm{Br}) .{ }^{7 i}$ With the exception of Scheer's BPBPB catenated salt $\left[\mathrm{H}_{2} \mathrm{~B}\left(\mathrm{PH}_{2} \mathrm{BH}_{2} \mathrm{NMe}_{3}\right)_{2}\right] \mathrm{X}\left(\mathrm{X}=\mathrm{I}, \mathrm{VCl}_{4}(\mathrm{THF})_{2}\right)^{9}$ which might be described as two primary phosphines coordinated to a cationic $\mathrm{BH}_{2}$ unit, conventional primary phosphine adducts have yet to be structurally characterised. Boronium salts ligated by secondary or primary phosphines are however of current interest in the context of dehydrocoupling en route to phosphine-borane oligomers. . $^{\mathrm{i}, \mathrm{j}}$ 
With an ever-increasing number of phosphines becoming available, offering variations in both steric and electronic properties, $^{11}$ the pursuit of diverse phosphorus-based boronium species appeared worthwhile. We report herein, the reactions of haloborane thioether adducts with a range of primary, secondary and tertiary, mono and polydentate phosphines that display differing electronic and steric features in addition to different propensities towards chelation.

Table 1. Selected Structural Data for Dihydrobis(phosphine) Boronium Salts $\left[\mathrm{H}_{2} B L_{2}\right] \mathrm{X}$

\begin{tabular}{|c|c|c|c|c|}
\hline $\mathrm{L}=$ & $x$ & $P-B\left(L^{1}\right)$ & $P-B\left(L^{2}\right)$ & P-B-P \\
\hline \multirow{3}{*}{$\mathrm{PEt}_{3}{ }^{\mathrm{a}, 7 \mathrm{e}}$} & & $\AA$ & $\AA$ & deg. \\
\hline & $\mathrm{B}\left(\mathrm{O}_{2} \mathrm{C}_{6} \mathrm{H}_{4}\right)_{2}$ & 1.904 & 1.911 & 119.8 \\
\hline & & 1.911 & 1.897 & 118.4 \\
\hline $\mathrm{PH}_{2} \mathrm{BH}_{2} \mathrm{NMe}_{3}{ }^{9}$ & I & 1.948 & 1.948 & 108.2 \\
\hline $\mathrm{PH}_{2} \mathrm{BH}_{2} \mathrm{NMe}_{3}{ }^{9}$ & $\mathrm{VCl}_{4}(\mathrm{THF})_{2}$ & 1.950 & 1.930 & 111.4 \\
\hline $\mathrm{PPh}_{2} \mathrm{Fe}(\mathrm{CO})_{2}(\mathrm{Cp})^{10}$ & $\mathrm{FeCl}_{4}$ & 1.967 & 1.967 & 123.3 \\
\hline $\mathrm{PH}^{t} \mathrm{Bu}_{2}{ }^{7 \mathrm{i}}$ & $\mathrm{Br}$ & 1.948 & 1.934 & 118.9 \\
\hline $\mathrm{PH}^{t} \mathrm{Bu}_{2 \mathrm{a}}{ }^{a, 7 \mathrm{i}}$ & $\mathrm{BArF}_{4}$ & 1.937 & 1.933 & 118.7 \\
\hline $\mathrm{PH}^{t} \mathrm{Bu}_{2}{ }^{7 \mathrm{i}}$ & & 1.940 & 1.938 & 118.8 \\
\hline
\end{tabular}

Heterocycles $L_{2}=$

$\begin{array}{lllll}1,8-\mathrm{C}_{10} \mathrm{H}_{6}\left(\mathrm{PPh}_{2}\right)_{2}{ }^{a, 7 h} & \mathrm{BArF}_{4} & 1.907 & 1.913 & 104.1 \\ \mathrm{PMe}_{2} \mathrm{PMe}_{2}^{8 \mathrm{e}} & \mathrm{Br} & 1.924 & 1.918 & 116.2 \\ {\left[\mathrm{MeC}(\mathrm{CHPPh})_{2}\right]^{-}} & - & 1.924 & 1.924 & 106.0 \\ 1,2-\mathrm{C}_{6} \mathrm{H}_{4}\left(\mathrm{PPh}_{2}\right)_{2}{ }^{8 \mathrm{~g}} & \mathrm{Br} & 1.941 & 1.939 & 97.9 \\ 1,2-\mathrm{C}_{2} \mathrm{H}_{4}\left(\mathrm{PMe}^{t} \mathrm{Bu}\right)_{2}{ }^{7 f} & \mathrm{~B}\left(\mathrm{O}_{2} \mathrm{C}_{6} \mathrm{H}_{4}\right)_{2} & 1.936 & 1.968 & 98.5\end{array}$

${ }^{a}$ Two crystallographically independent molecules; ${ }^{b} \mathrm{BAr}_{4}=\left[\mathrm{B}\left\{\mathrm{C}_{6} \mathrm{H}_{3}\left(\mathrm{CF}_{3}\right)_{2}-3,5\right\}_{4}\right]^{-}$.

\section{Results and Discussion}

The previously reported boronium cations with secondary phosphines, $\left[\mathrm{H}_{2} \mathrm{~B}\left(\mathrm{PHR}_{2}\right)_{2}\right] \mathrm{Br}(\mathrm{R}=\mathrm{Cy}, \mathbf{1} ; \mathrm{Ph}, 2){ }^{7, j}$ were generated in good yields by direct reaction of two equivalents of $\mathrm{PHR}_{2}$ with $\mathrm{BrH}_{2} \mathrm{~B} \cdot \mathrm{SMe}_{2}$ in pentane, so as to facilitate clean precipitation upon formation of the product. The boronium salt synthesised by reaction of two equivalents of cyclohexylphosphine, $\left[\mathrm{H}_{2} \mathrm{~B}\left(\mathrm{PH}_{2} \mathrm{Cy}\right)_{2}\right] \mathrm{Br}$ (3), was also obtained by this method. ${ }^{7 \mathrm{j}}$ However, despite the clean formation of $\mathbf{3}$, the analogous species $\left[\mathrm{H}_{2} \mathrm{~B}\left(\mathrm{PH}_{2} \mathrm{R}\right)_{2}\right] \mathrm{Br}(\mathrm{R}=\mathrm{Ph}$, Mesityl) could not be readily isolated in a straightforward manner.

Monitoring the formation of 1 by ${ }^{11} \mathrm{~B}$ NMR spectroscopy revealed first the consumption of the $\mathrm{BrH}_{2} \mathrm{~B} \cdot \mathrm{SMe}_{2}$ starting material $\left(\delta_{\mathrm{B}}-12.0\right)$ to form the adduct $\mathrm{C}_{2} \mathrm{HPBH}_{2} \mathrm{Br}\left(\delta_{\mathrm{B}}-27.9\right)$, followed by its conversion to $\left[\mathrm{H}_{2} \mathrm{~B}\left(\mathrm{PC} \mathrm{y}_{2} \mathrm{H}\right)_{2}\right] \mathrm{Br}\left(\delta_{\mathrm{B}}-45.2\right)$ (Scheme 2 ). The boronium salt was found to be the favored product, even when a 1:1 stoichiometry of reagents was employed, with the reaction proceeding completely to the boronium salt 1 within 10 minutes at ambient temperature. The ${ }^{11} \mathrm{~B}$ NMR data illustrated the shift to lower frequency as phosphine sequentially replaced first the thioether and then, more slowly, the halide to finally provide the boronium salt. Isolated neutral $\mathrm{Cy}_{2} \mathrm{HP} . \mathrm{BH}_{2} \mathrm{Br}$ (with recurrent but minor boronium salt contamination) was also found to completely decompose in solution to the boronium salt, $\left[\mathrm{H}_{2} \mathrm{~B}\left(\mathrm{PHCy}_{2}\right)_{2}\right] \mathrm{Br}$, over a period of 10 minutes at $0^{\circ} \mathrm{C}$.

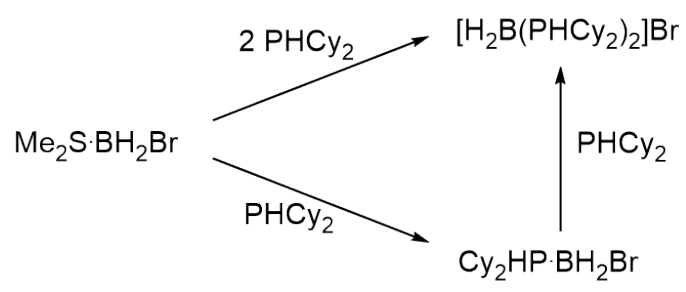

Scheme 2: Synthesis of $\left[\mathrm{H}_{2} \mathrm{~B}(\mathrm{PHCy})_{2}\right] \mathrm{Br}(1)$ via reaction of $\mathrm{BrH}_{2} \mathrm{~B} \cdot \mathrm{PHCY}_{2}$ and $\mathrm{PHCY}_{2}$.

The simple borane adducts $\mathrm{BrH}_{2} \mathrm{~B} \cdot \mathrm{PMe}_{\mathrm{x}} \mathrm{H}_{3-\mathrm{x}}(\mathrm{x}=1-3)$ and their corresponding bis(phosphine) boronium cations $\left[\mathrm{H}_{2} \mathrm{~B}\left(\mathrm{PMe}_{\mathrm{x}} \mathrm{H}_{3-\mathrm{x}}\right)_{2}\right]^{+}$were computationally interrogated (DFT: M06-LACVP) leading to generally unremarkable but reassuring conclusions. Methyl substituents were chosen for computational economy and to obviate steric factors, which nevertheless were later found to play a substantive role. The similarity of both the topologies and energies of the frontier orbitals for the borane adducts $\mathrm{BrH}_{2} \mathrm{~B} \cdot \mathrm{PH}_{\mathrm{x}} \mathrm{Me}_{3-\mathrm{x}}(\mathrm{x}=0,1,2)$ (Error! Reference source not found.) is noteworthy and only those for the primary phosphine adduct are depicted and discussed in detail.

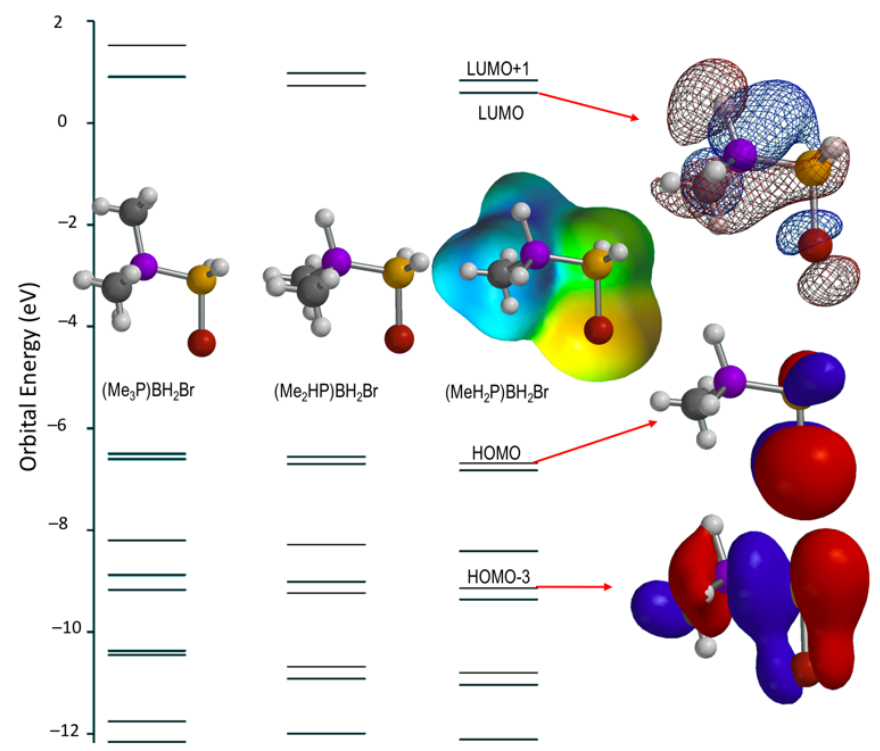

Figure 1: Optimised Geometries and Frontier Orbitals of Interest for $\left(\mathrm{Me}_{x} \mathrm{H}_{3}\right.$. ${ }_{x} \mathrm{P}_{2} \mathrm{BH}_{2} \mathrm{Br}$. Electrostatic ionisation potential surface, HOMO-3, HOMO and LUMO depicted for $\mathrm{x}=1$.

The HOMO, HOMO-1 and HOMO-2 are essentially bromine lone pairs, with HOMO-3 in each case comprising the primary component of the $\mathrm{P} \rightarrow \mathrm{B}$ polar-covalent (dative) bond with modest $p \pi-p \pi B r-B$ conjugation. The energy of this orbital is effectively invariant across the series. The LUMO is spread over much of the molecule, however the regions of interest relate to $\sigma-\mathrm{B}-\mathrm{Br}$ antibonding, opposite the major lobe, consistent with Walden inversion for $S_{N} 2$ reactions in which nucleophiles displace the bromide. This orbital and the LUMO+1 also have considerable $\mathrm{P}-\mathrm{H}$ antibonding character, consistent with 
deprotonation in reactions with (non-nucleophilic) bases. Relative to their constituents $\mathrm{PMe}_{3}, \mathrm{PHMe}_{2}$ and $\mathrm{BH}_{2} \mathrm{Br}$, gas phase thermodynamic data associated with the formation of adducts $\mathrm{Me}_{3} \mathrm{PBH}_{2} \mathrm{Br}\left(\Delta \mathrm{H}=-131.3 \mathrm{kJmol}^{-1}\right)$ and $\mathrm{BrH}_{2} \mathrm{~B} \cdot \mathrm{PHMe}_{2}$ $\left(\Delta \mathrm{H}=-105.1 \mathrm{kJmol}^{-1}\right)$ suggest that the tertiary trialkylphosphine forms a stronger interaction consistent with the increased basicity of tertiary phosphine versus secondary phosphines (e.g., Tolman electronic parameters for $\mathrm{PPh}_{3}$ and $\mathrm{PHPh}_{2}$ are 2068.9 and 2073.3). ${ }^{11}$

The frontier orbitals of all three boronium salts $\left[\mathrm{H}_{2} \mathrm{~B}\left(\mathrm{PMe}_{x} \mathrm{H}_{3-x}\right)_{2}\right]^{+}$comprise closely spaced HOMO/HOMO-1/HOMO-2 set that is almost entirely associated with the $\mathrm{P}_{2} \mathrm{BH}_{2}$ unit $\sigma$-bonding and well-separated from the LUMO by ca $9 \mathrm{eV}$. For all three the similarity of the topology and energies of the frontier orbitals, as discussed above for the borane adducts, was again observed (

Figure 2) such that only those for the simplest $\left[\mathrm{H}_{2} \mathrm{~B}\left(\mathrm{PH}_{2} \mathrm{Me}\right)_{2}\right]^{+}$cation need be discussed.
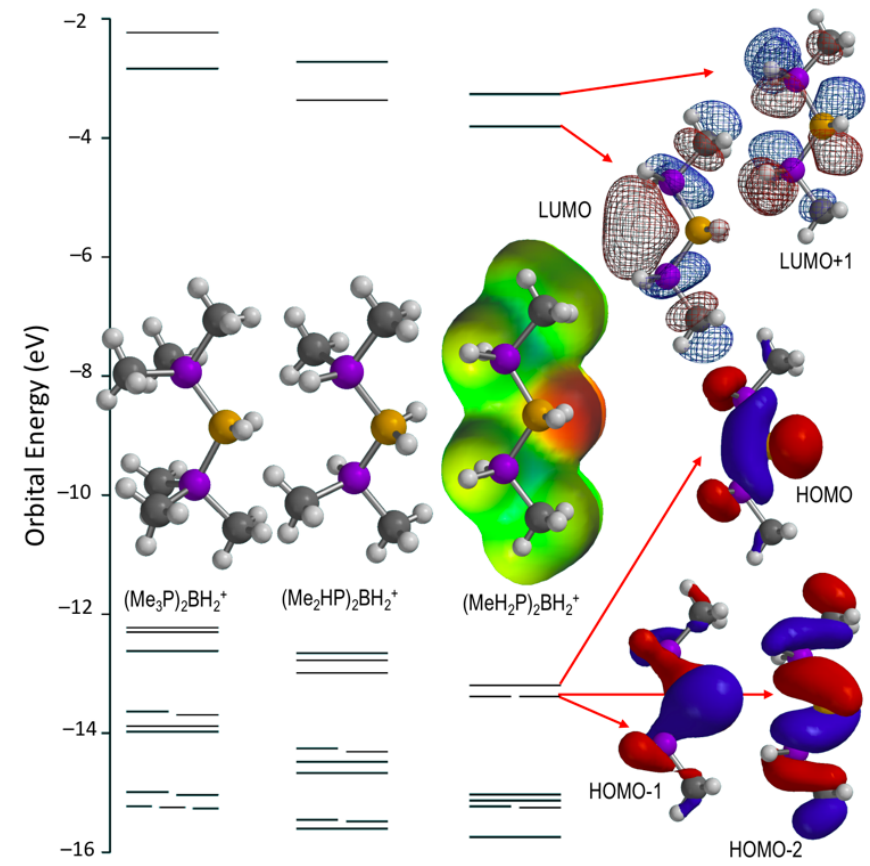

Figure 2: Optimised Geometries and Frontier Orbitals of Interest for $\left[\mathrm{H}_{2} \mathrm{~B}\left(\mathrm{PMe}_{\mathrm{x}} \mathrm{H}_{3}\right.\right.$ $\left.{ }_{x} \mathrm{P}_{2}\right]^{-}$. Electrostatic ionisation potential surface and HOMO-2 to LUMO+1 depicted for $x=1$.

The LUMO is diffused over the entire molecule, comprising some $\mathrm{P}-\mathrm{C} \sigma$-antibonding character but predominantly, concentrated in the region opposite to the borohydride substituents. The LUMO+1, of $\pi$-symmetry in this region has considerable $\mathrm{P}-\mathrm{H}$ $\sigma$-antibonding character, consistent with, e.g., the deprotonation of $\left[\mathrm{H}_{2} \mathrm{~B}\left(\mathrm{PH}_{2} \mathrm{Cy}\right)_{2}\right]^{+}$reported by Weller and Manners. ${ }^{7 i, j}$ Thus reactivity towards both nucleophiles $S_{N} 2$ to LUMO) and deprotonation of phosphorus but not boron (LUMO+1) may be anticipated. Given the majority of boronium salts prepared in this study involved more sterically cumbersome phosphines than $\mathrm{PMe}_{3}$, the comparatively low reactivity towards nucleophiles might be rationalised in terms of steric shielding of this otherwise reactive site. For the secondary phosphine boronium salt, the charges (Mulliken, electrostatic or natural) associated with both $\mathrm{P}$ and $\mathrm{B}$-bound hydrogens was remarkably close to neutral, with the $\mathrm{C}-\mathrm{H}$ bonds being considerably more polarised. These observations taken together with the comparatively large HOMO-LUMO gaps (ca $9.3 \mathrm{eV}$ ) suggest that these salts will be chemically robust.

In both the $\left(\mathrm{Me}_{x} \mathrm{H}_{3-\mathrm{x}} \mathrm{P}\right) \mathrm{BH}_{2} \mathrm{Br}$ and $\left[\mathrm{H}_{2} \mathrm{~B}\left(\mathrm{PMe}_{\mathrm{x}} \mathrm{H}_{3-\mathrm{x}}\right)_{2}\right]+$ series, the localisation of HOMO-n $(n=0,1,2)$ around the $\mathrm{BH}_{2}$ unit indicates the retention of 'hydridic' character for the $\mathrm{B}-\mathrm{H}$ bonds, which is to some extent ameliorated by the positive charge in the boronium series.

Whilst the formation of $\left[\mathrm{H}_{2} \mathrm{~B}\left(\mathrm{PHCy}_{2}\right)_{2}\right] \mathrm{Br}$ readily occurred, the reaction of $\mathrm{BrH}_{2} \mathrm{~B} \cdot \mathrm{SMe}_{2}$ with two equivalents of $\mathrm{PCy}_{3}$ failed to produce the boronium salt $\left[\mathrm{H}_{2} \mathrm{~B}\left(\mathrm{PC} y_{3}\right)_{2}\right] \mathrm{Br}$, being consistent with previous observations of the inability to isolate $\left[\mathrm{H}_{2} \mathrm{~B}\left(\mathrm{PPh}_{3}\right)_{2}\right] \mathrm{Br}$ by reaction of $\mathrm{BrH}_{2} \mathrm{~B} \cdot \mathrm{SMe}_{2}$ with two equivalents of $\mathrm{PPh}_{3} .{ }^{8 \mathrm{C}}$ In these cases, the reaction only proceeded as far as the corresponding phosphine-stabilised mixed haloborane species $\mathrm{R}_{3} \mathrm{PBH}_{2} \mathrm{Br}(\mathrm{R}=\mathrm{Ph}, \mathrm{Cy})$. In steric terms, the tertiary phosphine $\mathrm{PMe}_{2} \mathrm{Ph}$ was found to be the limit so far as accessing a (non-chelated) bis(phosphonio) ligated boronium species, whereupon reaction of two equivalents of $\mathrm{PMe}_{2} \mathrm{Ph}$ and $\mathrm{BrH}_{2} \mathrm{~B} \cdot \mathrm{SMe}_{2}$ cleanly yielded the associated boronium salt $\left[\mathrm{H}_{2} \mathrm{~B}\left(\mathrm{PMe}{ }_{2} \mathrm{Ph}\right)_{2}\right] \mathrm{Br}(4)^{+}$in $85 \%$ yield.

As previously discussed (vide supra), $\mathbf{1}$ is formed by reaction of $\mathrm{BrH}_{2} \mathrm{~B} \cdot \mathrm{SMe}_{2}$ and $\mathrm{PHCy}_{2}$ regardless of stoichiometry. However, the intermediate formation of mono(phosphine)bromoboranes raised the question of sequentially introducing two different phosphines to obtain heteroleptic examples. Several combinations of the bromoborane adducts and extraneous phosphines were explored (Table 1).

\begin{tabular}{|c|l|l|}
\hline Combination & $\mathrm{BrH}_{\mathbf{2}} \mathbf{B} \cdot \mathbf{P R}_{\mathbf{3}}$ & \multicolumn{1}{l|}{$\mathbf{P R}_{\mathbf{3}}$} \\
\hline A & $\mathrm{BrH}_{2} \mathrm{~B} \cdot \mathrm{PPh}_{3}$ & $\mathrm{PHCy}_{2}$ \\
\hline B & $\mathrm{BrH}_{2} \mathrm{~B} \cdot \mathrm{PPh}_{3}$ & $\mathrm{PHPh}_{2}$ \\
\hline C & $\mathrm{BrH}_{2} \mathrm{~B} \cdot \mathrm{PCy}_{3}$ & $\mathrm{PH}_{2} \mathrm{Cy}$ \\
\hline D & $\mathrm{BrH}_{2} \mathrm{~B} \cdot \mathrm{PHCy}_{2}$ & $\mathrm{PH}_{2} \mathrm{Cy}$ \\
\hline E & $\mathrm{BrH}_{2} \mathrm{~B} \cdot \mathrm{PHCy}_{2}$ & $\mathrm{PHPh}_{2}$ \\
\hline
\end{tabular}

Table 1: Combinations of phosphine-stabilised monobromoboranes and phosphines investigated en route to unsymmetrical boronium salts.

Notably, in all cases (combinations A-E), the symmetrically substituted boronium salts were preferentially formed. For highly nucleophilic phosphines (Combination $\mathbf{D}$ and $\mathbf{E}$ ), this might be accounted for by the rate of the second substitution being too rapid to allow sequential introduction. However, initial formation of the stable, albeit sterically congested tertiary phosphine adducts, $\mathrm{R}_{3} \mathrm{PBH}_{2} \mathrm{Br}(\mathrm{R}=\mathrm{Ph}, \mathrm{Cy})$, followed by addition of a primary or secondary phosphine (combinations $A$ C) still led to the isolation of the symmetrical primary or secondary phosphine boronium salt and half an equivalent of tertiary phosphine adduct.

By cooling the reaction of combination $D$ to $-78^{\circ} \mathrm{C}$, a small amount of the unsymmetrical boronium salt $\left[\mathrm{H}_{2} \mathrm{~B}\left(\mathrm{PHCy}_{2}\right)\left(\mathrm{PH}_{2} \mathrm{Cy}\right)\right] \mathrm{Br}$ (5) was observed by $\mathrm{NMR}$ analysis. Specifically, the ${ }^{31} \mathrm{P}\left\{{ }^{1} \mathrm{H}\right\}$ NMR spectrum included a broadened AB system $\left(\delta_{\mathrm{P}}-41.6,0.4,2 J_{\mathrm{AB}} 72.5 \mathrm{~Hz} ; c f . \delta_{\mathrm{P}}-38.6\right.$ for $\left[\mathrm{H}_{2} \mathrm{~B}\left(\mathrm{PH}_{2} \mathrm{Cy}\right)_{2}\right] \mathrm{Br}$ and $\delta_{\mathrm{P}}-1.2$ for $\left.\left[\mathrm{H}_{2} \mathrm{~B}(\mathrm{PHCy})_{2}\right] \mathrm{Br}\right)$. A resonance was observed in the ${ }^{11} \mathrm{~B}$ NMR spectrum $\left(\delta_{B}-45.1\right)$ which was 
effectively unchanged compared to either of the two symmetrical boronium salts ( $c f . \delta_{B}-44.5$ for $\left[\mathrm{H}_{2} \mathrm{~B}\left(\mathrm{PH}_{2} \mathrm{Cy}\right)_{2}\right] \mathrm{Br}$ and $\delta_{B}-45.2$ for $\left.\left[\mathrm{H}_{2} \mathrm{~B}\left(\mathrm{PHCy}_{2}\right)_{2}\right] \mathrm{Br}\right)$, i.e., given the half-height widths of these resonances, the chemical shift is not usefully diagnostic.

The product was, however, found to fully disproportionate to its two respective symmetrical boronium salts, $\left[\mathrm{H}_{2} \mathrm{~B}\left(\mathrm{PH}_{2} \mathrm{Cy}\right)_{2}\right] \mathrm{Br}$ and $\left[\mathrm{H}_{2} \mathrm{~B}(\mathrm{PHCy})_{2}\right] \mathrm{Br}$, after a short period of time ( $c a 30 \mathrm{~min}$ at room temperature), confounding isolation for further study. The reaction of combination $\mathbf{E}$ at $0^{\circ} \mathrm{C}$ also produced the desired product, $\left[\mathrm{H}_{2} \mathrm{~B}\left(\mathrm{PHCy}_{2}\right)\left(\mathrm{PHPh}_{2}\right)\right] \mathrm{Br}\left(6 ; \delta_{\mathrm{P}}-\right.$ $21.2,-3.2,{ }^{2} J_{A B} 261.5 \mathrm{~Hz} ; c f . \delta_{\mathrm{P}}-16.2$ for $\left[\mathrm{H}_{2} \mathrm{~B}\left(\mathrm{PHPh}_{2}\right)_{2}\right] \mathrm{Br}$ and $\delta_{\mathrm{P}}$ -1.2 for $\left[\mathrm{H}_{2} \mathrm{~B}(\mathrm{PHCy})_{2}\right] \mathrm{Br}$ ), but once again this was found to completely disproportionate during work-up to the two respective symmetrical boronium salts, $\left[\mathrm{H}_{2} \mathrm{~B}\left(\mathrm{PHCy}_{2}\right)_{2}\right] \mathrm{Br}$ and $\left[\mathrm{H}_{2} \mathrm{~B}\left(\mathrm{PHPh}_{2}\right)_{2}\right] \mathrm{Br}$, eliminating it as a viable target for further studies.

The modification of acyclic secondary phosphine boronium salts often resulted in the liberation of free secondary phosphine. Presuming chelation might confer some degree of kinetic stabilisation, a series of cyclic boronium salts were investigated, $\quad f . \quad\left[\mathrm{H}_{2} \mathrm{~B}(\mathrm{dppe})\right] \mathrm{Br} \quad(7 ; \quad$ dppe $=1,2-$ bis(diphenylphosphino)ethane) reported previously by Schmidbaur. ${ }^{8}$ The new cyclic boronium salt $\left[\mathrm{H}_{2} \mathrm{~B}(\mathrm{dcpe})\right]\left[\mathrm{BHBr}_{3}\right]$ (8) readily formed upon reaction of $\mathrm{BrH}_{2} \mathrm{~B} \cdot \mathrm{SMe}_{2}$ and dcpe (1,2bis(dicyclohexylphosphino)ethane) in $71 \%$ yield (based on dcpe). The product was unusually isolated as the $\left[\mathrm{BHBr}_{3}\right]^{-}$salt rather than the simple bromide. The tribromoborate anion presumably arises from the reaction of the liberated bromide with a second equivalent of haloborane, which would need to be $\mathrm{Br}_{2} \mathrm{HB} \cdot \mathrm{SMe}_{2}$, itself most likely generated from disproportionation of the $\mathrm{BrH}_{2} \mathrm{~B} \cdot \mathrm{SMe}_{2} .{ }^{*}$ Whilst the $\left[\mathrm{BHBr}_{3}\right]^{-}$anion might appear simple, it has only been encountered on two previous instances from reactions of polyboronate salts $\left[\mathrm{NR}_{4}\right]\left[\mathrm{B}_{x} \mathrm{H}_{\mathrm{y}}\right]\left(\mathrm{R}=\mathrm{Me},{ }^{n} \mathrm{Bu} ; \mathrm{x} / \mathrm{y}=1 / 4,3 / 8,4 / 9\right.$, 9/14) with $\mathrm{BBr}_{3}$ and characterised on the basis of its ${ }^{11} \mathrm{~B} N M R$ data $\left(\delta_{\mathrm{B}}-13.1,{ }^{1} \mathrm{~B}_{\mathrm{BH}}=175 \mathrm{~Hz}\right)$ alone. ${ }^{12}$ The salt 8 therefore provides the first structural data for this anion, which adopts a near tetrahedral geometry ( $\mathrm{Br}-\mathrm{B}-\mathrm{Br}$ angles in the conventional range 107.6 to $110.6^{\circ}$ ) that is surprisingly devoid of any significant distortions arising from the disparity in the size of the $\mathrm{Br}$ vs $\mathrm{H}$ substituents. The BPCCP heterocycle is slightly nonplanar, i.e. chiral (space group $P 2_{1} / n, \delta / \lambda$ enantiomers generated by crystallographic symmetry), with a slightly contracted P1-B1-P2 angle of $101.2(2)^{\circ}$ reflecting the constraints of chelation.

The permethylated analogue, $\left[\mathrm{H}_{2} \mathrm{~B}(\mathrm{dmpe})\right] \mathrm{Br}$ (9) (dmpe = 1,2-bis(dimethylphosphino)ethane), was also readily prepared by reaction of $\mathrm{BrH}_{2} \mathrm{~B} \cdot \mathrm{SMe}_{2}$ with dmpe in $73 \%$ yield. However, unlike the dppe and dcpe analogues, the dmpe boronium salt was found to be insoluble in most common solvents. Partial solubility in $d_{6}$-DMSO or $\mathrm{D}_{2} \mathrm{O}$ allowed limited spectroscopic data to be acquired $\left({ }^{1} \mathrm{H},{ }^{11} \mathrm{~B}\right.$ and ${ }^{31} \mathrm{P}$ but not ${ }^{13} \mathrm{C}$ NMR data), however, neither proved suitable for growing crystallographic grade crystals. The monomeric rather than polymeric nature of the salt was nevertheless confirmed conclusively by microanalysis, +ve ion ESI mass spectroscopy and NMR spectroscopy. The satisfactory elemental microanalytical data confirmed the presence of a single equivalent of $\mathrm{BH}_{2} \mathrm{Br}$ to the dmpe, whilst the single peak in the ESI-MS $(m / z$ 163.1) matched precisely the isotopic array of the desired product. The ${ }^{11} \mathrm{~B} N M R$ peak $\left(\delta_{\mathrm{B}}-34.5\right)$ appeared in a similar region to that observed for $\left[\mathrm{H}_{2} \mathrm{~B}\right.$ (dppe) $] \mathrm{Br}\left(\delta_{\mathrm{B}}-35.7\right)$ by Schmidbaur and coworkers, ${ }^{9}$ indicating that the chemical shift is somewhat insensitive to the disparate donor abilities of the two diphosphines.

An alternative order for the introduction of a boronium centre was considered involving reactions of $\mathrm{BrH}_{2} \mathrm{~B} \cdot \mathrm{SMe}_{2}$ with phosphine groups already bound to a metal centre, e.g., 1,1'bis(diphenylphosphino)ferrocene (dppf). The disubstituted $\mathrm{BH}_{3}$ complex had been previously reported and was found to be air stable, ${ }^{13}$ suggesting that the analogous use of $\mathrm{BrH}_{2} \mathrm{~B} \cdot \mathrm{SMe}_{2}$ should proceed without issue. Formation of the desired dppf boronium salt, $\left[\mathrm{H}_{2} \mathrm{~B}(\mathrm{dppf})\right] \mathrm{Br}(\mathbf{1 0})$, seemed plausible given the extensive chelate chemistry of this ligand with transition metals, e.g., $\mathrm{PdCl}_{2}$ (dppf) and $\mathrm{PtCl}_{2}$ (dppf). ${ }^{14}$ The possibility of a direct interaction between the iron centre and the boron was also considered given that Seyferth has described a dative bond between iron and palladium in the complex $\operatorname{FePd}(\mu-$ $\left.\mathrm{C}_{5} \mathrm{H}_{4} \mathrm{~S}\right)_{2}\left(\mathrm{PPh}_{3}\right)$ (

Figure 3). ${ }^{15}$

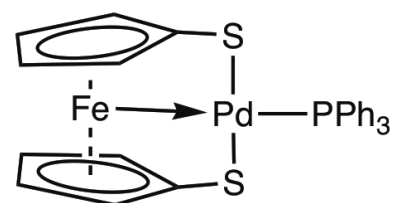

Figure 3: The structure of $\mathrm{Pd}\left(\mathrm{PPh}_{3}\right)\left\{\left(\mathrm{SC}_{5} \mathrm{H}_{4}\right)_{2} \mathrm{Fe}\right\}$ featuring an iron-palladium dative bond. ${ }^{15}$

The reaction of equimolar amounts of dppf with $\mathrm{BrH}_{2} \mathrm{~B} \cdot \mathrm{SMe}_{2}$ was found to simply form the mono-substituted species, $\mathrm{BrH}_{2} \mathrm{~B} \cdot \mathrm{dppf}$, which was observed to display the aforementioned characteristic phosphine-stabilised $\mathrm{BH}_{2} \mathrm{Br}$ shift of $-24.1 \mathrm{ppm}$ in the ${ }^{11} \mathrm{~B}\left\{{ }^{1} \mathrm{H}\right\}$ NMR spectrum. However, when the reaction mixture was heated to reflux in toluene for 18 hours, a pale orange precipitate was observed to form. The pale orange precipitate had a single resonance at $-27.4 \mathrm{ppm}$ in the ${ }^{11} \mathrm{~B}\left\{{ }^{1} \mathrm{H}\right\}$ NMR spectrum, consistent with the desired ferrocenophane boronium salt 10 . The ${ }^{31} \mathrm{P}\left\{{ }^{1} \mathrm{H}\right\}$ NMR spectrum was found to contain only one resonance at $9.7 \mathrm{ppm}$, which was discernibly shifted to higher frequency in comparison to both the resonances for the mono-substituted dppf. $\mathrm{BH}_{2} \mathrm{Br}\left(\delta_{\mathrm{P}}-16.7,1.8\right.$ for the free $\mathrm{PPh}_{2}$ and boron-coordinated $\mathrm{PPh}_{2}$ groups, respectively). Unusually, the ${ }^{1} \mathrm{H}$ NMR spectrum was very broad for all resonances, suggesting some form of fluxionality. Geometry optimisation of the ferrocenophane boronium salt indicates that the $\mathrm{BH}_{2}$ group lies above the plane defined by the two P-C bonds between phosphorus and ferrocene (Figure 4). Inversion of this geometry would account for the broadness of the ${ }^{1} \mathrm{H}$ NMR spectrum, as has been shown for the trithiaferrocenophane $\mathrm{Fe}\left\{\mathrm{S}_{3}\left(\mathrm{C}_{5} \mathrm{H}_{4}\right)_{2}\right\} .{ }^{16}$ 


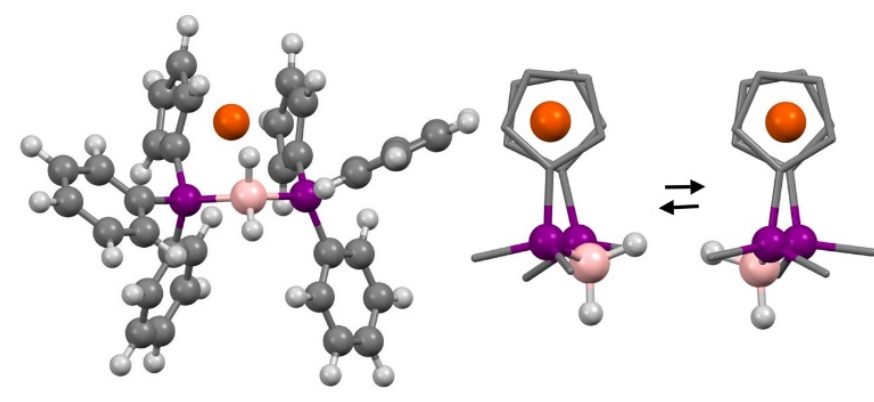

Figure 4: The geometry optimized structure of the ferrocenophane boronium cation $\left[\mathrm{H}_{2} \mathrm{~B}(\mathrm{dppf})\right]^{+}$of $\mathbf{1 0}$ and the potential inversion of its geometry.

Compound $\mathbf{1 0}$ was found to be thermodynamically unstable and decomposes as a solid back to dppf over 24 hours. Substitution of the bromide counterion for $\left[\mathrm{AsF}_{6}\right]^{-}(\mathbf{1 1}$; Figure 5) was found to provide a material that is stable under an inert atmosphere. An unusual minor side-product of the anion metathesis was found to be the salt $\left[\mathrm{H}_{2} \mathrm{~B}(\mathrm{dppf})\right]\left[\mathrm{FeBr}_{4}\right]$ (Figure $5)$, arising from degradation of the dppf backbone which had not been observed during the initial synthesis of $\mathbf{1 0}$.

The inclusion of lighter pnictogens was found to provide the most effective heterodentate ligands, and interestingly, chelated boronium cations based on a $P, N$ donor set have yet to be explored. The heterotopic ligand $\mathrm{N}, \mathrm{N}$-dimethyl-2(diphenylphosphino)aniline (amphos) presents both amine and phosphine donors in a rigid geometry predisposed towards chelation. The reaction of amphos with $\mathrm{BrH}_{2} \mathrm{~B} \cdot \mathrm{SMe}_{2}$ was found to readily proceed to the boronium salt $\left[\mathrm{H}_{2} \mathrm{~B}\right.$ (amphos) $] \mathrm{Br}$ (12) in $93 \%$ yield. Despite the stronger $\sigma$-donation of the $\mathrm{NMe}_{2}$ group in comparison to a $\mathrm{PPh}_{2}$ group, the ${ }^{11} \mathrm{~B}$ NMR resonance observed $(-9.3 \mathrm{ppm})$ was found to be to significantly higher frequency than that of $\left[\mathrm{H}_{2} \mathrm{~B}(\mathrm{dppph})\right] \mathrm{Br}\left(\delta_{\mathrm{B}}-32.9\right.$; dppph $=1,2-$ bis(diphenylphosphino)benzene). ${ }^{8 \mathrm{~g}}$ The solid-state structure of 12 revealed that the $\mathrm{BH}_{2}$ substituent was displaced from the P1-C1-C2-N1 plane by $0.49 \AA$ A, but interestingly the P-B bond length of $1.947(2) \AA$ was crystallographically indistinguishable from both of those in $\left[\mathrm{H}_{2} \mathrm{~B}(\mathrm{dppph})\right] \mathrm{Br}$ (cf. $\mathrm{P}-\mathrm{B}=1.939(5)$, 1.941(5) $\AA$ ), ${ }^{8 g}$ despite the replacement of $\mathrm{NMe}_{2}$ by $\mathrm{PPh}_{2}$.

Schmidbaur et al. have reported the use of $\mathrm{Br}_{2} \mathrm{HB} \cdot \mathrm{SMe}_{2}$ to synthesise boronium salts bearing a $\mathrm{BHBr}$ group by reaction with two equivalents of $\mathrm{PMe}_{3}$ or $\mathrm{PEt}_{3}$, via the same process of bromide ionisation. ${ }^{8} \mathrm{~A} \mathrm{BHBr}$ group was seen as a more versatile functionality than a $\mathrm{BH}_{2}$ substituent, offering the possibility of nucleophilic substitution. Despite the reported failure of dppe to react with $\mathrm{Br}_{2} \mathrm{HB} \cdot \mathrm{SMe}_{2}$ to form $[\mathrm{BrHB}(\mathrm{dppe})] \mathrm{Br}$, the analogous reaction of the far more basic dcpe with $\mathrm{Br}_{2} \mathrm{HB} \cdot \mathrm{SMe}_{2}$ was explored and found to provide the desired $\mathrm{BHBr}$ boronium salt $[\mathrm{BrHB}$ (dcpe) $] \mathrm{Br}$ (13). The salt eluded isolation in bulk purity due to the difficulties in separating it from the acyclic adduct dcpe $\left(\mathrm{BHBr}_{2}\right)_{2}$ by any other method than manual crystal picking. The presence of both 13 and dcpe· $\left(\mathrm{BHBr}_{2}\right)_{2}$ were, however, confirmed spectroscopically and crystallographically (Figure 6).

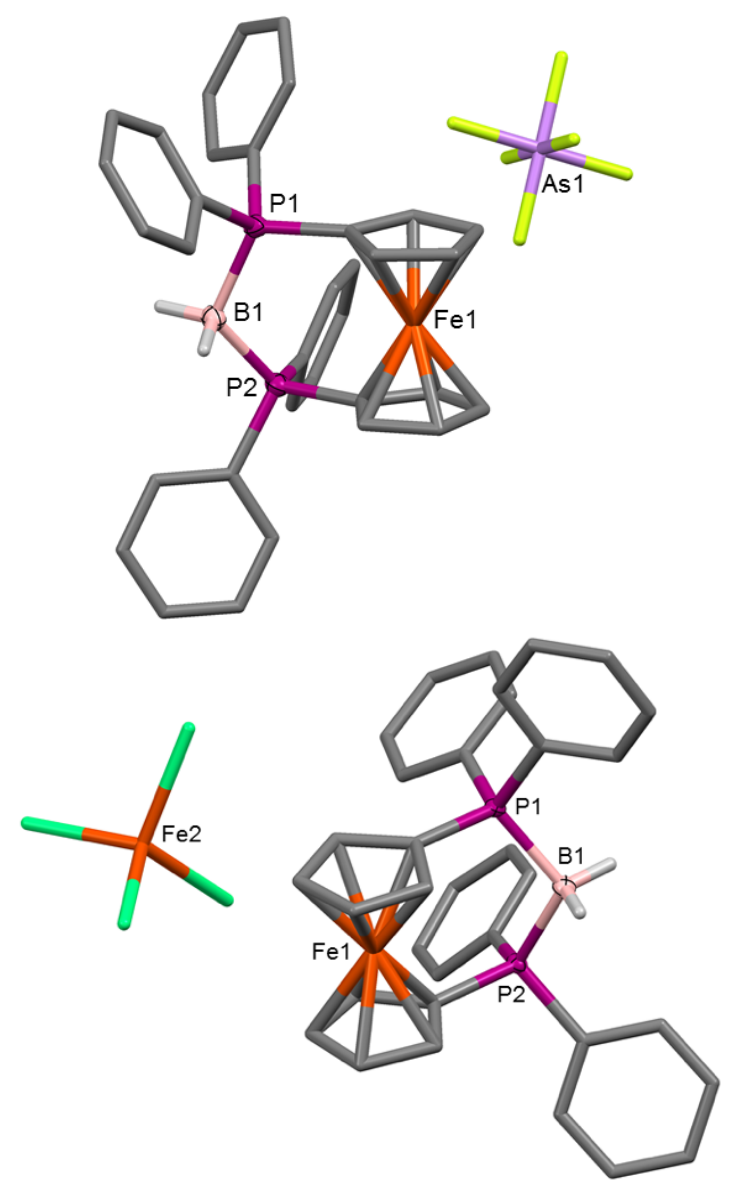

Figure 5: The molecular structure of $\left[\mathrm{H}_{2} \mathrm{~B}(\mathrm{dppf})\right]\left[\mathrm{AsF}_{6}\right](\mathbf{1 1} ;$ above $)$ and $\left[\mathrm{H}_{2} \mathrm{~B}(\mathrm{dppf})\right]\left[\mathrm{FeBr}_{4}\right]$ (below). (Alkyl hydrogen atoms omitted for clarity, ferrocenyl, anions and phenyl groups simplified, 50\% displacement ellipsoids). Selected bond lengths $(\AA ̊)$, angles $\left({ }^{\circ}\right)$ and intramolecular distances $(\AA)$ for 11: B1-P1 1.934(2); B1-P2 1.924(2); P1-C1 1.800(1); P2-C6 1.785(1); P1-B1-P2 117.92(9); B1-P1-C1 115.83(7); B1-P2-C6 111.47(8); Fe1-C1-P1 123.06(8); Fe1-C6-P2 123.75(8); Fe1...B1 3.766(2). Selected bond lengths $(\AA \AA)$, angles $\left({ }^{\circ}\right)$ and intramolecular distances (Å) for $\left[\mathrm{H}_{2} \mathrm{~B}(\mathrm{dppf})\right]\left[\mathrm{FeBr}_{4}\right]$ : B1-P1 1.923(3); B1-P2 1.926(3); P1-C1 1.789(3); P2-C6 1.795(3); P1-B1-P2 112.6(2); B1-P1-C1 112.0(1); B1-P2-C6 112.7(1); Fe1-C1-P1 123.2(1); Fe1-C6-P2 123.7(1); Fe1...B1 3.729(3).

When the reaction was carried out at room temperature in benzene, the two products were found to form in near equal amounts, as determined by ${ }^{31} \mathrm{P}\left\{{ }^{1} \mathrm{H}\right\}$ NMR integration. The boronium salt 13 was observed at $\delta_{\mathrm{B}}-26.8$ and $\delta_{\mathrm{p}}-20.9$, whilst the adduct dcpe-( $\left(\mathrm{BHBr}_{2}\right)_{2}$ was apparent at $\delta_{\mathrm{B}}-17.6$ and $\delta_{\mathrm{P}} 0.1$, along with some unreacted dcpe that was removed upon workup. The two products, though not separately isolated in bulk quantities, were formulated based on solid-state crystal structure determinations and the trends observed for previously synthesised analogous compounds. Despite bromine being a potential hydrogen bond acceptor, examination of the solid-state structure of $\mathbf{1 3}$ revealed no obvious intermolecular interactions of note between the boron-coordinated bromine and anything else, as might have been expected due to the steric hindrance caused by the surrounding cyclohexyl substituents. Interestingly, manually picked crystals of dcpe. $\left(\mathrm{BHBr}_{2}\right)_{2}$, the identity of which was confirmed crystallographically, were found upon dissolution to provide equimolar amounts of $\mathbf{1 3}$ also present in the ${ }^{11} \mathrm{~B}$ and ${ }^{31 P} \mathrm{PMR}$ spectra. This observation did not change over time, suggesting 
that the two species existed in equilibrium with one another in DCM, and was supported by the consistency with which the two products were always observed together spectroscopically.

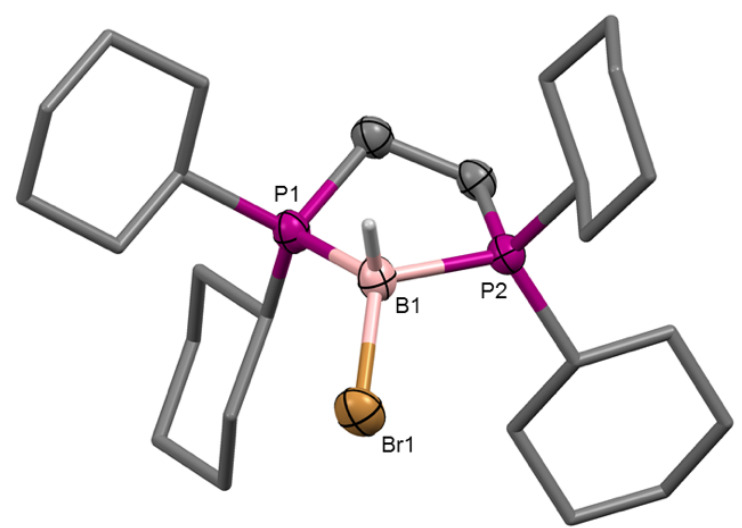

Figure 6: The molecular structure of $[\mathrm{BrHB}(\mathrm{dcpe})] \mathrm{Br}$ (13). (Bromide and alkyl hydrogen atoms omitted for clarity, cyclohexyl groups simplified, $50 \%$ displacement ellipsoids). Selected bond lengths $(\AA)$ and angles $\left({ }^{\circ}\right)$ : B1-Br1 2.013(4); B1-P1 1.955(4); B1-P2 1.960(4); Br1-B1-P1 121.8(2); Br1-B1-P2 114.8(2); P1-B1-P2 101.0(2).

The successful synthesis of $\mathbf{1 3}$ confirmed that strongly $\sigma$ basic chelating phosphines would favour the formation of $B$ bromo boronium salts and accordingly, basic monodentate phosphines were next considered. In contrast to dcpe, however, the reaction of $\mathrm{Br}_{2} \mathrm{HB} \cdot \mathrm{SMe}_{2}$ with two equivalents of $\mathrm{PHCy}_{2}$ was found to provide the phosphine-borane adduct $\mathrm{Br}_{2} \mathrm{HB} \cdot \mathrm{PHCy}{ }_{2}\left(\delta_{\mathrm{B}}\right.$ $\left.-18.7 ; \delta_{\mathrm{p}} 0.6\right)$, but not the boronium salt $\left[\mathrm{BrHB}\left(\mathrm{PHCy}_{2}\right)_{2}\right] \mathrm{Br}$. A very minor second product was observed in the ${ }^{11} \mathrm{~B}\left\{{ }^{1} \mathrm{H}\right\} \mathrm{NMR}$ spectrum at $-45.2 \mathrm{ppm}$, attributable to $\left[\mathrm{H}_{2} \mathrm{~B}(\mathrm{PHCy})_{2}\right] \mathrm{Br}$ (1), arising from disproportionation of the $\mathrm{Br}_{2} \mathrm{HB} \cdot \mathrm{SMe}_{2}$ starting material to $\mathrm{BrH}_{2} \mathrm{~B} \cdot \mathrm{SMe}_{2}$. Attempted isolation of $\mathrm{Br}_{2} \mathrm{HB} \cdot \mathrm{PHCy}{ }_{2}$ resulted in its decomposition to the phosphonium salt $\left[\mathrm{PH}_{2} \mathrm{Cy}_{2}\right] \mathrm{Br}$, the cation of which had been previously observed when the $\mathrm{Cl}_{2} \mathrm{HB} \cdot \mathrm{PHCy}_{2}$ adduct similarly decomposed to $\left[\mathrm{PH}_{2} \mathrm{Cy}_{2}\right]\left[\mathrm{HCl}_{2}\right]$. The bichloride anion, $\left[\mathrm{HCl}_{2}\right]^{-}$, was an unusual counter-ion and one that has relatively few prior solid-state examples. ${ }^{21}$ The geometric parameters of $\left[\mathrm{HCl}_{2}\right]^{-}$are, however, indistinguishable from those previously reported for other salts containing this anion and therefore call for no further comment.

The recovery of phosphonium salts from reactions of Lewis bases with $\mathrm{BrH}_{2} \mathrm{~B} \cdot \mathrm{SMe}_{2}, \mathrm{Br}_{2} \mathrm{HB} \cdot \mathrm{SMe}_{2}$ or $\mathrm{BBr}_{3}$ was a recurrent feature observed in this chemistry. Secondary phosphines produced phosphonium salts upon reaction with $\mathrm{Br}_{2} \mathrm{HB} \cdot \mathrm{SMe}_{2}$, whilst tertiary phosphines provided simple phosphinestabilised dibromoborane adducts. This dichotomy might reflect steric or electronic control and accordingly, smaller but strongly $\sigma$-basic tertiary phosphines were next investigated given that $\mathbf{4}$ had been previously isolated. The reaction of two equivalents of $\mathrm{PMe}_{2} \mathrm{Ph}$ with $\mathrm{Br}_{2} \mathrm{HB} \cdot \mathrm{SMe}_{2}$ in pentane was found to proceed to the desired bromoboronium salt $\left[\mathrm{BrHB}\left(\mathrm{PMe} \mathrm{PMh}_{2}\right] \mathrm{Br}\left(\mathbf{1 4} ; \delta_{\mathrm{B}}-\right.\right.$ $\left.21.5, \delta_{\mathrm{P}}-7.5\right)$. The crude product was found to form an oil of reasonable purity, though attempts at further purification led to extensive decomposition. Electrospray MS (+ve ion) analysis further corroborated the identity of the product with an appropriate isotopic envelope at $\mathrm{m} / \mathrm{z}=367.1$ and 369.1, confirming bromine inclusion in the cation. Conducting the reaction in dichloromethane was found to only partially proceed to $\left[\mathrm{BrHB}\left(\mathrm{PMe}_{2} \mathrm{Ph}\right)_{2}\right] \mathrm{Br}$, with the majority of the crude reaction mixture comprising the adduct $\mathrm{Br}_{2} \mathrm{HB} \cdot \mathrm{PMe}{ }_{2} \mathrm{Ph}\left(\delta_{\mathrm{B}}-\right.$ 15.6, $\left.\delta_{\mathrm{P}}-12.1\right)$. It would therefore seem that the formation of the boronium salt in pentane is driven by its precipitation, whilst in solution it readily reverts to the neutral adduct. Conducting the reaction in benzene (another solvent from which salt precipitation might be expected to occur) failed to generate appreciable amounts of the boronium salt, whilst heating $\left(75^{\circ} \mathrm{C}\right.$, 3 hours) resulted in eventual formation of the phosphonium salt $\left[\mathrm{PHMe}_{2} \mathrm{Ph}\right] \mathrm{Br}$ which precipitated from the benzene solution upon formation.

The rigid phenylene backbone coupled with the strong $\sigma$ basicity of the $\mathrm{NMe}_{2}$ group in $\mathrm{Me}_{2} \mathrm{NC}_{6} \mathrm{H}_{4} \mathrm{PPh}_{2}-2$ (amphos) made it a promising candidate for the formation of monobromoboronium salts. The reaction between $\mathrm{Br}_{2} \mathrm{HB} \cdot \mathrm{SMe}_{2}$ and amphos proceeded cleanly to the desired boronium product [ $\mathrm{BrHB}$ (amphos)] $\mathrm{Br}$ (15; Figure 7). An NMR analysis of the product revealed resonances at $\delta_{\mathrm{B}}-5.2$ and $\delta_{\mathrm{P}}-11.0$, along with inequivalent resonances for the diastereotopic methyl groups of the tertiary amine $\left(\delta_{H} 3.24,3.77\right)$ adjacent to the chiral boron centre.

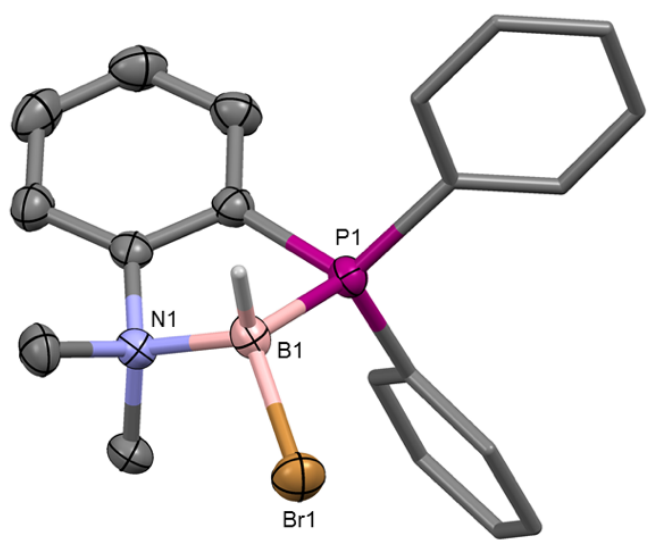

Figure 7: The molecular structure of one enantiomer of [ $\mathrm{BrHB}$ (amphos)] $\mathrm{Br}$ (15). (Alternative enantiomer generated by crystallographic $P 2_{1} /$ a symmetry; bromide, solvate molecules and alkyl hydrogen atoms omitted for clarity, phenyl rings simplified, $50 \%$ displacement ellipsoids). Selected bond lengths $(\AA)$ and angles $\left({ }^{\circ}\right)$ : B1-Br1 1.980(4); B1-N1 1.621(3); B1-P1 1.947(2); Br1-B1-N1 113.4(2); Br1-B1-P1 116.6(2); N1-B1-P1 101.1(1).

The solid-state structure revealed that the boron atom of [BrHB(amphos)] Br is displaced from the $\mathrm{P} 1-\mathrm{C} 1-\mathrm{C} 2-\mathrm{N} 1$ plane more significantly $\left(37.3^{\circ}\right)$ than was found for $\left[\mathrm{H}_{2} \mathrm{~B}\right.$ (amphos) $] \mathrm{Br}$ $\left(25.8^{\circ}\right)$, due to replacement of a hydrogen atom with the sterically more demanding bromine substituent, which assumes a pseudo-equatorial position with respect to the $\mathrm{C}_{2} \mathrm{NPB}$ heterocycle. The centrosymmetric $P 2_{1}$ /a space group adopted by $r a c-[\mathrm{BrHB}(\mathrm{amphos})] \mathrm{Br}$ accommodates both enantiomers (Figure 8). 


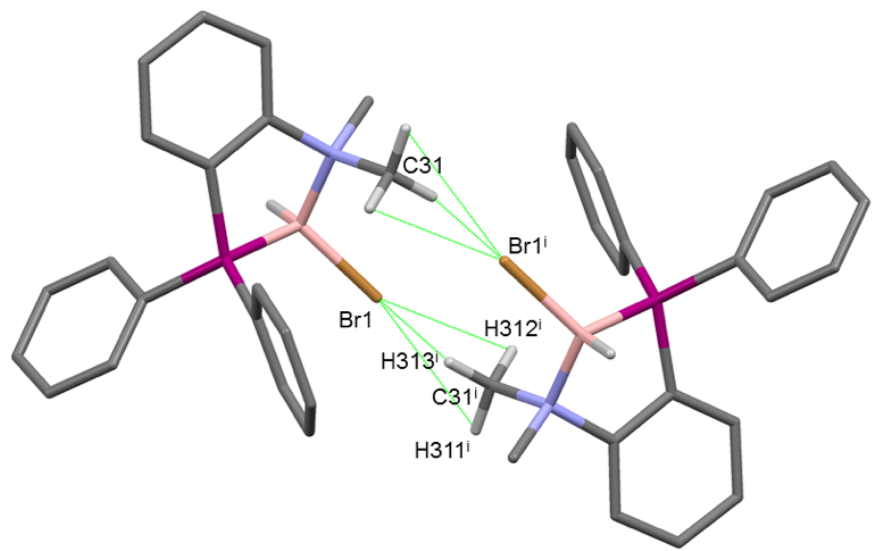

Figure 8: The molecular packing of two enantiomeric $[\mathrm{BrHB}(\mathrm{amphos})]^{+}$cations of 15. Selected intermolecular distances ( $\AA$ ): $\mathrm{Br} 1-\mathrm{H} 311^{i} 3.4827$; $\mathrm{Br} 1-\mathrm{H} 312^{i} 3.0870$ $\mathrm{Br} 1-\mathrm{H} 313^{\mathrm{i}} 3.2283$.

The crystallographic packing of rac-[BrHB(amphos)] $\mathrm{Br}$ was of interest as it clearly displayed a dimer type arrangement bridged by trifurcated $\mathrm{C}-\mathrm{H} \cdots \mathrm{Br}$ hydrogen bonding between $\mathrm{N}-\mathrm{CH}_{3}$ and $\mathrm{Br}$ groups on adjacent enantiomeric cations (Figure 8). The chiral $\mathrm{H}, \mathrm{Br}, \mathrm{P}, \mathrm{N}$ donor set of the boronium cation is without precedent in the literature. Compound $\mathbf{1 5}$ also has features that differ from its diphosphine counterparts. The higher frequency ${ }^{11} \mathrm{~B}$ NMR peak indicates a more deshielded boron environment, which might be reflected in enhanced reactivity, coupled with far less steric protection provided by the much smaller methyl groups of the amine.

The approach of using heterotopic chelates to selectively bind boron-based groups, whilst leaving other donor groups free for further synthesis, was seen as a viable method in the context of boronium salt formation bearing additional pendant donor groups. The potentially tetradentate ligand, meso-1,2bis(phenyl(diphenylarsinoethyl)phosphino)ethane (diphars) (Scheme 1), was chosen for investigation so as to explore this possibility. Arsine ligated boronium salts are exceedingly rare, with the first example $\left[\mathrm{Cl}_{2} \mathrm{~B}\left\{\mathrm{C}_{6} \mathrm{H}_{4}\left(\mathrm{AsMe}_{2}\right)_{2}-1,2\right\}\right] \mathrm{BCl}_{4}$ having been only very recently reported by Reid ${ }^{18}$ who observed that it was considerably more labile than the corresponding diphosphine analogue. Thus it may be surmised that polar-covalent bonding between boron and the pnictogens becomes increasingly ineffective upon descending group 15 (stibine or bismuthine ligated boronium salts remain unknown). We therefore anticipated regioselective coordination of boron to the phosphine donors which is indeed what transpired. The reaction of $\mathrm{BrH}_{2} \mathrm{~B} \cdot \mathrm{SMe}_{2}$ with meso-diphars proceeded cleanly to the desired boronium salt 16 over a period of 18 hours (benzene, ambient temperature), in contrast to the formation of $\left[\mathrm{H}_{2} \mathrm{~B}\right.$ (dppe) $] \mathrm{Br}$, which was complete in under an hour (Scheme 3).

The diphars was found to retain its stereochemistry in the product, which meant that the compound was still achiral and in a meso form. The meso arrangement of the product was confirmed crystallographically, but disorder in the structural model illustrated that although the molecular ion comprised two symmetry generated halves, the central five-membered boronium ring was found to be oriented evenly over two

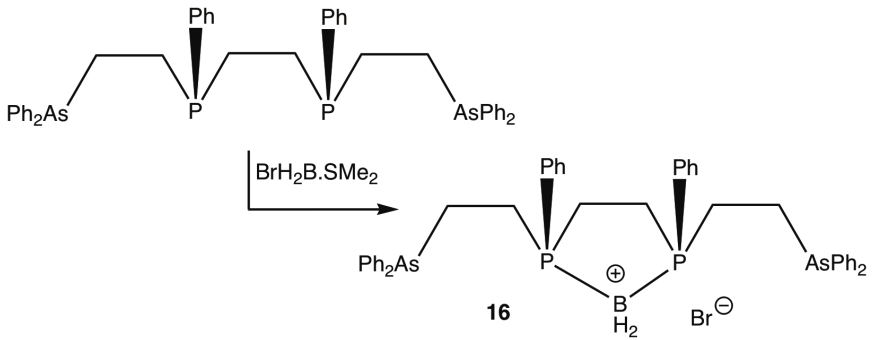

Scheme 3: Synthesis of meso- $\left[\mathrm{H}_{2} \mathrm{~B}\left(\kappa^{2}-P, P^{\prime}\right.\right.$-diphars $\left.)\right] \mathrm{Br}$ (16) through reaction of $\mathrm{BrH}_{2} \mathrm{~B} \cdot \mathrm{SMe}_{2}$ and meso-diphars.

possible orientations (

Figure 9). However, both orientations possessed a meso arrangement of the two phosphorus stereocentres. The possibility that $\mathbf{1 6}$ might provide a suitable geometry to allow the interaction of the boronium unit with a metal centre upon cordination of the pendant arsines was briefly explored but with little success. The reactions of $\mathbf{1 6}$ with either $\left[\mathrm{Mo}\left(\eta^{6}-\right.\right.$ $\left.\left.\mathrm{C}_{7} \mathrm{H}_{8}\right)(\mathrm{CO})_{3}\right]$ or $\left[\mathrm{RhCl}\left(\mathrm{PPh}_{3}\right)_{3}\right]$ afforded highly insoluble materials that were not amenable to spectroscopic interrogation other than the observation (+ve ion ESI-MS) of molecular ions corresponding to $\left[\mathrm{Mo}(\mathrm{CO})_{4}(16)\right]^{+}$and $\left[\mathrm{Rh}\left(\mathrm{PPh}_{3}\right)_{2}(16)\right]^{+}$, respectively.

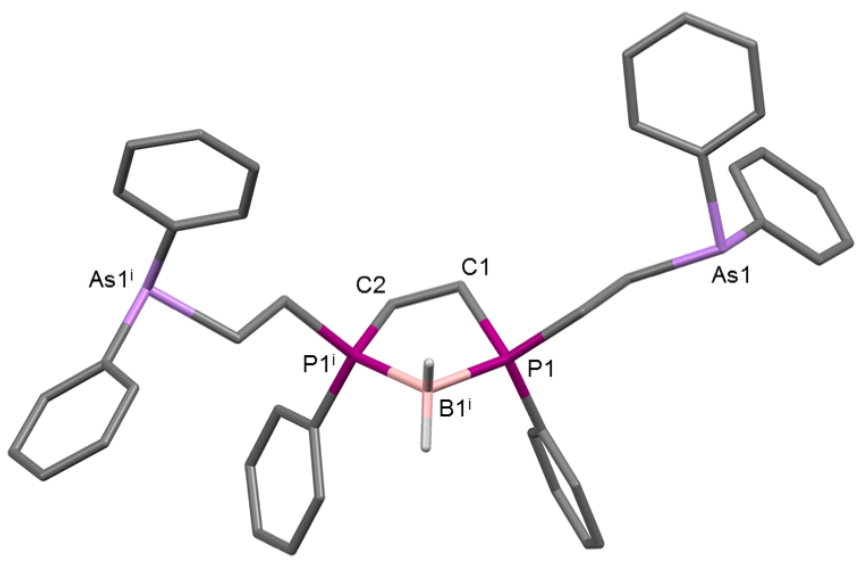

Figure 9: The molecular structure of the $\left[\mathrm{H}_{2} \mathrm{~B}\left(\kappa^{2}-P, P^{\prime} \text {-diphars }\right)\right]^{+}$cation in the salt 16 showing one of two positionally disordered orientations of the boracycle. (Bromide anions and aryl hydrogen atoms omitted for clarity, aryl groups simplified). Selected bond lengths ( $\AA$ ) and angles $\left({ }^{\circ}\right)$ : B1-P1 1.98(2); B1-P1 $1^{\mathrm{i}} 1.87(2)$; As1-C4 1.991(6); P1-B1-P1i 98(1); B1-P1-C1 97.9(8); B1-P1'-C2 108.4(7).

To further explore the possibility of using pendant donors to anchor boronium units proximal to metal more complicated species were considered. The reaction of $\mathrm{BrH}_{2} \mathrm{~B} \cdot \mathrm{SMe}_{2}$ with triphos $\left(\mathrm{MeC}\left(\mathrm{CH}_{2} \mathrm{PPh}_{2}\right)_{3}\right)$ afforded a boronium species within a six-membered heterocycle, to which was appended a pendant phosphine arm (Figure 10). The solid-state structure revealed a dimeric assembly for the packing of the $\left[\mathrm{H}_{2} \mathrm{~B} \text { (triphos) }\right]^{+}$cations via a rhomboid arrangement of two short and two long dihydrogen bonds between inversely polarised $\mathrm{C}-\mathrm{H}\left(\delta^{+}\right)$and $\mathrm{B}-\mathrm{H}\left(\delta^{-}\right)$bonds, respectively (Figure 11$) .{ }^{19}$ Dihydrogen bonding such as $\mathrm{C}-\mathrm{H} \cdots \mathrm{H}-\mathrm{B}$ is typically rather weak compared to more conventional hydrogen bond donors $\mathrm{N}-\mathrm{H}$ and $\mathrm{O}-\mathrm{H}$. 


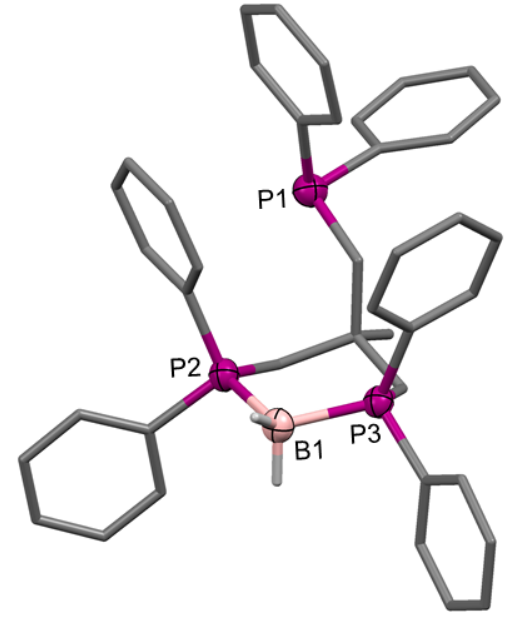

Figure 10: The molecular structure of $\left[\mathrm{H}_{2} \mathrm{~B}\right.$ (triphos) $] \mathrm{Br}$ (17; Bromide and aryl hydrogen atoms omitted for clarity, aryl groups simplified, $50 \%$ displacement ellipsoids). Selected bond lengths (Å) and angles $\left({ }^{\circ}\right)$ : B1-P2 1.921(4); B1-P3 1.932(4); P1-C1 1.852(4); P2-C2 1.825(3); P3-C3 1.816(3); P2-B1-P3 111.2(2); B1-P2-C2 109.5(2); B1-P3-C3 108.9(2); P2-C2-C4 118.2(2); P3-C3-C4 117.6(2); C2-C4-C3 111.2(3).

A caveat encountered in the synthesis of $\mathbf{1 7}$ was that the pendant phosphine arm was found on occasion to react with excess $\mathrm{BrH}_{2} \mathrm{~B} \cdot \mathrm{SMe}_{2}$ to form a bromoborane adduct $\left(\delta_{\mathrm{B}}-23.8, \delta_{\mathrm{p}}\right.$ -4.8 ) in conjunction to the boronium salt, which had almost identical behaviour towards various solvents as $\mathbf{1 7}$, making its separation problematic such that particular care must be taken with the stoichiometry of reagents during preparation.

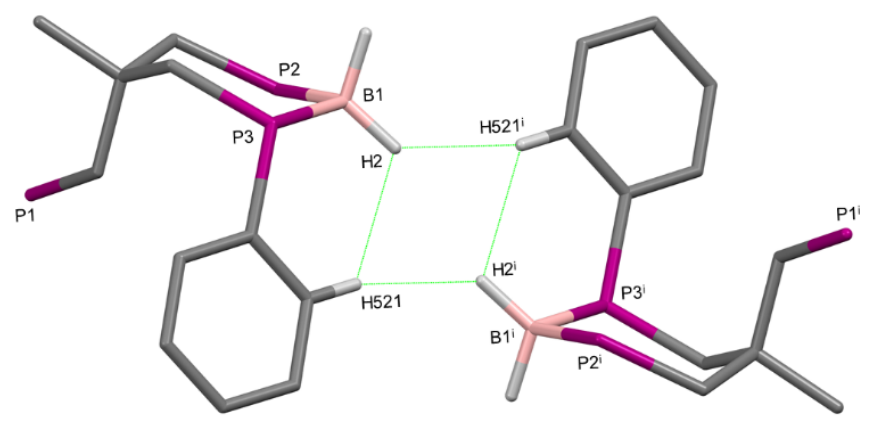

Figure 11: The centrosymmetric molecular packing of two $\left[\mathrm{H}_{2} \mathrm{~B} \text { (triphos) }\right]^{+}$cations of 17 illustrating the rhombic dihydrogen bonding. (Bromide anions, selected phenyl rings and alkyl hydrogen atoms omitted for clarity). Selected intra- and

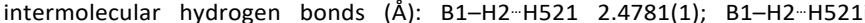
2.3783(1).

Discussion of Structural Features for Boronium Salts Complexes 1-3 were structurally characterised so as to study potential umpolung of the $\mathrm{B}-\mathrm{H}$ bond polarity via short contacts in their solid-state structures, with $\mathbf{3}$ being the only solid-state example of a boronium salt with two primary phosphine substituents. The molecular structures of some of the isolated boronium salts reveal short contacts between the cationic molecules and the counter-anions that are less than the van der Waals radii of the respective elements. The boronium salts of primary and secondary phosphines interact with the bromide via $\mathrm{P}-\mathrm{H} \cdots \mathrm{Br}$ hydrogen bonding, e.g., the $\mathrm{P}-\mathrm{H} \cdots \mathrm{Br}$ distances in $\left[\mathrm{H}_{2} \mathrm{~B}\left(\mathrm{PH}_{2} \mathrm{Cy}\right)_{2}\right] \mathrm{Br}$ range from $2.84-3.16 \AA$, with all four of the $\mathrm{P}-$ $\mathrm{H}$ hydrogen atoms in each molecule oriented so as to interact with the bromide counter-ion, along with two additional $\mathrm{P}-\mathrm{H}$ hydrogen atoms from neighbouring molecules (
Figure 12).

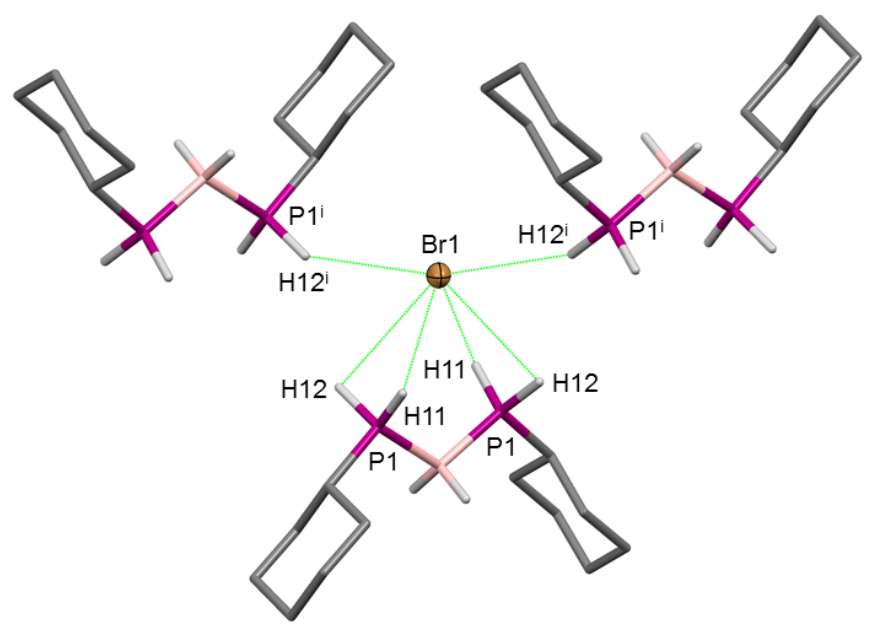

Figure 12: The molecular packing of three $\left[\mathrm{H}_{2} \mathrm{~B}\left(\mathrm{PH}_{2} \mathrm{Cy}\right)_{2}\right]^{+}$cations of 3 around a bromide anion showing the coordination sphere around the counterion. (Alkyl hydrogen atoms omitted for clarity, 50\% displacement ellipsoids). Selected intermolecular hydrogen bonds (Å): $\mathrm{P} 1-\mathrm{H} 11 \cdots \mathrm{Br} 1$ 3.0081(2); $\mathrm{P} 1-\mathrm{H} 12 \cdots \mathrm{Br} 1$ 3.1550(2); P1 ${ }^{i}-\mathrm{H} 12^{\mathrm{i} \ldots} \mathrm{Br} 12.8418(1)$

The solid-state structure of $\mathbf{1}$ is similar to that for $\mathbf{3}$, in that the constituents orient so that the bromide interacts with both $\mathrm{P}-\mathrm{H}$ hydrogen atoms ( $\mathrm{P}-\mathrm{H} \cdots \mathrm{Br}$ 2.9473(2), 3.8060(2) $\AA$ ), as well as a methine proton $(\mathrm{C}-\mathrm{H} \cdots \mathrm{Br} 2.7741(2) \AA)$ and one methylene proton ( $\mathrm{C}-\mathrm{H} \cdots \mathrm{Br} 3.0103(3) \AA$ ) from the same molecule (forming a four atom cradle as before). Whilst no single hydrogen bonding interaction is particularly short, the collective ensemble accounts for the well-ordered bromide position within the solid-state structure.

The crystal packing around the bromide counter-ion was less complex for $\mathbf{2}$ and the tertiary phosphine boronium salt $\mathbf{4}$ in comparison to those discussed above. For $\mathbf{2}$, the two P-H protons align so as to provide effectively equidistant hydrogen bonds of 2.8681(2) and 2.9243(2) $\AA$, but otherwise the anion was largely enveloped within a pocket faced by phenyl ring protons with distances of 3.10-3.77 ̊. For 4, the molecule was found to coordinate to the bromide via hydrogen bonding from the methyl and ortho-phenyl protons with distances of

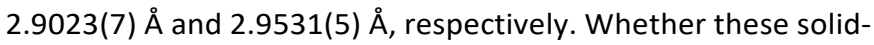
state interactions persist whilst in solution will be discussed later (vide infra), though depending on the solvent, a degree of ion-pairing might be expected.

These intermolecular interactions presumably contribute in part to the stability found for the boronium salts in the solid state. The intermolecular $\mathrm{P}-\mathrm{H} \cdots \mathrm{Br}$ interactions, however, do not appear to be limited to the solid-state, but may also be inferred to persist in solution. Both ${ }^{1} \mathrm{H}$ and ${ }^{31} \mathrm{P}$ NMR data for the boronium salts change markedly when the bromide anion is exchanged for a poorly coordinating counter-ion. The retention of $\mathrm{P}-\mathrm{H} \cdots \mathrm{Br}$ hydrogen bonding would be expected to result in a higher frequency shift of the ${ }^{1} \mathrm{H}$ NMR $\mathrm{P}-\mathrm{H}$ resonance, concomitant with a corresponding shift in the frequency of the ${ }^{31} \mathrm{P}$ NMR resonance, when compared to the shifts observed for a weakly coordinating counter-anion. The bromide counter-ion of 1 was exchanged for the essentially non-coordinating counter-ion $\left[\mathrm{SbF}_{6}\right]^{-}$by metathesis with $\mathrm{Ag}\left[\mathrm{SbF}_{6}\right]$ to give the new salt $\left[\mathrm{H}_{2} \mathrm{~B}\left(\mathrm{PHCy}_{2}\right)_{2}\right]\left[\mathrm{SbF}_{6}\right]$ (18). Notably, the ${ }^{1} \mathrm{H}$ and ${ }^{31} \mathrm{P} N M R$ 
signals for the unchanged $\left[\mathrm{H}_{2} \mathrm{~B}\left(\mathrm{PHCy}_{2}\right)_{2}\right]^{+}$cation were significantly altered by the simple exchange of the anion present. The ${ }^{1} \mathrm{H}$ NMR $\mathrm{P}-\mathrm{H}$ peak for 1 was observed at $6.04 \mathrm{ppm}$, whilst for $\left[\mathrm{H}_{2} \mathrm{~B}\left(\mathrm{PHCy}_{2}\right)_{2}\right]\left[\mathrm{SbF}_{6}\right]$ it was observed at $4.89 \mathrm{ppm}$ suggesting a persistent interaction with the bromide counterion. Similarly, the ${ }^{31} \mathrm{P}$ NMR peak at $-1.2 \mathrm{ppm}$ for 1 and $-3.3 \mathrm{ppm}$ for 18 also point toward a degree of ion-pairing with the bromide counter-ion in this solvent $\left(\mathrm{CDCl}_{3}\right)$. The solid-state structure of $\mathbf{1 8}$ was found to possess the same coordination of the anion by the two $\mathrm{PH}$ groups as observed for $\mathbf{1}$, which indicated that the $\left[\mathrm{H}_{2} \mathrm{~B}\left(\mathrm{PHCy}_{2}\right)_{2}\right]^{+}$cation was still able to coordinate to the larger $\left[\mathrm{SbF}_{6}\right]^{-}$anion in the solid state, however, any such interaction in solution, were it to persist, must be dynamic since there was no indication of enduring coupling between the ${ }^{31} \mathrm{P}-1{ }^{1} \mathrm{H}$ and ${ }^{19} \mathrm{~F}$ nuclei.

The salt $\mathbf{1 8}$ was found to be less stable than its bromide counter-ion analogue $\mathbf{1}$ and decomposed in the solid-state over the comparatively short period of a week (cf. 1 showed no appreciable decomposition in anaerobic solution after several weeks). The ${ }^{31} \mathrm{P}$ and ${ }^{11} \mathrm{~B}$ NMR spectra of the resulting decomposition mixture did not reveal any resonances that might suggest $\mathrm{P}-\mathrm{F}$ or $\mathrm{B}-\mathrm{F}$ bond formation, i.e., fluoride abstraction does not appear to have ensued. Similarly, $\left[\mathrm{H}_{2} \mathrm{~B}\left(\mathrm{PMe}_{2} \mathrm{Ph}\right)_{2}\right]\left[\mathrm{AsF}_{6}\right](\mathbf{1 9})$ was prepared by metathesis of 4 with $\mathrm{K}\left[\mathrm{AsF}_{6}\right]$ which was used in preference to $\mathrm{Ag}\left[\mathrm{SbF}_{6}\right]$ due to the observed decomposition of some boronium salts when treated with $\mathrm{Ag}\left[\mathrm{SbF}_{6}\right]$. It was found that the reaction did not always proceed as expected with $\mathrm{Ag}\left[\mathrm{SbF}_{6}\right]$, and that sometimes what was believed to be a silver phosphine species $\left(\delta_{p} 42.2\right)$ was the major product recovered. This decomposition of the boronium cation was not observed when $\left.\mathrm{K}^{2} \mathrm{AsF}_{6}\right]$ was used instead, and it therefore became the preferred reagent for anion metathesis. Although silver salts are powerful halide sequestering agents, the attendant caveat is that they are also prone to single electron redox processes (to form silver metal) such that their use in the presence of $\mathrm{B}\left(\delta^{+}\right)-\mathrm{H}\left(\delta^{-}\right)$bonds, i.e., classical reductants, is likely to be problematic on occasion.

The tertiary phosphine boronium salts 4 and 19 were found to present the same trend of anion coordination as previously discussed for salts 1 and 18. However, the hydrogen bonding observed in the solid state for $\mathbf{4}$ was understandably found to be less pronounced than for the secondary phosphine analogue, directly due to the lack of $\mathrm{P}-\mathrm{H}$ bonds. The ${ }^{1} \mathrm{H}$ and ${ }^{31} \mathrm{P}$ NMR peaks for 4 were $\delta_{H} 2.00$ (methyl groups) and $\delta_{P}-3.5$, whilst for 19 they were found to be $\delta_{H} 1.68$ and $\delta_{P}-3.6$. Therefore, the difference in the NMR resonances caused by changing the counter-ion was less pronounced in comparison to the $\left[\mathrm{H}_{2} \mathrm{~B}\left(\mathrm{PHCy}_{2}\right)_{2}\right]^{+}$salts, but still followed the same pattern of the resonances shifting to lower frequency as $\mathrm{Br}^{-}$was exchanged for $\left[\mathrm{AsF}_{6}\right]^{-}$.

The boronium salt $\left[\mathrm{H}_{2} \mathrm{~B}\right.$ (triphos)][AsF $\left.\mathrm{A}_{6}\right]$ (20) was also synthesised for comparison and structurally characterised. The solid-state structure of $\mathbf{2 0}$ was similarly (cf. 19) found to coordinate to the $\left[\mathrm{AsF}_{6}\right]^{-}$anion via the methylene groups of the $\left[\mathrm{H}_{2} \mathrm{~B} \text { (triphos) }\right]^{+}$cation, though in this case through all three of the methylene groups, including the methylene of the pendant phosphine arm. Short hydrogen bond interactions of 2.559(6) and 2.588(4) ^ were observed for the boracycle methylene protons and the pendant phosphine arm methylene protons, respectively. Similar to the acyclic boronium cations such as $\left[\mathrm{H}_{2} \mathrm{~B}\left(\mathrm{PHCy}_{2}\right)_{2}\right]^{+}$, the effect of anion substitution of the bromide by $\left[\mathrm{AsF}_{6}\right]^{-}$was observed again in solution. This was found with a shift to lower frequency for the multiplets attributed to the methylene protons in the ${ }^{1} \mathrm{H}$ NMR spectrum for $20\left(\delta_{\mathrm{H}} 2.67\right.$, 2.72-2.84) in comparison to $17\left(\delta_{H} 3.17-3.43,3.68-3.86\right)$. Interestingly, the solid-state conformation for $\mathbf{2 0}$ had the pendant phosphine arm in the equatorial position, whilst for $\mathbf{1 7}$ this was observed in an axial position which is less common for sterically demanding substituents on a cyclohexane scaffold (Figure 13).

\section{Conclusions}

In conclusion, an extensive library of boronium salts has been compiled and structurally characterised. The ease of formation and high purity of boronium salts synthesised from two equivalents of a secondary or primary phosphine and $\mathrm{BrH}_{2} \mathrm{~B} \cdot \mathrm{SMe}_{2}$ made them ideal starting materials. Unfortunately, these boronium salts were found to possess low reactivity and were therefore deemed unsuitable for further modification. This led to a second generation of boronium salts that involved utilising the differing $\sigma$-basicity between phosphine and arsine groups to selectively coordinate to the boron substituent via the phosphine, leaving the arsine groups free for further synthesis; Or, alternatively the use of the triphosphine species 'triphos' in reaction with $\mathrm{BrH}_{2} \mathrm{~B} \cdot \mathrm{SMe}_{2}$ which was found to yield a boronium salt that also possessed a pendant phosphine arm that could act as a tether to metal centres.

The increased functionality introduced by synthesising boronium salts bearing a bromine atom on the boron offered a potential site at which subsequent manipulations could be envisaged. However, the synthesis of such $\mathrm{BHBr}$ boronium species from $\mathrm{Br}_{2} \mathrm{HB} \cdot \mathrm{SMe}_{2}$ presented new difficulties as compared to the straightforward synthesis of the $\mathrm{BH}_{2}$ boronium species. As a result, only a small number of $\mathrm{BHBr}$ boronium salts could be produced, and only one of them (15) could be adequately isolated and handled. Research into further manipulation of the potentially useful $\mathrm{B}-\mathrm{Br}$ functional group is ongoing.

\section{EXPERIMENTAL SECTION}

General Considerations. All manipulations were carried out under a dry and oxygen-free nitrogen atmosphere using standard Schlenk, vacuum-line, and inert-atmosphere drybox (argon) techniques, with dried and degassed solvents which were distilled from either calcium hydride $\left(\mathrm{CH}_{2} \mathrm{Cl}_{2}\right)$, magnesium metal (alcohols) or sodium and benzophenone (ethers and paraffins). NMR spectra were obtained at $25^{\circ} \mathrm{C}$ on an Inova 300 spectrometer $\left({ }^{1} \mathrm{H}\right.$ at $299.94 \mathrm{MHz},{ }^{13} \mathrm{C}$ at $75.42 \mathrm{MHz},{ }^{11} \mathrm{~B}$ at 96.23 $\mathrm{MHz},{ }^{19} \mathrm{~F}$ at $282.23 \mathrm{MHz},{ }^{31} \mathrm{P}$ at $121.42 \mathrm{MHz}$ ), a Mercury 400 


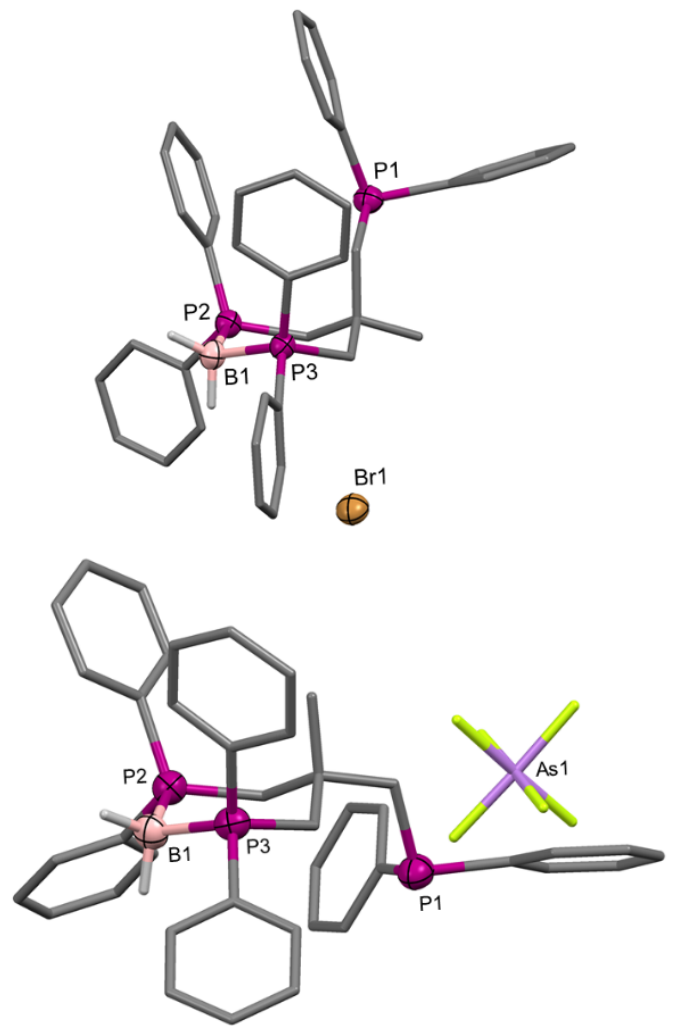

Figure 13: The molecular structure of 17 (above) and 20 (below). (Solvate molecules and aryl hydrogen atoms omitted for clarity, aryl groups simplified, 50\% displacement ellipsoids). Selected bond lengths $(A \circ)$ and angles $\left({ }^{\circ}\right)$ for 17: B1-P2 1.921(4); B1-P3 1.932(4); P1-C1 1.852(4); P2-C2 1.825(3); P3-C3 1.816(3); P2-B1-P3 111.2(2); B1-P2-C2 109.5(2); B1-P3-C3 108.9(2); P2-C2-C4 118.2(2); P3-C3-C4 117.6(2); C2-C4-C3 111.2(3). Selected bond lengths $(\AA)$, angles $\left({ }^{\circ}\right)$ and intermolecular distances (Å) for 20: B1-P2 1.918(7); B1-P3 1.927(7); P1-C1 1.866(6); P2-C2 1.818(6); P3-C3 1.814(6); P2-B1-P3 110.7(3); B1-P2-C2 109.7(3); B1-P3-C3 110.6(3); P2-C2-C4 118.5(4); P3-C3-C4 117.0(4); C2-C4-C3 111.1(4); C1-H11...F6 2.588(4); C3-H32...F5 2.559(6).

spectrometer $\left({ }^{1} \mathrm{H}\right.$ at $399.87 \mathrm{MHz},{ }^{13} \mathrm{C}$ at $100.56 \mathrm{MHz},{ }^{31} \mathrm{P}$ at 161.87 $\mathrm{MHz})$, a Bruker 400 spectrometer $\left({ }^{1} \mathrm{H}\right.$ at $400.14 \mathrm{MHz}$ and ${ }^{13} \mathrm{C}$ at $100.63 \mathrm{MHz},{ }^{11} \mathrm{~B}$ at $128.38 \mathrm{MHz},{ }^{31} \mathrm{P}$ at $161.97 \mathrm{MHz}$ ) and an Inova 500 spectrometer $\left({ }^{1} \mathrm{H}\right.$ at $500.04 \mathrm{MHz},{ }^{13} \mathrm{C}$ at $125.75 \mathrm{MHz}$,). Chemical shifts are quoted in ppm relative to external $\mathrm{SiMe}_{4}\left({ }^{1} \mathrm{H},{ }^{13} \mathrm{C}\right), \mathrm{H}_{3} \mathrm{PO}_{4}\left({ }^{31} \mathrm{P}\right)$, $\mathrm{BF}_{3} . \mathrm{Et}_{2} \mathrm{O}\left({ }^{11} \mathrm{~B}\right)$ or $\mathrm{C}_{6} \mathrm{~F}_{6}\left({ }^{19} \mathrm{~F}\right)$ references with $\mathrm{n}$-bond couplings between nuclei $A$ and $B, n J_{A B}$, being quoted in $\mathrm{Hz}$. It should be noted that due to the $3 / 2$ spin of NMR active quadrupolar ${ }^{11} \mathrm{~B}$, the resulting spectra are naturally broad and $\mathrm{B}-\mathrm{H}$ coupling is often not resolved. ${ }^{11} \mathrm{~B}-{ }^{1} \mathrm{H}$ coupled spectra are only reported if couplings were reliably resolved. The $\mathrm{B}-\mathrm{H}$ signals are also rarely observed in ${ }^{1} \mathrm{H}$ NMR spectra, owing to the ${ }^{11} \mathrm{~B}$ coupling that causes the peaks to be especially broad, and as such are not reported here. Spectra of NMR active ${ }^{31} \mathrm{P}$ nuclei bonded to ${ }^{11} \mathrm{~B}$ also experience quadrupolar broadening of their signals, which can often cause imprecise coupling values; in these cases, an average value is reported and stated as such. Computational calculations were performed using Spartan 14 at the MO6-LACVP level of theory. Elemental microanalysis was performed by the microanalytical service of the Australian National University and unless otherwise noted, recrystallized samples were dried for a prolonged period in vacuo. Electrospray (ESI) mass spectrometry was performed by the Research School of Chemistry mass spectrometry service, and unless otherwise stated, the accurate mass data are reported for the most abundant isotopomer. For salts, $[\mathrm{M}]^{+}$and $[\mathrm{M}]^{-}$refer to the cationic and anionic component of the salt respectively. Typically, a sample was dissolved in dichloromethane and then diluted with methanol or acetonitrile immediately before being analysed. X-ray crystallographic data were collected with a Nonius Kappa CCD diffractometer, an Agilent Xcalibur CCD diffractometer or an Agilent SuperNova CCD diffractometer. Data were extracted using the Denzo (Nonius) or CrysAlis (Agilent) packages, with structure solutions being solved by direct methods (SIR92, Superflip) using the CRYSTALS program package. All reagents were used as received from commercial sources. During our studies, the compounds $\mathbf{1}, \mathbf{2}$ and $\mathbf{3}^{\mathbf{7 j}}$ were reported without structural characterisation which is now detailed here. The salt $7^{8}$ has also been described previously, however only limited spectroscopic data were provided (IR, $1 \mathrm{H}$ NMR).

Synthesis of $\left[\mathrm{H}_{2} \mathrm{~B}(\mathrm{PHCy})_{2}\right] \mathrm{Br}(1)$. A solution of $\mathrm{BrH}_{2} \mathrm{~B} \cdot \mathrm{SMe}_{2}$ $(1.0 \mathrm{M}, 1.00 \mathrm{~mL}, 1.0 \mathrm{mmol})$ in dichloromethane was added dropwise to a stirred solution of dicyclohexylphosphine ( $\rho=0.98$ $\left.\mathrm{gcm}^{-3}, 0.40 \mathrm{~mL}, 2.0 \mathrm{mmol}\right)$ in pentane $(10 \mathrm{~mL})$ at $0^{\circ} \mathrm{C}$. Approximately 5 minutes after addition a precipitate formed. The mixture was stirred for $1 \mathrm{~h}$ at room temperature, and then all volatiles were removed under high vacuum to leave a pale orange solid. The solid was further dried under high vacuum for $48 \mathrm{~h}$. The solid was recrystallised from a mixture of $\mathrm{DCM} /$ pentane to produce colourless $\mathrm{X}$-ray diffraction quality crystals. Yield $0.37 \mathrm{~g}(0.76 \mathrm{mmol}, 76 \%)$. M.p. $199-201^{\circ} \mathrm{C}$. Anal. Found: $\mathrm{C}, 58.63 ; \mathrm{H}, 10.05 ; \mathrm{N}, 0.00 \%$. Calcd. for $\mathrm{C}_{24} \mathrm{H}_{48} \mathrm{BBrP}_{2}$ : C, 58.91; $\mathrm{H}, 9.89 ; \mathrm{N}, 0.00 \%$. NMR $\left(\mathrm{CD}_{2} \mathrm{Cl}_{2}, 25^{\circ} \mathrm{C}\right):{ }^{1} \mathrm{H}: \delta_{\mathrm{H}}=1.25-2.27$ $\left(\mathrm{m}, 44 \mathrm{H}, \mathrm{C}_{6} \mathrm{H}_{11}\right), 5.78\left(\mathrm{~d},{ }^{1} \mathrm{P}_{\mathrm{PH}} 407.3 \mathrm{~Hz}, 2 \mathrm{H}, \mathrm{PH}\right) ;{ }^{11} \mathrm{~B}\left\{{ }^{1} \mathrm{H}\right\}: \delta_{\mathrm{B}}=-$ $45.2(\mathrm{br}) ;{ }^{11} \mathrm{~B}: \delta_{\mathrm{B}}=-45.2\left(\mathrm{~d} . \mathrm{br},{ }^{1} J_{\mathrm{BH}} 92 \mathrm{~Hz}\right) ;{ }^{13} \mathrm{C}\left\{{ }^{1} \mathrm{H}\right\}: \delta_{\mathrm{C}}=25.49$ $\left[\mathrm{C}^{2,6}\left(\mathrm{C}_{6} \mathrm{H}_{11}\right)\right], 26.38\left[\mathrm{~m}, \mathrm{C}^{4}\left(\mathrm{C}_{6} \mathrm{H}_{11}\right)\right], 28.26\left[\mathrm{~d},{ }^{1}\right]_{\mathrm{PC}} 55.7 \mathrm{~Hz}$, $\left.\mathrm{C}^{1}\left(\mathrm{C}_{6} \mathrm{H}_{11}\right)\right], 29.20\left[\mathrm{~d},{ }^{1} J_{\mathrm{PC}} 40.5 \mathrm{~Hz}, \mathrm{C}^{3,5}\left(\mathrm{C}_{6} \mathrm{H}_{11}\right)\right] ;{ }^{1} \mathrm{P}\left\{{ }^{1} \mathrm{H}\right\}: \delta_{\mathrm{P}}=-0.4$ (d.br, ${ }^{1} J_{\mathrm{PB}} 93 \mathrm{~Hz}$ ); ${ }^{31 \mathrm{P}:} \delta_{\mathrm{P}}=-0.5$ (dd.br, ${ }^{1} \mathrm{~J}_{\mathrm{PH}} /{ }^{1} \mathrm{JPB}_{\mathrm{PB}} 399 / 93 \mathrm{~Hz}$ ). NMR $\left(\mathrm{CDCl}_{3}, 25^{\circ} \mathrm{C}\right):{ }^{1} \mathrm{H}: \delta_{\mathrm{H}}=1.25-2.27\left(\mathrm{~m}, 44 \mathrm{H}, \mathrm{C}_{6} \mathrm{H}_{11}\right), 6.04\left(\mathrm{~d},{ }^{1} J_{\mathrm{PH}}\right.$ $408.1 \mathrm{~Hz}, 2 \mathrm{H}, \mathrm{PH}$ ); ${ }^{11} \mathrm{P}\left\{{ }^{1} \mathrm{H}\right\}: \delta_{\mathrm{P}}=-1.2$ (d.br, ${ }^{1} j_{\mathrm{PB}} 79.4 \mathrm{~Hz}$ ). Acc. Mass: Found: $m / z=409.3323$. Calcd. for $\mathrm{C}_{24} \mathrm{H}_{48}{ }^{11} \mathrm{BP}_{2} 409.3324$ $[\mathrm{M}]^{+}$. Crystal data: $\mathrm{C}_{24} \mathrm{H}_{48} \mathrm{BBrP}_{2}, M_{\mathrm{r}}=489.31, T=200(2) \mathrm{K}$, triclinic, space group $P-1$ (No.2), $a=11.1026(3), b=12.0068(3)$, $c=12.5924(3) \AA, \alpha=117.0693(11), \beta=109.9315(14), \gamma=$ 96.4193(13) $)^{\circ}, V=1331.87(7) \AA^{3}, Z=2, D_{\text {calcd. }}=1.220 \mathrm{Mg} \mathrm{m}^{-3}$, $\mu($ Mo K $\alpha) 1.67 \mathrm{~mm}^{-1}$, colourless block, $0.23 \times 0.24 \times 0.36 \mathrm{~mm}$, 18303 measured reflections with $2 \theta_{\max }=56.6^{\circ}, 6125$ independent reflections, 6108 absorption-corrected data used in $F^{2}$ refinement, 254 parameters, no restraints, $R_{1}=0.033, w R_{2}$ $=0.076$ for 5022 reflections with $I>2 \sigma(I)$.

Synthesis of $\left[\mathrm{H}_{2} \mathrm{~B}\left(\mathrm{PHPh}_{2}\right)_{2}\right] \mathrm{Br}(2)$. A solution of $\mathrm{BrH}_{2} \mathrm{~B} . \mathrm{SMe}_{2}$ $(1.0 \mathrm{M}, 0.5 \mathrm{~mL}, 0.5 \mathrm{mmol}$ ) in dichloromethane was added dropwise to a stirred solution of diphenylphosphine $\left(\rho=1.07 \mathrm{gcm}^{-3}\right.$, $0.17 \mathrm{~mL}, 1.0 \mathrm{mmol}$ ) in pentane $(4 \mathrm{~mL})$. Upon addition a precipitate was formed instantly, but after 1 minute an orange oil had aggregated at the bottom of the flask and the bulk solution was colourless. The mixture was stirred for $1 \mathrm{~h}$, and then all volatiles were removed under high vacuum to leave a pale orange solid. The solid was further dried under high vacuum for $24 \mathrm{~h}$. The solid was dissolved in DCM and layered with pentane to give white powder, which was isolated by cannula filtration. The solid was recrystallised from a mixture of DCM/pentane to produce colourless X-ray diffraction quality crystals. Yield $0.20 \mathrm{~g}(0.43 \mathrm{mmol}, 87 \%)$. Partially melted at around $\mathrm{ca}$. $98^{\circ} \mathrm{C}$, then remained unchanged up to $250^{\circ} \mathrm{C}$. Consistent elemental analytical data not obtained: Anal. Found: C, 61.16; $\mathrm{H}, 4.95 ; \mathrm{N}, 0.00 \%$. Calcd. for $\mathrm{C}_{24} \mathrm{H}_{24} \mathrm{BBrP}_{2}$ : C, 61.98; $\mathrm{H}$, 5.20; N, 0.00\%. NMR $\left(\mathrm{CD}_{2} \mathrm{Cl}_{2}, 25^{\circ} \mathrm{C}\right):{ }^{1} \mathrm{H}: \delta_{\mathrm{H}}=7.31-7.39(\mathrm{~m}, 8 \mathrm{H}$, $\left.\mathrm{C}_{6} \mathrm{H}_{5}\right)$, 7.46-7.51 (m, 4H, $\left.\mathrm{C}_{6} \mathrm{H}_{5}\right), 7.64-7.71\left(\mathrm{~m}, 8 \mathrm{H}, \mathrm{C}_{6} \mathrm{H}_{5}\right), 8.95(\mathrm{~d}$, 
$\left.{ }^{1} J_{\mathrm{PH}} 456.4 \mathrm{~Hz}, 2 \mathrm{H}, \mathrm{PH}\right) ;{ }^{11} \mathrm{~B}\left\{{ }^{1} \mathrm{H}\right\}: \delta_{\mathrm{B}}=-37.6(\mathrm{br}) ;{ }^{11} \mathrm{~B}: \delta_{\mathrm{B}}=-38.1$ (d.br, ${ }^{2} J_{\mathrm{BH}} 70 \mathrm{~Hz}$ ); ${ }^{13} \mathrm{C}\left\{{ }^{1} \mathrm{H}\right\}: \delta_{\mathrm{C}}=122.22\left[\mathrm{~d},{ }^{1} J_{\mathrm{PC}} 60.8 \mathrm{~Hz}, \mathrm{C}^{1}\left(\mathrm{C}_{6} \mathrm{H}_{5}\right)\right]$, $129.76\left[\mathrm{~m}, \mathrm{C}^{2,6}\left(\mathrm{C}_{6} \mathrm{H}_{5}\right)\right], 132.93\left[\mathrm{C}^{4}\left(\mathrm{C}_{6} \mathrm{H}_{5}\right)\right], 133.52\left[\mathrm{~m}, \mathrm{C}^{3,5}\left(\mathrm{C}_{6} \mathrm{H}_{5}\right)\right]$; ${ }^{31} \mathrm{P}\left\{{ }^{1} \mathrm{H}\right\}: \delta_{\mathrm{P}}=-16.2\left(\mathrm{~d} . \mathrm{br},{ }^{1} J_{\mathrm{PB}} 86 \mathrm{~Hz}\right) .{ }^{31} \mathrm{P}: \delta_{\mathrm{P}}=-16.2\left(\mathrm{dm} \cdot \mathrm{br},{ }^{1}{ }_{\mathrm{PH}}\right.$ $376 \mathrm{~Hz}$ ). Acc. Mass: Found: $m / z=385.1446$ Calcd. for $\mathrm{C}_{24} \mathrm{H}_{24}{ }^{11} \mathrm{BP}_{2} 385.1446[\mathrm{M}]^{+}$. Crystal data: $\mathrm{C}_{24} \mathrm{H}_{24} \mathrm{BBrP}_{2}, M_{\mathrm{r}}=$ 465.12, $T=200(2) \mathrm{K}$, monoclinic, space group $P 2_{1} / n, a=$ 8.3066(1), $b=18.0004(3), c=15.1242(2) \AA, \beta=97.2060(9)^{\circ}, V=$ 2243.54(6) $\AA^{3}, Z=4, D_{\text {calcd. }}=1.377 \mathrm{Mg} \mathrm{m}^{-3}, \mu($ Mo K $\alpha) 1.98 \mathrm{~mm}^{-}$ 1 , colourless block, $0.14 \times 0.20 \times 0.29 \mathrm{~mm}, 25261$ measured reflections with $2 \theta_{\max }=55.0^{\circ}, 5139$ independent reflections, 5124 absorption-corrected data used in $F^{2}$ refinement, 254 parameters, no restraints, $R_{1}=0.030, w R_{2}=0.077$ for 4263 reflections with $I>2 \sigma(I)$.

Synthesis of $\left[\mathrm{H}_{2} \mathrm{~B}\left(\mathrm{PH}_{2} \mathrm{Cy}\right)_{2}\right] \mathrm{Br}$ (3). A solution of $\mathrm{BrH}_{2} \mathrm{~B} . \mathrm{SMe}_{2}$ $(1.0 \mathrm{M}, 0.50 \mathrm{~mL}, 0.5 \mathrm{mmol})$ in dichloromethane was added dropwise to a stirred solution of cyclohexylphosphine ( $\rho=0.88$ $\left.\mathrm{gcm}^{-3}, 0.13 \mathrm{~mL}, 1.0 \mathrm{mmol}\right)$ in pentane $(2 \mathrm{~mL})$. The mixture was stirred for $1 \mathrm{~h}$, after which time an orange oil had aggregated at the bottom of the flask and the bulk solution was colourless. All volatiles were removed under high vacuum to leave a pale orange solid. The solid was recrystallised from a mixture of DCM/pentane to give a white powder. The solid was then recrystallized by layering a concentrated DCM solution of the solid with pentane overnight to produce colourless X-ray diffraction quality crystals. Yield $0.07 \mathrm{~g}(0.20 \mathrm{mmol}, 41 \%)$. Evolved a gas at $76^{\circ} \mathrm{C}$ to leave a clear residue up to $250^{\circ} \mathrm{C}$. Anal. Found: $\mathrm{C}, 44.15 ; \mathrm{H}, 8.35 ; \mathrm{N}, 0.00 \%$. Calcd. for $\mathrm{C}_{12} \mathrm{H}_{28} \mathrm{BBrP}_{2}$ : $\mathrm{C}$, 44.35; $\mathrm{H}, 8.68 ; \mathrm{N}, 0.00 \%$. NMR $\left(\mathrm{CD}_{2} \mathrm{Cl}_{2}, 25^{\circ} \mathrm{C}\right):{ }^{1} \mathrm{H}: \delta_{\mathrm{H}}=1.34-2.22$ $\left(\mathrm{m}, 22 \mathrm{H}, \mathrm{C}_{6} \mathrm{H}_{11}\right), 5.60\left(\mathrm{~d},{ }^{1}{ }_{\mathrm{PH}} 425.9 \mathrm{~Hz}, 4 \mathrm{H}, \mathrm{PH}\right) ;{ }^{11} \mathrm{~B}\left\{{ }^{1} \mathrm{H}\right\}: \delta_{\mathrm{B}}=-44.5$ (t.br, ${ }^{1} J_{\mathrm{BP}} 81 \mathrm{~Hz}$ ); ${ }^{11} \mathrm{~B}: \delta_{\mathrm{B}}=-44.5\left(\mathrm{tt} . b r,{ }^{1} J_{\mathrm{BH}} \approx{ }^{1} J_{\mathrm{BP}} 90 \mathrm{~Hz}\right) ;{ }^{13} \mathrm{C}\left\{{ }^{1} \mathrm{H}\right\}$ : $\delta_{\mathrm{C}}=25.69\left[\mathrm{C}^{3,5}\left(\mathrm{C}_{6} \mathrm{H}_{11}\right)\right], 26.51\left[\mathrm{t}, \mathrm{J}_{\mathrm{PC}} 6.3 \mathrm{~Hz}, \mathrm{C}^{2,6}\left(\mathrm{C}_{6} \mathrm{H}_{11}\right)\right], 28.93[\mathrm{~d}$, $\left.{ }^{1} J_{\mathrm{PC}} 45.5 \mathrm{~Hz}, \mathrm{C}^{1}\left(\mathrm{C}_{6} \mathrm{H}_{11}\right)\right], 30.12\left[\mathrm{C}^{4}\left(\mathrm{C}_{6} \mathrm{H}_{11}\right)\right] ;{ }^{31} \mathrm{P}\left\{{ }^{1} \mathrm{H}\right\}: \delta_{\mathrm{P}}=-38.6$ (q.br, ${ }^{1} J_{\mathrm{PB}} 94 \mathrm{~Hz}$ ); ${ }^{31 \mathrm{P}:} \delta_{\mathrm{P}}=-38.7$ [td.br, ${ }^{1} J_{\mathrm{PH}} 415 \mathrm{~Hz}$ (Average), ${ }^{1} J_{\mathrm{PB}}$ $82 \mathrm{~Hz}$. Acc. Mass: Found: $m / z=245.1759$ Calcd for $\mathrm{C}_{12} \mathrm{H}_{28}{ }^{11} \mathrm{BP}_{2}$ $245.1759[\mathrm{M}]^{+}$. Crystal data: $\mathrm{C}_{12} \mathrm{H}_{28} \mathrm{BBrP}_{2}, \mathrm{Mr}_{\mathrm{r}}=325.02, T=$ 200(2) K, orthorhombic, space group Pbcn, $a=13.5244(3), b=$ 12.0969(3), $c=9.8466(2) \AA, V=1610.94(6) \AA^{3}, Z=4, D_{\text {calcd }}=$ $1.340 \mathrm{Mg} \mathrm{m}^{-3}, \mu($ Mo K $\alpha) 2.73 \mathrm{~mm}^{-1}$, colourless block, $0.14 \times 0.26$ $\times 0.27 \mathrm{~mm}, 16490$ measured reflections with $2 \theta_{\max }=60.1^{\circ}$, 2352 independent reflections, 2348 absorption-corrected data used in $F^{2}$ refinement, 75 parameters, no restraints, $R_{1}=0.026$, $w R_{2}=0.065$ for 1852 reflections with $I>2 \sigma(I)$.

Synthesis of $\left[\mathrm{H}_{2} \mathrm{~B}\left(\mathrm{PMe}{ }_{2} \mathrm{Ph}\right)_{2}\right] \mathrm{Br}$ (4). A solution of $\mathrm{BrH}_{2} \mathrm{~B} . \mathrm{SMe}_{2}(1.0 \mathrm{M}, 1.00 \mathrm{~mL}, 1.0 \mathrm{mmol})$ in dichloromethane was added drop-wise to a stirred solution of dimethylphenylphosphine ( $\left.\rho=0.97 \mathrm{gcm}^{-3}, 0.28 \mathrm{~mL}, 2.0 \mathrm{mmol}\right)$ in benzene $(10 \mathrm{~mL})$. Upon addition the solution changed to a bright purple colour, which faded first to brown and then to orange over $45 \mathrm{~min}$. The mixture was stirred for $2 \mathrm{~h}$, and then all volatiles were removed under high vacuum to leave an orange oil. The oil was dried under high vacuum for $24 \mathrm{~h}$ to produce a white solid. The solid was recrystallised from a mixture of $\mathrm{DCM} /$ pentane to give $\mathrm{X}$-ray diffraction quality colourless needles. Yield $0.32 \mathrm{~g}(0.85 \mathrm{mmol}, 85 \%)$. Compound melted and re-solidified at around $108^{\circ} \mathrm{C}$, then remained unchanged up to $250^{\circ} \mathrm{C}$. Anal. Found: C, 50.20; H, 6.67; N,
0.00\%. Calcd. for $\mathrm{C}_{16} \mathrm{H}_{24} \mathrm{BBrP}_{2} .0 .25\left(\mathrm{CH}_{2} \mathrm{Cl}_{2}\right): \mathrm{C}, 50.01 ; \mathrm{H}, 6.33 ; \mathrm{N}$, $0.00 \%$. The solvated DCM was observed in the (integrated) ${ }^{1} \mathrm{H}$ and ${ }^{13} \mathrm{C}$ NMR spectra. NMR $\left(\mathrm{CD}_{2} \mathrm{Cl}_{2}, 25^{\circ} \mathrm{C}\right):{ }^{1} \mathrm{H}: \delta_{\mathrm{H}}=1.84\left(\mathrm{~d},{ }^{2} \mathrm{~J}_{\mathrm{PH}}\right.$ $\left.9.9 \mathrm{~Hz}, 12 \mathrm{H}, \mathrm{CH}_{3}\right), 7.50-7.60\left(\mathrm{~m}, 10 \mathrm{H}, \mathrm{C}_{6} \mathrm{H}_{5}\right) ;{ }^{11} \mathrm{~B}\left\{{ }^{1} \mathrm{H}\right\}: \delta_{\mathrm{B}}=-33.2$ (t.br, $\left.{ }^{1} J_{\mathrm{BP}} 90 \mathrm{~Hz}\right) ;{ }^{11} \mathrm{~B}: \delta_{\mathrm{B}}=-33.2\left(\mathrm{dt} . b r,{ }^{1} J_{\mathrm{BH}} \approx{ }^{1} J_{\mathrm{BP}} 96 \mathrm{~Hz}\right) ;{ }^{13} \mathrm{C}\left\{{ }^{1} \mathrm{H}\right\}:$ $\delta_{\mathrm{C}}=11.71\left(\mathrm{~d},{ }^{1} \mathrm{~J}_{\mathrm{CP}} 48.1 \mathrm{~Hz}, \mathrm{CH}_{3}\right), 126.35\left[\mathrm{~d},{ }^{1} J_{\mathrm{CP}} 67.1 \mathrm{~Hz}, \mathrm{C}^{1}\left(\mathrm{C}_{6} \mathrm{H}_{5}\right)\right]$, $130.00\left[\mathrm{~m}, \mathrm{C}^{4}\left(\mathrm{C}_{6} \mathrm{H}_{5}\right)\right], 130.90\left[\mathrm{~m}, \mathrm{C}^{2,6}\left(\mathrm{C}_{6} \mathrm{H}_{5}\right)\right], 132.93\left[\mathrm{C}^{3,5}\left(\mathrm{C}_{6} \mathrm{H}_{5}\right)\right]$; ${ }^{31} \mathrm{P}\left\{{ }^{1} \mathrm{H}\right\}: \delta_{\mathrm{P}}=-3.5$ [q.br, ${ }^{1} \mathrm{JPB}_{\mathrm{PB}} 88 \mathrm{~Hz}$ (Average)]. NMR $\left(\mathrm{CDCl}_{3}, 25^{\circ} \mathrm{C}\right)$ : ${ }^{1} \mathrm{H}: \delta_{\mathrm{H}}=2.00\left(\mathrm{~d},{ }^{2} \mathrm{~J}_{\mathrm{PH}} 11.2 \mathrm{~Hz}, 12 \mathrm{H}, \mathrm{CH}_{3}\right), 7.50-7.56\left(\mathrm{~m}, 6 \mathrm{H}, \mathrm{C}_{6} \mathrm{H}_{5}\right)$, 7.64-7.67 (m, 4H, $\left.\mathrm{C}_{6} \mathrm{H}_{5}\right) ;{ }^{1} \mathrm{P}\left\{{ }^{1} \mathrm{H}\right\}: \delta_{\mathrm{p}}=-3.5$ [q.br, ${ }^{1}{ }_{\mathrm{PB}} 84 \mathrm{~Hz}$ (Average)]. Acc. Mass: Found: $m / z=289.1447$ Calcd. for $\mathrm{C}_{16} \mathrm{H}_{24}{ }^{11} \mathrm{BP}_{2}$ 289.1446 [M] ${ }^{+}$. ESI-MS (+ve ion): $\mathrm{m} / z=151.2$ $\left[\mathrm{M}-\mathrm{PMe}_{2} \mathrm{Ph}\right]^{+}$. Crystal data: $\mathrm{C}_{16} \mathrm{H}_{24} \mathrm{BBrP}_{2}, \mathrm{Mr}_{\mathrm{r}}=369.03, T=200$ (2) $\mathrm{K}$, monoclinic, space group $C c, a=12.5325(4), b=13.6104(5), c$ $=12.3150(3) \AA, \beta=119.5074(16)^{\circ}, V=1828.13(10) \AA^{3}, Z=4$, $D_{\text {calcd. }}=1.341 \mathrm{Mg} \mathrm{m}^{-3}, \mu($ Mo K $\alpha) 2.41 \mathrm{~mm}^{-1}$, colourless prism, $0.13 \times 0.16 \times 0.40 \mathrm{~mm}, 10394$ measured reflections with $2 \theta_{\max }$ $=55.0^{\circ}, 4040$ independent reflections, 4027 absorptioncorrected data used in $F^{2}$ refinement, 183 parameters, 2 restraints, $R_{1}=0.030, w R_{2}=0.060$ for 3496 reflections with $I>$ $2 \sigma(I)$.

Synthesis of $\left[\mathrm{H}_{2} \mathrm{~B}\left(\mathrm{PH}_{2} \mathrm{Cy}\right)(\mathrm{PHCy})\right] \mathrm{Br}$ (5). A solution of $\mathrm{BrH}_{2} \mathrm{~B} \cdot \mathrm{SMe}_{2}(1.0 \mathrm{M}, 0.50 \mathrm{~mL}, 0.5 \mathrm{mmol})$ in dichloromethane was added drop-wise to a stirred solution of dicyclohexylphosphine $\left(\rho=0.98 \mathrm{gcm}^{-3}, 0.10 \mathrm{~mL}, 0.5 \mathrm{mmol}\right)$ in DCM $(15 \mathrm{~mL})$ at $-78^{\circ} \mathrm{C}$. The mixture was stirred for $30 \mathrm{~min}$ at this temperature, then cyclohexylphosphine ( $\left.\rho=0.88 \mathrm{gcm}^{-3}, 0.07 \mathrm{~mL}, 0.5 \mathrm{mmol}\right)$ was added drop-wise. Stirred for $1 \mathrm{~h}$, after which all volatiles were removed under high vacuum to leave a yellow/orange oil. The complete disproportionation to $\left[\mathrm{H}_{2} \mathrm{~B}\left(\mathrm{PHCy}_{2}\right)_{2}\right] \mathrm{Br}$ and $\left[\mathrm{H}_{2} \mathrm{~B}\left(\mathrm{PH}_{2} \mathrm{Cy}\right)_{2}\right] \mathrm{Br}$ was observed to occur in $\angle 30 \mathrm{~min}$. NMR $\left(\mathrm{CD}_{2} \mathrm{Cl}_{2}\right.$, $\left.25^{\circ} \mathrm{C}\right):{ }^{1} \mathrm{H}: \delta_{\mathrm{H}}=1.26-2.22\left(\mathrm{~m}, 33 \mathrm{H}, \mathrm{C}_{6} \mathrm{H}_{11}\right), 5.61\left(\mathrm{~d},{ }^{1} \mathrm{~J}_{\mathrm{PH}} 418.7 \mathrm{~Hz}\right.$, $2 \mathrm{H}, \mathrm{PH} \mathrm{H}_{2} \mathrm{Cy}$ ), 5.76 (d, $\left.\left.{ }^{1} \mathrm{PH}_{\mathrm{PH}} 411.8 \mathrm{~Hz}, 1 \mathrm{H}, \mathrm{PHCy}\right)_{2}\right) ;{ }^{11} \mathrm{~B}\left\{{ }^{1} \mathrm{H}\right\}: \delta_{\mathrm{B}}=-45.1$ $\left\{\mathrm{br},\left[\mathrm{H}_{2} \mathrm{~B}\left(\mathrm{PH}_{2} \mathrm{Cy}\right)(\mathrm{PHCy})\right] \mathrm{Br}\right\},-27.3\left(\mathrm{br}, \mathrm{Cy}_{2} \mathrm{HP} \cdot \mathrm{BH}_{2} \mathrm{Br}\right),-20.7$ to $18.3(\mathrm{~m}) ;{ }^{31 \mathrm{P}}\left\{{ }^{1} \mathrm{H}\right\}: \delta_{\mathrm{P}}=-110.5$ (free $\mathrm{PH}_{2} \mathrm{Cy}$ ), -41.6 dd.br, ${ }^{2} \int_{\mathrm{PP}} 73 \mathrm{~Hz}$, $\left.\left[\mathrm{H}_{2} \mathrm{~B}\left(\mathrm{PH}_{2} \mathrm{Cy}\right)(\mathrm{PHCy} 2)\right] \mathrm{Br}\right\},-6.9,0.4\left\{\mathrm{br},\left[\mathrm{H}_{2} \mathrm{~B}\left(\mathrm{PH}_{2} \mathrm{Cy}\right)\left(\mathrm{PHCy}_{2}\right)\right] \mathrm{Br}\right\} ; ¥ ;$ ${ }^{31} \mathrm{P}: \delta_{\mathrm{P}}=-110.5$ (free $\mathrm{PH}_{2} \mathrm{Cy}$ ), $-41.5\left\{\mathrm{dt} . \mathrm{br},{ }^{1} J_{\mathrm{PH}} 375 \mathrm{~Hz}\right.$ (Average), $1 J_{\mathrm{PB}}$ unresolved, $\left.\left[\mathrm{H}_{2} \mathrm{~B}\left(\mathrm{PH}_{2} \mathrm{Cy}\right)(\mathrm{PHCy} 2)\right] \mathrm{Br}\right\}, 0.5$ ddd.br, ${ }^{1} J_{\mathrm{PH}} 401.5$ $\mathrm{Hz},{ }^{1} J_{\mathrm{PB}}$ unresolved, $\left.\left[\mathrm{H}_{2} \mathrm{~B}\left(\mathrm{PH}_{2} \mathrm{Cy}\right)(\mathrm{PHCy} 2)\right] \mathrm{Br}\right\}$. Acc. Mass: Found: $m / z=409.3328$ Calcd for $\mathrm{C}_{24} \mathrm{H}_{48}{ }^{11} \mathrm{BP}_{2} 409.3324[\mathrm{M}+$ $\left.\mathrm{PHCy}_{2}-\mathrm{PH}_{2} \mathrm{Cy}\right]^{+}$. ESI-MS (+ve ion): $m / z=327.3[\mathrm{M}+$ $\left.\mathrm{PH}_{2} \mathrm{Cy}-\mathrm{PHCy}_{2}\right]^{+}$.

Synthesis of $\left[\mathrm{H}_{2} \mathrm{~B}\left(\mathrm{PHCy}_{2}\right)\left(\mathrm{PHPh}_{2}\right)\right] \mathrm{Br}$ (6). A solution of $\mathrm{BrH}_{2} \mathrm{~B} \cdot \mathrm{SMe}_{2}(1.0 \mathrm{M}, 0.50 \mathrm{~mL}, 0.5 \mathrm{mmol})$ in dichloromethane was added drop-wise to a stirred solution of dicyclohexylphosphine $\left(\rho=0.98 \mathrm{gcm}^{-3}, 0.10 \mathrm{~mL}, 0.5 \mathrm{mmol}\right)$ in benzene $(10 \mathrm{~mL})$ that was cooled in an ice bath during addition. Stirring was continued for $5 \mathrm{~min}$, after which diphenylphosphine $\left(\rho=1.07 \mathrm{gcm}^{-3}, 0.09 \mathrm{~mL}\right.$, $0.5 \mathrm{mmol}$ ) was added drop-wise. The mixture was stirred for 5 min and then all volatiles were removed under high vacuum to leave an orange oil that was shown by NMR spectroscopy to comprise an approximate 2:1:1 mixture of $\left[\mathrm{H}_{2} \mathrm{~B}\left(\mathrm{PHCy}_{2}\right)\left(\mathrm{PHPh}_{2}\right)\right] \mathrm{Br},\left[\mathrm{H}_{2} \mathrm{~B}\left(\mathrm{PHCY}_{2}\right)_{2}\right] \mathrm{Br}$ and $\left[\mathrm{H}_{2} \mathrm{~B}\left(\mathrm{PHPh}_{2}\right)_{2}\right] \mathrm{Br}$. The complete disproportionation to $\left[\mathrm{H}_{2} \mathrm{~B}\left(\mathrm{PHCY}_{2}\right)_{2}\right] \mathrm{Br}$ and $\left[\mathrm{H}_{2} \mathrm{~B}\left(\mathrm{PHPh}_{2}\right)_{2}\right] \mathrm{Br}$ was observed to occur in $30-60 \mathrm{~min}$. NMR $\left(\mathrm{CD}_{2} \mathrm{Cl}_{2}, 25^{\circ} \mathrm{C}\right):{ }^{11} \mathrm{~B}\left\{{ }^{1} \mathrm{H}\right\}: \delta_{\mathrm{B}}=-44.6$ \{d.br, ${ }^{1} J_{\mathrm{BP}} 44 \mathrm{~Hz}$, $\left.\left[\mathrm{H}_{2} \mathrm{~B}\left(\mathrm{PHCy}_{2}\right)_{2}\right] \mathrm{Br}\right\},-40.5\left\{\mathrm{br},\left[\mathrm{H}_{2} \mathrm{~B}\left(\mathrm{PHCy}_{2}\right)\left(\mathrm{PHPh}_{2}\right)\right] \mathrm{Br}\right\},-27.2(\mathrm{br}$, 
$\left.\mathrm{BrH}_{2} \mathrm{Br} \cdot \mathrm{PHCy}{ }_{2}\right),-18.0(\mathrm{br}) ;{ }^{31} \mathrm{P}\left\{{ }^{1} \mathrm{H}\right\}: \delta_{\mathrm{P}}=-40.1\left(\right.$ free $\left.\mathrm{PHPh}_{2}\right),-21.2$ $\left\{d . b r,{ }^{2} J_{\mathrm{PP}} 303 \mathrm{~Hz},\left[\mathrm{H}_{2} \mathrm{~B}\left(\mathrm{PHCy}_{2}\right)\left(\mathrm{PHPh}_{2}\right)\right] \mathrm{Br}\right\},-3.2\left\{\mathrm{~d} . \mathrm{br},{ }^{2} J_{\mathrm{PP}} 220 \mathrm{~Hz}\right.$, $\left.\left[\mathrm{H}_{2} \mathrm{~B}\left(\mathrm{PHCy}_{2}\right)\left(\mathrm{PHPh}_{2}\right)\right] \mathrm{Br}\right\} ;{ }^{31} \mathrm{P}: \delta_{\mathrm{P}}=-39.1\left(\mathrm{br}\right.$, free $\left.\mathrm{PHPh}_{2}\right),-20.3$ \{dd.br, $\left.{ }^{1} J_{\mathrm{PH}} /{ }^{2} J_{\mathrm{PP}} 412 / 240 \mathrm{~Hz}, \quad\left[\mathrm{H}_{2} \mathrm{~B}\left(\mathrm{PHCY}_{2}\right)\left(\mathrm{PHPh}_{2}\right)\right] \mathrm{Br}\right\},-2.3$ \{dd.br, ${ }^{1} J_{\mathrm{PH}} /{ }^{2} J_{\mathrm{PP}} 463 / 289 \mathrm{~Hz},\left[\mathrm{H}_{2} \mathrm{~B}\left(\mathrm{PHCy}_{2}\right)\left(\mathrm{PHPh}_{2}\right)\right] \mathrm{Br}$ \}.

Synthesis of $\left[\mathrm{H}_{2} \mathrm{~B}\right.$ (dppe)]Br (7). ${ }^{9} \mathrm{~A}$ solution of $\mathrm{BrH}_{2} \mathrm{~B} . \mathrm{SMe}_{2}$ $(1.0 \mathrm{M}, 1.00 \mathrm{~mL}, 1.0 \mathrm{mmol})$ in dichloromethane was added dropwise to a stirred solution of dppe $(0.40 \mathrm{~g}, 1.0 \mathrm{mmol})$ in benzene $(15 \mathrm{~mL})$ that was cooled in an ice bath during addition. The mixture was allowed to warm to room temperature and stirred for $1.5 \mathrm{~h}$, after which time it was diluted with pentane to give a beige precipitate, which was isolated by filtration. The solid was dried under high vacuum for $19 \mathrm{~h}$ and recrystallised from a mixture of $\mathrm{DCM} /$ pentane at $25^{\circ} \mathrm{C}$ to provide colourless $\mathrm{X}$-ray diffraction quality crystals. Yield: $0.10 \mathrm{~g}(0.20 \mathrm{mmol}, 20 \%)$. M.p. $198-200^{\circ} \mathrm{C}$. The colourless crystals were finely ground and dried for several days in vacuo to obtain satisfactory microanalytical data. Anal. Found: C, 63.60; H, 5.39; N, 0.00\%. Calcd. for $\mathrm{C}_{26} \mathrm{H}_{26} \mathrm{BBrP}_{2}$ : C, 63.58; $\mathrm{H}, 5.34 ; \mathrm{N}, 0.00 \%$. NMR $\left(\mathrm{CDCl}_{3}, 25^{\circ} \mathrm{C}\right):{ }^{1} \mathrm{H}$ : $\delta_{\mathrm{H}}=3.43\left(\mathrm{~d},{ }^{2} \mathrm{~J}_{\mathrm{PH}} 9.6 \mathrm{~Hz}, 4 \mathrm{H}, \mathrm{CH}_{2}\right), 7.48-7.58\left[\mathrm{~m}, 12 \mathrm{H}, \mathrm{H}^{3,5}\left(\mathrm{C}_{6} \mathrm{H}_{5}\right)\right]$, 7.72-7.77 [m, 8H, $\left.\mathrm{H}^{2,6}\left(\mathrm{C}_{6} \mathrm{H}_{5}\right)\right] ;{ }^{11} \mathrm{~B}\left\{{ }^{1} \mathrm{H}\right\}: \delta_{\mathrm{B}}=-35.7(\mathrm{br}) ;{ }^{13} \mathrm{C}\left\{{ }^{1} \mathrm{H}\right\}: \delta_{\mathrm{C}}$ $=24.10\left(\mathrm{t}, J_{\mathrm{CP}} 24.7 \mathrm{~Hz}, \mathrm{CH}_{2}\right), 123.37\left[\mathrm{t}, J_{\mathrm{CP}} 35.4 \mathrm{~Hz}, \mathrm{C}^{1}\left(\mathrm{C}_{6} \mathrm{H}_{5}\right)\right]$, $129.78\left[\mathrm{t}, J_{\mathrm{CP}} 5.7 \mathrm{~Hz}, \mathrm{C}^{2,6}\left(\mathrm{C}_{6} \mathrm{H}_{5}\right)\right], 132.58\left[\mathrm{t}, J_{\mathrm{CP}} 5.1 \mathrm{~Hz}, \mathrm{C}^{3,5}\left(\mathrm{C}_{6} \mathrm{H}_{5}\right)\right]$, $133.20\left[\mathrm{C}^{4}\left(\mathrm{C}_{6} \mathrm{H}_{5}\right)\right] ;{ }^{11} \mathrm{P}\left\{{ }^{1} \mathrm{H}\right\}: \delta_{\mathrm{P}}=27.8(\mathrm{br})$. Acc. Mass: Found: $m / z$ $=$ 411.1604. Calcd. for $\mathrm{C}_{26} \mathrm{H}_{26}{ }^{11} \mathrm{BP}_{2} 411.1603$ [M] . Crystal data: $\left[\mathrm{C}_{26} \mathrm{H}_{26} \mathrm{BP}_{2}\right] \mathrm{Br} .0 .9 \mathrm{CH}_{2} \mathrm{Cl}_{2}, M_{\mathrm{r}}=566.96, T=200(2) \mathrm{K}$, monoclinic, space group $P 21 / n, a=12.8454(2), b=15.8917(3), c=$ 14.0831(3) $\AA, \beta=101.3055(11)^{\circ}, V=2819.07(9) \AA^{3}, Z=4, D_{\text {calcd. }}$ $=1.336 \mathrm{Mgm}^{-3}, \mu($ Mo K $\alpha) 1.75 \mathrm{~mm}^{-1}$, colourless block, $0.21 \times$ $0.22 \times 0.37 \mathrm{~mm}, 56899$ measured reflections with $2 \theta_{\max }=55.0^{\circ}$, 6480 independent reflections, 6465 absorption-corrected data used in $F^{2}$ refinement, 308 parameters, 10 restraints, $R_{1}=0.053$, $w R_{2}=0.154$ for 5240 reflections with $I>2 \sigma(I)$.

Synthesis of $\left[\mathrm{H}_{2} \mathrm{~B}(\mathrm{dcpe})\right]\left[\mathrm{HBBr}_{3}\right]$ (8). A solution of $\mathrm{BrH}_{2} \mathrm{~B} \cdot \mathrm{SMe}_{2}(1.0 \mathrm{M}, 0.50 \mathrm{~mL}, 0.50 \mathrm{mmol})$ in dichloromethane was added drop-wise to a stirred solution of dcpe $(0.21 \mathrm{~g}, 0.50$ $\mathrm{mmol})$ in benzene $(10 \mathrm{~mL})$ that was cooled in an ice bath during addition. The mixture was warmed to room temperature and slowly acquired an orange colour whilst being stirred for $5 \mathrm{~h}$. The mixture was freed of all volatiles under high vacuum to give an orange oil, which was recrystallised from a mixture of $\mathrm{DCM} /$ pentane at $25^{\circ} \mathrm{C}$, then isolated via cannula filtration to provide orange $\mathrm{X}$-ray diffraction quality crystals. X-ray crystallographic analysis confirmed the presence of the $\left[\mathrm{HBBr}_{3}\right]^{-}$ counter-ion, presumably due to the use of an aged sample of $\mathrm{BrH}_{2} \mathrm{~B} . \mathrm{SMe}_{2}$ that over time had become more concentrated than 1.0 M. Yield (based on dcpe): $0.244 \mathrm{~g}$ (0.47 mmol, 95\%). Anal. Found: $\mathrm{C}, 45.15 ; \mathrm{H}, 7.17 ; \mathrm{N}, 0.00 \%$. Calcd. for $\mathrm{C}_{26} \mathrm{H}_{51} \mathrm{~B}_{2} \mathrm{Br}_{3} \mathrm{P}_{2}$ : C, 45.46; $\mathrm{H}, 7.48 ; \mathrm{N}, 0.00 \%$. NMR $\left(\mathrm{CD}_{2} \mathrm{Cl}_{2}, 25^{\circ} \mathrm{C}\right)$ : ${ }^{1} \mathrm{H}: \delta_{\mathrm{H}}=1.35-2.04\left(\mathrm{~m}, 44 \mathrm{H}, \mathrm{C}_{6} \mathrm{H}_{11}\right), 2.31\left(\mathrm{~d},{ }^{2} \mathrm{~J}_{\mathrm{PH}} 6.0 \mathrm{~Hz}, 4 \mathrm{H}, \mathrm{CH}_{2}\right)$; ${ }^{11} \mathrm{~B}\left\{{ }^{1} \mathrm{H}\right\}: \delta_{\mathrm{B}}=-43.7\left(\mathrm{br}, \mathrm{P}_{2} \mathrm{BH}_{2}\right),-14.0\left(\left[\mathrm{HBBr}_{3}\right]^{-}\right) ;{ }^{11} \mathrm{~B}: \delta_{\mathrm{B}}=-43.7(\mathrm{br}$, $\left.\left.\mathrm{P}_{2} \mathrm{BH}_{2}\right),-14.0\left(\mathrm{~d},{ }^{1} J_{\mathrm{BH}}, 172 \mathrm{~Hz},\left[\mathrm{HBBr}_{3}\right]\right)^{-}\right) ;{ }^{13} \mathrm{C}\left\{{ }^{1} \mathrm{H}\right\}: \delta_{\mathrm{C}}=17.99\left(\mathrm{t}, J_{\mathrm{CP}}\right.$ $\left.21.6 \mathrm{~Hz}, \mathrm{CH}_{2}\right), 25.83\left[\mathrm{C}^{3,5}\left(\mathrm{C}_{6} \mathrm{H}_{11}\right)\right], 26.82\left[\mathrm{q}, J_{\mathrm{CP}} 6.3 \mathrm{~Hz}, \mathrm{C}^{4}\left(\mathrm{C}_{6} \mathrm{H}_{11}\right)\right]$, $27.55\left[\mathrm{~d}, J_{\mathrm{CP}} 16.4 \mathrm{~Hz}, \mathrm{C}^{2,6}\left(\mathrm{C}_{6} \mathrm{H}_{11}\right)\right.$ ], 31.62 [quin, $J_{\mathrm{CP}} 17.2 \mathrm{~Hz}$, $\left.\mathrm{C}^{1}\left(\mathrm{C}_{6} \mathrm{H}_{11}\right)\right] ;{ }^{31} \mathrm{P}\left\{{ }^{1} \mathrm{H}\right\}: \delta_{\mathrm{P}}=43.6\left(\right.$ d.br, $\left.{ }^{1} J_{\mathrm{PB}} 74 \mathrm{~Hz}\right)$. Acc. Mass: Found: $m / z=435.3482$. Calcd. for $\mathrm{C}_{26} \mathrm{H}_{50}{ }^{11} \mathrm{BP}_{2} 435.3481$ [M] ${ }^{+}$. Crystal data: $\left[\mathrm{C}_{26} \mathrm{H}_{50} \mathrm{BP}_{2}\right]\left[\mathrm{HBBr}_{3}\right], M_{\mathrm{r}}=686.97, T=200(2) \mathrm{K}$, monoclinic, space group $P 2_{1} / n, a=11.1381(1), b=12.5367(2), c=$
22.3536(3) $\AA, \beta=97.2547(8)^{\circ}, V=3096.36(7) \AA^{3}, Z=4, D_{\text {calcd }}=$ $1.474 \mathrm{Mgm}^{-3}, \mu($ Mo K $\alpha) 4.03 \mathrm{~mm}^{-1}$, colourless plate, $0.07 \times 0.16$ $\times 0.44 \mathrm{~mm}, 62272$ measured reflections with $2 \theta_{\max }=55.0^{\circ}$, 7097 independent reflections, 7079 absorption-corrected data used in $F^{2}$ refinement, 451 parameters, 176 restraints, $R_{1}=$ $0.045, w R_{2}=0.125$ for 5874 reflections with $I>2 \sigma(I)$.

Synthesis of $\left[\mathrm{H}_{2} \mathbf{B}(\mathbf{d m p e})\right] \mathrm{Br}$ (9). Neat dmpe $(0.17 \mathrm{~mL}, 1.0$ mmol) was added drop-wise to a stirred solution of $\mathrm{BrH}_{2} \mathrm{~B} . \mathrm{SMe}_{2}$ $(1.0 \mathrm{M}, 1.0 \mathrm{~mL}, 1.0 \mathrm{mmol})$ in dichloromethane and benzene (8 $\mathrm{mL}$ ), to instantaneously produce a white precipitate that did not settle. All volatiles were removed under high vacuum to leave a white powder. The product was found to be insoluble in most common solvents, which hindered complete characterisation. Yield: $0.177 \mathrm{~g}$ (0.73 mmol, 73\%). Anal. Found: C, 29.28; H, 7.35; $\mathrm{N}, 0.00 \%$. Calcd. for $\mathrm{C}_{6} \mathrm{H}_{18} \mathrm{BBrP}_{2}: \mathrm{C}, 29.67 ; \mathrm{H}, 7.47 ; \mathrm{N}, 0.00 \%$. $\operatorname{NMR}\left(\mathrm{D}_{6}\right.$-DMSO, $\left.25^{\circ} \mathrm{C}\right):{ }^{1} \mathrm{H}: \delta_{\mathrm{H}}=1.68\left(\mathrm{~d},{ }^{2} \mathrm{JHH}_{\mathrm{PH}} 11.7 \mathrm{~Hz}, 12 \mathrm{H}, \mathrm{CH}_{3}\right)$, $2.35\left(\mathrm{~d},{ }^{2} \mathrm{~J}_{\mathrm{PH}} 9.3 \mathrm{~Hz}, 4 \mathrm{H}, \mathrm{CH}_{2}\right) ;{ }^{11} \mathrm{~B}\left\{{ }^{1} \mathrm{H}\right\}: \delta_{\mathrm{B}}=-34.5(\mathrm{br}) ;{ }^{11} \mathrm{~B}: \delta_{\mathrm{B}}=-$ $34.5\left[\mathrm{t},{ }^{1} J_{\mathrm{BH}}, 78 \mathrm{~Hz}\right.$ ]; ${ }^{31} \mathrm{P}\left\{{ }^{1} \mathrm{H}\right\}: \delta_{\mathrm{P}}=20.3$ (d.br, ${ }^{1}{ }_{\mathrm{PB}} 96 \mathrm{~Hz}$ ). Acc. Mass: Found: $m / z=163.0977$. Calcd for $\mathrm{C}_{6} \mathrm{H}_{18}{ }^{11} \mathrm{BP}_{2} 163.0977$ $[\mathrm{M}]^{+}$.

Synthesis of $\left[\mathrm{H}_{2} \mathrm{~B}(\mathrm{dppf})\right] \mathrm{Br}(\mathbf{1 0 )})$ A solution of $\mathrm{BrH}_{2} \mathrm{~B} . \mathrm{SMe}_{2}$ $(1.0 \mathrm{M}, 0.20 \mathrm{~mL}, 0.20 \mathrm{mmol})$ in dichloromethane was added drop-wise to a stirred solution of dppf $(0.11 \mathrm{~g}, 0.20 \mathrm{mmol})$ in toluene $(10 \mathrm{~mL})$ and heated to reflux for $16 \mathrm{~h}$, which resulted in a pale orange precipitate and an orange solution (found to contain the mono-adduct $\mathrm{BrH}_{2} \mathrm{~B} \cdot \mathrm{dppf}$ ). The precipitate was separated by cannula filtration. The solid was dissolved in DCM and precipitated by addition of pentane to give a pale orange solid that was dried under high vacuum. Yield $0.048 \mathrm{~g}(0.074$ mmol, 37\%). ${ }^{11} \mathrm{~B}\left\{{ }^{1} \mathrm{H}\right\}: \delta_{\mathrm{B}}=-27.4(\mathrm{br}) ;{ }^{13} \mathrm{C}\left\{{ }^{1} \mathrm{H}\right\}: \delta_{\mathrm{C}}=67.38\left[\mathrm{~d},{ }^{1} J_{\mathrm{CP}}\right.$ $\left.83.5 \mathrm{~Hz}, \mathrm{C}^{1}\left(\mathrm{C}_{5} \mathrm{H}_{4}\right)\right], 83.92\left(\mathrm{C}_{5} \mathrm{H}_{4}\right), 84.59\left(\mathrm{C}_{5} \mathrm{H}_{4}\right), 125.06\left[\mathrm{~d},{ }^{1} \mathrm{CP}_{\mathrm{CP}} 70.2\right.$ $\left.\mathrm{Hz}, \mathrm{C}^{1}\left(\mathrm{C}_{6} \mathrm{H}_{5}\right)\right], 133.31\left(\mathrm{C}_{6} \mathrm{H}_{5}\right), 134.79\left(\mathrm{C}_{6} \mathrm{H}_{5}\right), 135.54\left(\mathrm{C}_{6} \mathrm{H}_{5}\right)$; ${ }^{31} \mathrm{P}\left\{{ }^{1} \mathrm{H}\right\}: \delta_{\mathrm{P}}=9.7(\mathrm{br})$. Acc. Mass: Found: $m / z=567.1265$ Calcd. for $\mathrm{C}_{34} \mathrm{H}_{30} 0^{11} \mathrm{~B}^{56} \mathrm{FeP}_{2} 567.1265[\mathrm{M}-\mathrm{Br}]^{+}$.

Synthesis of $\left[\mathrm{H}_{2} \mathrm{~B}(\mathrm{dppf})\right]\left[\mathrm{AsF}_{6}\right]$ (11). A solution of $\left[\mathrm{H}_{2} \mathrm{~B}\right.$ (dppf)]Br (0.142 $\left.\mathrm{g}, 0.22 \mathrm{mmol}\right)$ in $\mathrm{DCM}(15 \mathrm{~mL})$ was transferred via cannula into a THF $(15 \mathrm{~mL})$ solution of $\mathrm{K}$ [AsF 6 ] $(0.050 \mathrm{~g}, 0.25 \mathrm{mmol})$ to instantaneously form a white precipitate $(\mathrm{KBr})$ that was stirred for $15 \mathrm{~min}$. The filtrate was separated via cannula filtration and all volatiles were removed under high vacuum to leave an orange solid. The solid was recrystallised from a mixture of DCM/pentane to produce orange X-ray diffraction quality crystals. Yield $0.101 \mathrm{~g}(0.13$ mmol, 61\%). Satisfactory elemental analysis could not be obtained due to compound partially undergoing decomposition to $\left[\mathrm{H}_{2} \mathrm{~B}(\mathrm{dppf})_{2}\right]\left[\mathrm{FeBr}_{4}\right]$. NMR $\left(\mathrm{CDCl}_{3}, 25^{\circ} \mathrm{C}\right):{ }^{1} \mathrm{H}: \delta_{\mathrm{H}}=3.13$ (q.br, $\left.{ }^{1} \mathrm{~J}_{\mathrm{BH}} 128 \mathrm{~Hz}, 2 \mathrm{H}, \mathrm{BH}_{2}\right), 4.68\left(\mathrm{~s}, 4 \mathrm{H}, \mathrm{C}_{5} \mathrm{H}_{4}\right), 4.77\left(\mathrm{~s}, 4 \mathrm{H}, \mathrm{C}_{5} \mathrm{H}_{4}\right), 7.49$ $\left(\mathrm{s}, 8 \mathrm{H}, \mathrm{C}_{6} \mathrm{H}_{5}\right), 7.65\left(\mathrm{~s}, 12 \mathrm{H}, \mathrm{C}_{6} \mathrm{H}_{5}\right) ;{ }^{11} \mathrm{~B}\left\{{ }^{1} \mathrm{H}\right\}: \delta_{\mathrm{B}}=-28.1$ (s.br); ${ }^{13} \mathrm{C}\left\{{ }^{1} \mathrm{H}\right\}: \delta_{\mathrm{C}}=67.58\left[\mathrm{~d},{ }^{1} J_{\mathrm{CP}} 63.4 \mathrm{~Hz}, \mathrm{C}^{1}\left(\mathrm{C}_{5} \mathrm{H}_{4}\right)\right], 76.62\left(\mathrm{C}_{5} \mathrm{H}_{4}\right), 76.97$ $\left(\mathrm{C}_{5} \mathrm{H}_{4}\right), 125.44\left[\mathrm{~d},{ }^{1} \mathrm{~J}_{\mathrm{CP}} 70.8 \mathrm{~Hz}, \mathrm{C}^{1}\left(\mathrm{C}_{6} \mathrm{H}_{5}\right)\right], 130.60\left(\mathrm{C}_{6} \mathrm{H}_{5}\right), 133.54$ $\left(\mathrm{C}_{6} \mathrm{H}_{5}\right), 133.87\left(\mathrm{C}_{6} \mathrm{H}_{5}\right) ;{ }^{11} \mathrm{P}\left\{{ }^{1} \mathrm{H}\right\}: \delta_{\mathrm{p}}=-8.22$ (s.br). Acc. Mass: Found: $m / z=567.1265$ Calcd. for $\mathrm{C}_{34} \mathrm{H}_{30}{ }^{11} \mathrm{~B}^{56} \mathrm{FeP}_{2} 567.1265$ $[\mathrm{M}]^{+}$. ESI-MS (-ve ion): $\mathrm{m} / z=416.8\left[2\left(\mathrm{AsF}_{6}\right)+\mathrm{K}\right]^{-}, 400.8\left[2\left(\mathrm{AsF}_{6}\right)\right.$ $+\mathrm{Na}]^{-}, 188.9\left[\mathrm{AsF}_{6}\right]^{-}$. Crystal data: $\left[\mathrm{C}_{34} \mathrm{H}_{30} \mathrm{BFeP}_{2}\right]\left[\mathrm{AsF}_{6}\right], M_{\mathrm{r}}=$ 756.13, $T=150(2) \mathrm{K}$, triclinic, space group $P-1$ (No.2), $a=$ 10.3352(2), $b=10.6422(2), c=15.0052(4) \AA, \alpha=74.012(2), \beta=$ $85.306(2), \gamma=89.514(2)^{\circ}, V=1581.06(8) \AA^{3}, Z=2, D_{\text {calcd. }}=1.588$ $\mathrm{Mg} \mathrm{m}^{-3}, \mu(\mathrm{Cu} \mathrm{K} \alpha) 6.47 \mathrm{~mm}^{-1}$, orange plate, $0.08 \times 0.18 \times 0.27$ 
$\mathrm{mm}, 17516$ measured reflections with $2 \theta_{\max }=144.6^{\circ}, 6249$ independent reflections, 6249 absorption-corrected data used in $F^{2}$ refinement, 407 parameters, no restraints, $R_{1}=0.026, w R_{2}$ $=0.071$ for 6144 reflections with $I>2 \sigma(I)$.

Synthesis of $\left[\mathrm{H}_{2} \mathrm{~B}(\mathrm{dppf})\right]\left[\mathrm{FeBr}_{4}\right]$. Crystal data: $\left[\mathrm{C}_{34} \mathrm{H}_{30} \mathrm{BFeP}_{2}\right]\left[\mathrm{FeBr}_{4}\right], M_{\mathrm{r}}=942.68, T=150(2) \mathrm{K}$, monoclinic, space group $P 2_{1} / n, a=9.5194(1), b=15.9813(1), c=23.6291(1)$ $\AA ̊ 丿, \beta=93.1146(4)^{\circ}, V=3589.44(5) \AA^{3}, Z=4, D_{\text {calcd }}=1.744 \mathrm{Mg} \mathrm{m}$ 3, $\mu(\mathrm{Cu} \mathrm{K} \alpha)=12.71 \mathrm{~mm}^{-1}$, dark red block, $0.07 \times 0.09 \times 0.15 \mathrm{~mm}$, 70155 measured reflections with $2 \theta_{\max }=144.8^{\circ}, 7092$ independent reflections, 7091 absorption-corrected data used in $F^{2}$ refinement, 388 parameters, no restraints, $R_{1}=0.032, w R_{2}$ $=0.087$ for 6930 reflections with $I>2 \sigma(I)$.

Synthesis of $\left[\mathrm{H}_{2} \mathrm{~B}\right.$ (amphos)]Br (12). A solution of $\mathrm{BrH}_{2} \mathrm{~B} . \mathrm{SMe}_{2}(1.0 \mathrm{M}, 0.50 \mathrm{~mL}, 0.50 \mathrm{mmol})$ in dichloromethane was added drop-wise to a stirred solution of amphos $(0.15 \mathrm{~g}$, $0.50 \mathrm{mmol}$ ) in DCM ( $2 \mathrm{~mL}$ ). The mixture was stirred for $1 \mathrm{~h}$, after which all volatiles were removed under high vacuum to leave a white solid. The solid was dissolved in DCM and precipitated by addition of pentane to give a white precipitate that was separated via cannula filtration. The solid was recrystallised from a mixture of DCM/pentane to produce colourless X-ray diffraction quality crystals. Yield $0.185 \mathrm{~g}(0.46 \mathrm{mmol}, 93 \%)$. Anal. Found: $\mathrm{C}, 53.07 ; \mathrm{H}, 5.00: \mathrm{N}, 3.22 \%$. Calcd for $\mathrm{C}_{20} \mathrm{H}_{22} \mathrm{BBrNP} .0 .9\left(\mathrm{CH}_{2} \mathrm{Cl}_{2}\right): \mathrm{C}, 52.90 ; \mathrm{H}, 5.06 ; \mathrm{N}, 2.95 \%$. NMR $\left(\mathrm{CDCl}_{3}, 25^{\circ} \mathrm{C}\right):{ }^{1} \mathrm{H}: \delta_{\mathrm{H}}=3.46\left(\mathrm{~s}, 6 \mathrm{H}, \mathrm{NMe}_{2}\right), 7.53-7.71(\mathrm{~m}, 12 \mathrm{H}$, $\left.\mathrm{C}_{6} \mathrm{H}_{5}\right), 7.94-8.00\left(\mathrm{~m}, 1 \mathrm{H}, \mathrm{C}_{6} \mathrm{H}_{4}\right), 8.90\left(\mathrm{dd}, J_{\mathrm{PH}} / J 8.4 \mathrm{~Hz} / 3.9 \mathrm{~Hz}, 1 \mathrm{H}\right.$, $\left.\mathrm{C}_{6} \mathrm{H}_{4}\right) ;{ }^{11} \mathrm{~B}\left\{{ }^{1} \mathrm{H}\right\}: \delta_{\mathrm{B}}=-9.3(\mathrm{br}) ;{ }^{13} \mathrm{C}\left\{{ }^{1} \mathrm{H}\right\}: \delta_{\mathrm{C}}=57.51\left(\mathrm{~d},{ }^{2} J_{\mathrm{BC}} 4.6 \mathrm{~Hz}\right.$, $\left.\mathrm{NMe}_{2}\right), 119.85\left[\mathrm{~d},{ }^{1} J_{\mathrm{CP}} 62.1 \mathrm{~Hz}, \mathrm{C}^{1}\left(\mathrm{C}_{6} \mathrm{H}_{5}\right)\right], 121.12\left[\mathrm{~d},{ }^{1} J_{\mathrm{CP}} 69.1 \mathrm{~Hz}\right.$, $\left.\mathrm{C}^{1}\left(\mathrm{C}_{6} \mathrm{H}_{4}\right)\right], 123.86$ (d, $J_{\mathrm{CP}} 8.0 \mathrm{~Hz}$ ), 130.29 (d, $J_{\mathrm{CP}} 11.5 \mathrm{~Hz}$ ), 131.46 (d, $J_{\mathrm{CP}} 6.9 \mathrm{~Hz}$ ), 132.04, 133.12 (d, J $\left.J_{\mathrm{CP}} 10.3 \mathrm{~Hz}\right), 133.89$ (d, J 2.3 $\mathrm{Hz}), 137.17,155.52\left[\mathrm{~d},{ }^{2} J_{\mathrm{CP}} 49.5 \mathrm{~Hz}, \mathrm{C}^{2}\left(\mathrm{C}_{6} \mathrm{H}_{4}\right)\right] ;{ }^{31} \mathrm{P}\left\{{ }^{1} \mathrm{H}\right\}: \delta_{\mathrm{P}}=4.5$ (br). Acc. Mass: Found: $m / z=318.1585$ Calcd for $\mathrm{C}_{20} \mathrm{H}_{22}{ }^{11} \mathrm{BNP}$ $318.1583[\mathrm{M}]^{+}$. Crystal data: $\mathrm{C}_{20} \mathrm{H}_{22} \mathrm{BBrNP}, \mathrm{Mr}_{\mathrm{r}}=398.09, T=$ 200(2) K, monoclinic, space group $P 2_{1} / n, a=9.5770(2), b=$ 7.3405(1), $c=27.7205(5) \AA, \beta=98.4547(10)^{\circ}, V=1927.57(6) \AA^{3}$, $Z=4, D_{\text {calcd }}=1.372 \mathrm{Mg} \mathrm{m}^{-3}, \mu(\mathrm{Mo} \mathrm{K} \alpha)=2.22 \mathrm{~mm}^{-1}$, colourless plate, $0.04 \times 0.17 \times 0.24 \mathrm{~mm}, 31237$ measured reflections with $2 \theta_{\max }=55.0^{\circ}, 4427$ independent reflections, 4425 absorptioncorrected data used in $F^{2}$ refinement, 305 parameters, no restraints, $R_{1}=0.033, w R_{2}=0.082$ for 3637 reflections with $I>$ $2 \sigma(I)$.

Reaction of dcpe with $\mathrm{Br}_{2} \mathrm{HB} \cdot \mathrm{SMe}_{2}$ : Observation of [BrHB(dcpe)] $\mathrm{Br}(13)$ and isolation of $\left(\mathrm{Br}_{2} \mathrm{HB}\right)_{2} \cdot$ dcpe: A solution of $\mathrm{Br}_{2} \mathrm{HB} . \mathrm{SMe}_{2}(1.0 \mathrm{M}, 0.25 \mathrm{~mL}, 0.25 \mathrm{mmol})$ in dichloromethane was added drop-wise to a stirred solution of dcpe $(0.11 \mathrm{~g}, 0.25$ $\mathrm{mmol}$ ) in benzene $(5 \mathrm{~mL})$ that was cooled in an ice bath during addition. The mixture was warmed to room temperature and stirred for $6 \mathrm{~h}$, during which time the solution acquired a fine precipitate. All volatiles were removed under high vacuum to leave a white residue. The residue was recrystallized from a mixture of $\mathrm{DCM} /$ pentane at $-15^{\circ} \mathrm{C}$ to provide colourless $\mathrm{X}$-ray diffraction quality crystals of $[\mathrm{BrHB}(\mathrm{dcpe})] \mathrm{Br}$. The residue remaining after removal of $[\mathrm{BrHB}(\mathrm{dcpe})] \mathrm{Br}$ was recrystallised from a mixture of DCM/ethanol to provide colourless X-ray diffraction quality crystals of dcpe $\left(\mathrm{BHBr}_{2}\right)_{2}$. Crude mixture contained approximately a 1:1 stoichiometry of the two products based on NMR integration.

[BrHB(dcpe)]Br (13). Anal. Found: C, 47.76; H, 7.50; N, 0.00\%. Calcd. for $\mathrm{C}_{26} \mathrm{H}_{26} \mathrm{BBrP}_{2} . \mathrm{CH}_{2} \mathrm{Cl}_{2}: \mathrm{C}, 47.75 ; \mathrm{H}, 7.57 ; \mathrm{N}, 0.00 \%$. NMR $\left(\mathrm{CD}_{2} \mathrm{Cl}_{2}, 25^{\circ} \mathrm{C}\right):{ }^{11} \mathrm{~B}\left\{{ }^{1} \mathrm{H}\right\}: \delta_{\mathrm{B}}=-26.8(\mathrm{br}) ;{ }^{1} \mathrm{P}\left\{{ }^{1} \mathrm{H}\right\}: \delta_{\mathrm{P}}=20.9$ (d.br, $\left.1_{\mathrm{PB}} 89 \mathrm{~Hz}\right)$. Acc. Mass: Found: $\mathrm{m} / \mathrm{z}=513.2585$ Calcd. for $\mathrm{C}_{26} \mathrm{H}_{49}{ }^{11} \mathrm{~B}^{79} \mathrm{BrP}_{2}$ 513.2586 [M] ${ }^{+}$. ESI-MS (+ve ion): $\mathrm{m} / z=435.6$ [M $+\mathrm{H}-\mathrm{Br}]^{+}$. Crystal data: $2\left(\left[\mathrm{C}_{26} \mathrm{H}_{49} \mathrm{BBrP} \mathrm{Brr}_{2}\right] \cdot \mathrm{CH}_{2} \mathrm{Cl}_{2}, \mathrm{M}_{\mathrm{r}}=1273.41\right.$, $T=200(2) \mathrm{K}$, triclinic, space group $P-1$ (No.2), $a=11.8318(3), b$ $=13.6868(3), \quad c=20.5375(4) \AA, \alpha=102.0817(13), \beta=$ 99.8011(10), $\gamma=92.5268(11)^{\circ}, V=3193.71(13) \AA^{3}, Z=2, D_{\text {calcd. }}=$ $1.324 \mathrm{Mg} \mathrm{m}^{-3}, \mu(\mathrm{Mo} \mathrm{K} \alpha) 2.74 \mathrm{~mm}^{-1}$, colourless block, $0.16 \times 0.17$ $\times 0.28 \mathrm{~mm}, 66125$ measured reflections with $2 \theta_{\max }=55.0^{\circ}$, 14614 independent reflections, 14574 absorption-corrected data used in $F^{2}$ refinement, 586 parameters, 247 restraints, $R_{1}=$ $0.047, w R_{2}=0.132$ for 10760 reflections with $I>2 \sigma(I)$.

$\left(\mathrm{Br}_{2} \mathrm{HB}\right)_{2} \cdot$ dcpe. Anal. Found: $\mathrm{C}, 40.75 ; \mathrm{H}, 6.64 ; \mathrm{N}, 0.00 \%$. Calcd. for $\mathrm{C}_{26} \mathrm{H}_{50} \mathrm{~B}_{2} \mathrm{Br}_{4} \mathrm{P}_{2}$ : C, 40.78; $\mathrm{H}, 6.58 ; \mathrm{N}, 0.00 \%$. NMR $\left(\mathrm{CD}_{2} \mathrm{Cl}_{2}\right.$, $\left.25^{\circ} \mathrm{C}\right):{ }^{11} \mathrm{~B}\left\{{ }^{1} \mathrm{H}\right\}: \delta_{\mathrm{B}}=-17.6(\mathrm{br}) ;{ }^{1} \mathrm{P}\left\{{ }^{1} \mathrm{H}\right\}: \delta_{\mathrm{P}}=0.1(\mathrm{br})$. Crystal data: $\mathrm{C}_{26} \mathrm{H}_{50} \mathrm{~B}_{2} \mathrm{Br}_{4} \mathrm{P}_{2}, M_{\mathrm{r}}=765.87, T=273(2) \mathrm{K}$ (crystals found to crack at 200K), monoclinic, space group $C 2 / c, a=18.4285(7), b=$ 8.5936(3), $c=20.9657(8) \AA, \beta=94.666(2)^{\circ}, V=3309.3(2) \AA^{3}, Z$ $=4, D_{\text {calcd. }}=1.537 \mathrm{Mg} \mathrm{m}^{-3}, \mu($ Mo K $\alpha) 4.98 \mathrm{~mm}^{-1}$, colourless prism, $0.04 \times 0.07 \times 0.16 \mathrm{~mm}, 22553$ measured reflections with $2 \theta_{\max }$ $=50.0^{\circ}, 2903$ independent reflections, 2903 absorptioncorrected data used in $F^{2}$ refinement, 155 parameters, 119 restraints, $R_{1}=0.065, w R_{2}=0.182$ for 2052 reflections with $I>$ $2 \sigma(I)$.

Synthesis of $\left[\mathrm{BrHB}\left(\mathrm{PMe}_{2} \mathrm{Ph}\right)_{2}\right] \mathrm{Br}$ (14). A solution of $\mathrm{Br}_{2} \mathrm{HB}_{\mathrm{SMe}}(1.0 \mathrm{M}, 1.00 \mathrm{~mL}, 1.00 \mathrm{mmol})$ in dichloromethane was added drop-wise to a stirred solution of dimethylphenylphosphine ( $\rho=0.97 \mathrm{gcm}^{-3}, 0.28 \mathrm{~mL}, 2.00 \mathrm{mmol}$ ) in pentane $(4 \mathrm{~mL})$. The solution went cloudy at the beginning of the addition, but became less opaque as a colourless oil separated out beneath the solvent layer. After $2 \mathrm{~h}$ stirring, all volatiles were removed under high vacuum to leave a colourless oil, which was dried for an additional $2 \mathrm{~h}$ in vacuo. The compound was observed to decompose over a short period of time ( $4 \mathrm{~h})$. Yield $0.42 \mathrm{~g}(0.94 \mathrm{mmol}, 94 \%)$. NMR (Crude, $\mathrm{CD}_{2} \mathrm{Cl}_{2}$, $\left.25^{\circ} \mathrm{C}\right):{ }^{11} \mathrm{~B}\left\{{ }^{1} \mathrm{H}\right\}: \delta_{\mathrm{B}}=-21.5(\mathrm{br}) ;{ }^{31} \mathrm{P}\left\{{ }^{1} \mathrm{H}\right\}: \delta_{\mathrm{P}}=-7.5\left(\mathrm{~d} \cdot \mathrm{br},{ }^{1} \mathrm{JPB}_{\mathrm{PB}} 134 \mathrm{~Hz}\right)$. Acc. Mass: Found: $m / z=367.0550$. Calcd. for $\mathrm{C}_{16} \mathrm{H}_{23}{ }^{11} \mathrm{~B}^{79} \mathrm{BrP}$ $367.0551[\mathrm{M}]^{+}$.

Synthesis of [BrHB(amphos)]Br (15). A solution of $\mathrm{Br}_{2} \mathrm{HB} \cdot \mathrm{SMe}_{2}(1.0 \mathrm{M}, 0.50 \mathrm{~mL}, 0.50 \mathrm{mmol})$ in dichloromethane was added drop-wise to a stirred solution of 1diphenylphosphino-2-dimethylaminophenylene $(0.15 \mathrm{~g}, 0.50$ $\mathrm{mmol})$ in DCM $(2 \mathrm{~mL})$ and stirred for $1.5 \mathrm{~h}$. All volatiles were removed under high vacuum to leave an off-white solid. The solid was recrystallised from a mixture of DCM/pentane overnight to produce colourless $\mathrm{X}$-ray diffraction quality crystals. Yield: $0.201 \mathrm{~g}(0.42 \mathrm{mmol}, 84 \%)$. Anal. Found: C, 33.70; $\mathrm{H}, 2.06: \mathrm{N}, 1.69 \%$. Calcd. for $\mathrm{C}_{20} \mathrm{H}_{21} \mathrm{BBr}_{2} \mathrm{NP} .2\left(\mathrm{CHCl}_{3}\right): \mathrm{C}, 36.92 ; \mathrm{H}$, 3.24; N, 1.96\% ${ }^{\ddagger \ddagger} \mathrm{NMR}\left(\mathrm{CDCl}_{3}, 25^{\circ} \mathrm{C}\right):{ }^{1} \mathrm{H}: \delta_{\mathrm{H}}=3.24$ (s, 3H, NMe), $3.77(\mathrm{~d}, 1.8 \mathrm{~Hz}, 3 \mathrm{H}, \mathrm{NMe}), 7.57-7.81\left(\mathrm{~m}, 12 \mathrm{H}, \mathrm{C}_{6} \mathrm{H}_{4} / \mathrm{C}_{6} \mathrm{H}_{5}\right), 8.13$ [t, $8 \mathrm{~Hz}, 1 \mathrm{H}, \mathrm{C}_{6} \mathrm{H}_{4}$ ] $\left., 9.14\left(\mathrm{dd}, \mathrm{J}_{\mathrm{PH}} / \mathrm{J} 8 / 5 \mathrm{~Hz}\right), 1 \mathrm{H}, \mathrm{C}_{6} \mathrm{H}_{4}\right] ;{ }^{11} \mathrm{~B}\left\{{ }^{1} \mathrm{H}\right\}: \delta_{\mathrm{B}}$ $=-5.2(\mathrm{br}) ;{ }^{13} \mathrm{C}\left\{{ }^{1} \mathrm{H}\right\}: \delta_{\mathrm{C}}=53.57$ (NMe), 55.45 (NMe), $117.23[\mathrm{~d}$, $\left.{ }^{1} J_{\mathrm{CP}} 65.2 \mathrm{~Hz}, \mathrm{C}^{1}\left(\mathrm{C}_{6} \mathrm{H}_{5}\right)\right], 118.35\left[\mathrm{~d},{ }^{1} J_{\mathrm{CP}} 69.4 \mathrm{~Hz}, \mathrm{C}^{1}\left(\mathrm{C}_{6} \mathrm{H}_{4}\right)\right], 119.18$ 
[d, ${ }^{1} J_{\mathrm{CP}} 75.5 \mathrm{~Hz}, \mathrm{C}^{1}\left(\mathrm{C}_{6} \mathrm{H}_{5}\right)$ ], 124.30, 125.05 (d, $\left.J_{\mathrm{CP}} 6.8 \mathrm{~Hz}\right), 129.31$, 130.05, 130.57 (dd, $J_{C P} / J 11.9 \mathrm{~Hz} / 4.2 \mathrm{~Hz}$ ), 132.09 (d, $J_{\mathrm{CP}} 7.6 \mathrm{~Hz}$ ), 132.91, 133.52 (d, $\left.J_{C P} 10.2 \mathrm{~Hz}\right), 133.74\left(d, J_{C P} 9.3 \mathrm{~Hz}\right), 134.58$ (d, $\left.J_{\mathrm{CP}} 11.9 \mathrm{~Hz}\right), 138.49,154.44\left[\mathrm{~d},{ }^{2} J_{\mathrm{CP}} 17.0 \mathrm{~Hz}, \mathrm{C}^{2}\left(\mathrm{C}_{6} \mathrm{H}_{4}\right)\right] ;{ }^{31 \mathrm{P}}\left\{{ }^{1} \mathrm{H}\right\}: \delta_{\mathrm{P}}$ $=-11.0$ (br). Acc. Mass: Found: $m / z=396.0686$ Calcd. for $\mathrm{C}_{20} \mathrm{H}_{21}{ }^{11} \mathrm{~B}^{79} \mathrm{BrNP} \quad 396.0688 \quad[\mathrm{M}]^{+}$. Crystal data: $\mathrm{C}_{20} \mathrm{H}_{21} \mathrm{BBr}_{2}$ NP.2 $\left(\mathrm{CHCl}_{3}\right), M_{\mathrm{r}}=715.74, T=200(2) \mathrm{K}$, monoclinic, space group $P 2_{1} / a, a=14.6204(2), b=14.0880(3), c=$ $14.7554(3) \AA, \beta=109.0115(15)^{\circ}, V=2873.42(10) \AA^{3}, Z=4, D_{\text {calcd. }}$ $=1.654 \mathrm{Mg} \mathrm{m}^{-3}, \mu($ Mo K $\alpha)=3.45 \mathrm{~mm}^{-1}$, colourless block, $0.16 \times$ $0.28 \times 0.29 \mathrm{~mm}, 52435$ measured reflections with $2 \theta_{\max }=55.0^{\circ}$, 6590 independent reflections, 6590 absorption-corrected data used in $F^{2}$ refinement, 298 parameters, no restraints, $R_{1}=0.043$, $w R_{2}=0.102$ for 4632 reflections with $I>2 \sigma(I)$.

Synthesis of $\left[\mathrm{H}_{2} \mathrm{~B}\right.$ (diphars) $\mathrm{Br}(\mathbf{1 6})$. A solution of $\mathrm{BrH}_{2} \mathrm{~B} \cdot \mathrm{SMe}_{2}$ $(1.0 \mathrm{M}, 0.50 \mathrm{~mL}, 0.50 \mathrm{mmol})$ in dichloromethane was added drop-wise to a stirred suspension of 1,2-bis(phenyl(2'diphenylarsinoethyl)phosphino)ethane $(0.38 \mathrm{~g}, 0.50 \mathrm{mmol})$ in toluene $(30 \mathrm{~mL})$ at $0^{\circ} \mathrm{C}$. Upon addition the suspension turned a lime green colour, and after 5 min stirring the reaction was warmed to ambient temperature during which time it developed a mustard yellow colour. After 30 min stirring, all material had dissolved. The mixture was stirred for $14 \mathrm{~h}$, and then reduced to a third of the volume under high vacuum and diluted with pentane. The resulting precipitate was isolated by cannula filtration to leave a beige solid that was recrystallised from a mixture of DCM/pentane. The solid was further recrystallized from a mixture of $\mathrm{DCM} /$ pentane at $-15^{\circ} \mathrm{C}$ over 72 $\mathrm{h}$ to produce colourless $\mathrm{X}$-ray diffraction quality crystals. Yield $0.31 \mathrm{~g}(0.36 \mathrm{mmol}, 73 \%)$. The appearance changed at $92^{\circ} \mathrm{C}$ to more opaque solid, followed by gas evolution at $210^{\circ} \mathrm{C}$ to become a viscous oil which turned brown and solidified at $238^{\circ} \mathrm{C}$. Anal. Found: $\mathrm{C}, 54.78 ; \mathrm{H}, 4.86 ; \mathrm{N}, 0.00 \%$. Calcd. for $\mathrm{C}_{42} \mathrm{H}_{44} \mathrm{As}_{2} \mathrm{BBrP}_{2} . \mathrm{CH}_{2} \mathrm{Cl}_{2}: \mathrm{C}, 55.16 ; \mathrm{H}, 4.95 ; \mathrm{N}, 0.00 \%$. NMR $\left(\mathrm{CD}_{2} \mathrm{Cl}_{2}\right.$, $\left.25^{\circ} \mathrm{C}\right):{ }^{1} \mathrm{H}: \delta_{\mathrm{H}}=1.92-1.98\left(\mathrm{~m}, 4 \mathrm{H}, \mathrm{PCH}_{2}\right), 2.08-2.14\left(\mathrm{~m}, 4 \mathrm{H}, \mathrm{PCH}_{2}\right)$, 2.46-2.48 (m, $\left.4 \mathrm{H}, \mathrm{AsCH}_{2}\right)$, 7.24-7.31 (m, $\left.12 \mathrm{H}, \mathrm{C}_{6} \mathrm{H}_{5}\right), 7.43-7.64$ $\left(\mathrm{m}, 18 \mathrm{H}, \mathrm{C}_{6} \mathrm{H}_{5}\right) ;{ }^{11} \mathrm{~B}\left\{{ }^{1} \mathrm{H}\right\}: \delta_{\mathrm{B}}=-39.1(\mathrm{br}) ;{ }^{13} \mathrm{C}\left\{{ }^{1} \mathrm{H}\right\}: \delta_{\mathrm{C}}=15.12\left(\mathrm{~d},{ }^{2} J_{\mathrm{CP}}\right.$ $36.7 \mathrm{~Hz}, \mathrm{PCH}_{2}$ ), $19.23\left(\mathrm{~d},{ }^{1} J_{\mathrm{CP}} 83.5 \mathrm{~Hz}, \mathrm{PCH}_{2}\right), 23.11\left(\mathrm{~m}, \mathrm{AsCH}_{2}\right)$, $122.47\left[d,{ }^{1} J_{P C} 64.5 \mathrm{~Hz}, \mathrm{C}^{1}\left(\mathrm{PC}_{6} \mathrm{H}_{5}\right)\right], 129.12\left(\mathrm{C}_{6} \mathrm{H}_{5}\right), 129.21\left(\mathrm{C}_{6} \mathrm{H}_{5}\right)$, $130.03\left(\mathrm{~m}, \mathrm{C}_{6} \mathrm{H}_{5}\right), 133.18\left(\mathrm{t}, J_{\mathrm{PC}} 5.1 \mathrm{~Hz}, \mathrm{PC}_{6} \mathrm{H}_{5}\right), 133.59\left(\mathrm{C}_{6} \mathrm{H}_{5}\right)$, $139.33\left(\mathrm{AsC}_{6} \mathrm{H}_{5}\right)$. Acc. Mass: Found: $m / z=771.1442$. Calcd for $\mathrm{C}_{42} \mathrm{H}_{44}{ }^{75} \mathrm{As}_{2}{ }^{11} \mathrm{BP}_{2} 771.1443[\mathrm{M}]^{+}$. Crystal data: $\mathrm{C}_{42} \mathrm{H}_{44} \mathrm{As}_{2} \mathrm{BBrP}_{2}$, $M_{\mathrm{r}}=851.32, T=200(2) \mathrm{K}$, monoclinic, space group $C 2 / c, a=$ 27.9522(14), $b=13.3162(8), c=10.5732(5) \AA, \beta=91.9500(30)^{\circ}$, $V=3933.20(40) \AA^{3}, Z=4, D_{\text {calcd. }}=1.438 \mathrm{Mg} \mathrm{m}^{-3}, \mu($ Mo K $\alpha) 2.83$ $\mathrm{mm}^{-1}$, colourless block, $0.06 \times 0.11 \times 0.21 \mathrm{~mm}, 52052$ measured reflections with $2 \theta_{\max }=50.6^{\circ}, 3481$ independent reflections, 3481 absorption-corrected data used in $F^{2}$ refinement, 232 parameters, no restraints, $R_{1}=0.059, w R_{2}=0.128$ for 2768 reflections with $I>2 \sigma(I)$.

Synthesis of $\left[\mathrm{H}_{2} \mathrm{~B}\right.$ (triphos) $] \mathrm{Br}$ (17). A solution of $\mathrm{BrH}_{2} \mathrm{~B} \cdot \mathrm{SMe}_{2}$ $(1.0 \mathrm{M}, 0.80 \mathrm{~mL}, 0.80 \mathrm{mmol})$ in dichloromethane was added drop-wise to a stirred solution of triphos $(0.50 \mathrm{~g}, 0.80 \mathrm{mmol})$ in benzene $(40 \mathrm{~mL})$. Upon addition a precipitate formed in approximately $1 \mathrm{~min}$, and after $15 \mathrm{~min}$ the solution had lost its transient orange colour. The mixture was heated to reflux for 4 $h$, and then the solid was isolated by filtration to leave an offwhite powder that was further dried under high vacuum for several hours. The solid was recrystallised from a mixture of DCM/pentane to produce colourless X-ray diffraction quality crystals. Yield $0.318 \mathrm{~g}(0.44 \mathrm{mmol}, 55 \%)$. Partially melted at $c a$. $175^{\circ} \mathrm{C}$ to leave a glassy residue that remained unchanged up to $250^{\circ} \mathrm{C}$. The DCM solvate was confirmed to be present in the $\mathrm{X}-$ ray determination, however, it could not be modelled adequately and was subsequently removed with the PLATON program 'Squeeze'. Anal. Found: $\mathrm{C}, 60.76 ; \mathrm{H}, 5.37 ; \mathrm{N}, 0.00 \%$. Calcd for $\mathrm{C}_{41} \mathrm{H}_{41} \mathrm{BBrP}_{3} .1 .5\left(\mathrm{CH}_{2} \mathrm{Cl}_{2}\right): \mathrm{C}, 60.42 ; \mathrm{H}, 5.25 ; \mathrm{N}, 0.00 \%$. $\operatorname{NMR}\left(\mathrm{CD}_{2} \mathrm{Cl}_{2}, 25^{\circ} \mathrm{C}\right):{ }^{1} \mathrm{H}: \delta_{\mathrm{H}}=0.64\left(\mathrm{~s}, 3 \mathrm{H}, \mathrm{CH}_{3}\right), 3.17\left(\mathrm{~m}, 2 \mathrm{H}, \mathrm{CH}_{2}\right)$, $3.43\left(\mathrm{~m}, 2 \mathrm{H}, \mathrm{CH}_{2}\right), 3.68-3.86\left(\mathrm{~m}, 2 \mathrm{H}, \mathrm{CH}_{2}\right), 7.46-8.07(\mathrm{~m}, 3 \mathrm{OH}$, $\left.\mathrm{C}_{6} \mathrm{H}_{5}\right) ;{ }^{11} \mathrm{~B}\left\{{ }^{1} \mathrm{H}\right\}: \delta_{\mathrm{B}}=-39.1(\mathrm{br}) ;{ }^{13} \mathrm{C}\left\{{ }^{1} \mathrm{H}\right\}: \delta_{\mathrm{C}}=29.96\left(\mathrm{~d},{ }^{1} J_{\mathrm{CP}} 87.0 \mathrm{~Hz}\right.$, $\mathrm{CH}_{2}$ ), $32.87\left(\mathrm{dm},{ }^{1} J_{\mathrm{CP}}\right.$ unresolved, $\left.\mathrm{CH}_{2}\right), 35.77(\mathrm{Me}), 123.99$ [d, $\left.{ }^{1} J_{\mathrm{CP}} 63.2 \mathrm{~Hz}, \mathrm{C}^{1}\left(\mathrm{C}_{6} \mathrm{H}_{5}\right)\right], 126.52\left[\mathrm{~d},{ }^{1} J_{\mathrm{CP}} 62.1 \mathrm{~Hz}, \mathrm{C}^{1}\left(\mathrm{C}_{6} \mathrm{H}_{5}\right)\right], 129.42-$ $133.85\left(\mathrm{C}_{6} \mathrm{H}_{5}\right) ;{ }^{31} \mathrm{P}\left\{{ }^{1} \mathrm{H}\right\}: \delta_{\mathrm{P}}=-25.2\left(\mathrm{vbr}\right.$, pendant $\left.\mathrm{PPh}_{2}\right), 0.3(\mathrm{br}$, $\mathrm{P}_{2} \mathrm{~B}$ ). Acc. Mass: Found: $m / z=637.2510$. Calcd. for $\mathrm{C}_{41} \mathrm{H}_{41}{ }^{11} \mathrm{BP}_{3}$ $637.2514[\mathrm{M}]^{+}$. Crystal data: $\mathrm{C}_{41} \mathrm{H}_{41} \mathrm{BBrP}_{3}, M_{\mathrm{r}}=717.41, T=$ 200(2) K, triclinic, space group $P-1$ (No.2), $a=13.7686(6), b=$ 14.0695(5), $c=14.3983(6) \AA, \alpha=98.0020(20), \beta=114.3643(19)$, $\gamma=113.6510(20)^{\circ}, V=2166.66(18) \AA^{3}, Z=2, D_{\text {calcd. }}=1.100 \mathrm{Mg}$ $\mathrm{m}^{-3}, \mu$ (Mo K $\left.\alpha\right) 1.08 \mathrm{~mm}^{-1}$, colourless prism, $0.15 \times 0.17 \times 0.34$ $\mathrm{mm}, 36206$ measured reflections with $2 \theta_{\max }=50.7^{\circ}, 7713$ independent reflections, 7713 absorption-corrected data used in $F^{2}$ refinement, 415 parameters, no restraints, $R_{1}=0.048, w R_{2}$ $=0.150$ for 6309 reflections with $I>2 \sigma(I)$.

Partial oxidation of the pendant phosphine was observed, though the compound was not isolated.

[ $\mathrm{H}_{2} \mathrm{~B}$ (triphos $\left.\left.\{=\mathrm{O}\}\right)\right] \mathrm{Br}$ : NMR $\left(\mathrm{CDCl}_{3}, 25^{\circ} \mathrm{C}\right):{ }^{1} \mathrm{H}: \delta_{\mathrm{H}}=0.72(\mathrm{~s}, 3 \mathrm{H}$, $\left.\mathrm{CH}_{3}\right), 2.95\left(\mathrm{~m} . \mathrm{br}, 2 \mathrm{H}, \mathrm{CH}_{2}\right), 3.47\left(\mathrm{~d},{ }^{2} \mathrm{JHH}_{\mathrm{PH}} 7.6 \mathrm{~Hz}, 1 \mathrm{H}, \mathrm{CH}_{2}\right), 3.74$ (d, $\left.2 J_{\mathrm{PH}} 12.4 \mathrm{~Hz}, 1 \mathrm{H}, \mathrm{CH}_{2}\right), 4.16-4.33\left(\mathrm{~m}, 2 \mathrm{H}, \mathrm{CH}_{2}\right), 7.48-8.04(\mathrm{~m}, 3 \mathrm{OH}$, $\left.\mathrm{C}_{6} \mathrm{H}_{5}\right) ;{ }^{11} \mathrm{~B}\left\{{ }^{1} \mathrm{H}\right\}: \delta_{\mathrm{B}}=-39.4(\mathrm{br}) ;{ }^{31} \mathrm{P}\left\{{ }^{1} \mathrm{H}\right\}: \delta_{\mathrm{P}}=-0.3\left(v b r, \mathrm{P}_{2} \mathrm{~B}\right), 29.9$ $\left(\mathrm{O}=\mathrm{PPh}_{2}\right)$.

Synthesis of $\left[\mathrm{H}_{2} \mathrm{~B}\left(\mathrm{PHCy}_{2}\right)_{2}\right]\left[\mathrm{SbF}_{6}\right]$ (18). A DCM (4 mL) solution of $\left[\mathrm{H}_{2} \mathrm{~B}\left(\mathrm{PHCy}_{2}\right)_{2}\right] \mathrm{Br}(0.49 \mathrm{~g}, 1.0 \mathrm{mmol})$ was added via cannula to a THF (4 mL) solution of $A g\left[\mathrm{SbF}_{6}\right](0.34 \mathrm{~g}, 1.0 \mathrm{mmol})$ to instantaneously give an off-white coloured precipitate ( $\mathrm{AgBr}$ ) and a colourless solution. The filtrate was isolated by cannula filtration and all volatiles were removed under high vacuum to leave a white residue, which was further dried under high vacuum overnight. The residue was dissolved in THF, layered with pentane and stored at $-20^{\circ} \mathrm{C}$ to give mostly beige powder and some colourless crystals of X-ray diffraction quality. The compound was found to decompose over a period of several weeks under an inert atmosphere. Yield $0.603 \mathrm{~g}(0.94 \mathrm{mmol}$, 93\%). Anal. Found: C, 44.73; H, 7.52; N, 0.00\%. Calcd for $\mathrm{C}_{24} \mathrm{H}_{48} \mathrm{BF}_{6} \mathrm{P}_{2} \mathrm{Sb}: \mathrm{C}, 44.68 ; \mathrm{H}, 7.50 ; \mathrm{N}, 0.00 \%$. NMR $\left(\mathrm{CDCl}_{3}, 25^{\circ} \mathrm{C}\right)$ : ${ }^{1} \mathrm{H}: \delta_{\mathrm{H}}=1.21-2.16\left(\mathrm{~m}, 44 \mathrm{H}, \mathrm{C}_{6} \mathrm{H}_{11}\right), 4.89\left(\mathrm{~d},{ }^{1} J_{\mathrm{PH}} 400.7 \mathrm{~Hz}, 2 \mathrm{H}, \mathrm{PH}\right)$; ${ }^{11} \mathrm{~B}\left\{{ }^{1} \mathrm{H}\right\}: \delta_{\mathrm{B}}=-45.1(\mathrm{br}) ;{ }^{13} \mathrm{C}\left\{{ }^{1} \mathrm{H}\right\}: \delta_{\mathrm{C}}=25.47\left(\mathrm{C}_{6} \mathrm{H}_{11}\right), 26.43\left(\mathrm{C}_{6} \mathrm{H}_{11}\right)$, $28.81\left(\mathrm{C}_{6} \mathrm{H}_{11}\right), 29.31\left[\mathrm{~d},{ }^{1} \mathrm{JPC}_{\mathrm{PC}} 41.5 \mathrm{~Hz}, \mathrm{C}^{1}\left(\mathrm{C}_{6} \mathrm{H}_{11}\right)\right] ;{ }^{31} \mathrm{P}\left\{{ }^{1} \mathrm{H}\right\}: \delta_{\mathrm{P}}=-3.3$ (d.br, ${ }^{1} J_{\mathrm{PB}} 80 \mathrm{~Hz}$ ). Acc. Mass: Found: $m / z=409.3325$. Calcd. for $\mathrm{C}_{24} \mathrm{H}_{48}{ }^{11} \mathrm{BP}_{2} 409.3324[\mathrm{M}]^{+}$. ESI-MS (-ve ion): $\mathrm{m} / z=235.2\left[\mathrm{SbF}_{6}\right]^{-}$ . Crystal data: $\left[\mathrm{C}_{24} \mathrm{H}_{48} \mathrm{BP}_{2}\right]\left[\mathrm{SbF}_{6}\right], M_{\mathrm{r}}=643.13, T=200(2) \mathrm{K}$, monoclinic, space group $P 2_{1} / n, a=10.2490(2), b=19.1746(7)$, $c=15.1472(5) \AA, \beta=91.516(2)^{\circ}, V=2975.69(16) \AA^{3}, Z=4, D_{\text {calcd. }}$. $=1.435 \mathrm{Mg} \mathrm{m}^{-3}, \mu(\mathrm{Mo} \mathrm{K} \alpha) 1.08 \mathrm{~mm}^{-1}$, colourless prism, $0.12 \times$ $0.12 \times 0.41 \mathrm{~mm}, 33770$ measured reflections with $2 \theta_{\max }=55.0^{\circ}$, 6792 independent reflections, 6784 absorption-corrected data 
used in $F^{2}$ refinement, 308 parameters, no restraints, $R_{1}=0.056$, $w R_{2}=0.150$ for 4882 reflections with $I>2 \sigma(I)$.

Synthesis of $\left[\mathrm{H}_{2} \mathrm{~B}\left(\mathrm{PMe}_{2} \mathrm{Ph}\right)_{2}\right]\left[\mathrm{AsF}_{6}\right]$ (19). A solution of $\left[\mathrm{H}_{2} \mathrm{~B}\left(\mathrm{PMe}{ }_{2} \mathrm{Ph}\right)_{2}\right] \mathrm{Br}(0.29 \mathrm{~g}, 0.79 \mathrm{mmol})$ in $\mathrm{DCM}(4 \mathrm{~mL})$ was transferred via cannula into a THF $(4 \mathrm{~mL})$ solution of $\mathrm{K}\left[\mathrm{AsF}_{6}\right]$ $(0.18 \mathrm{~g}, 0.79 \mathrm{mmol})$ to instantaneously form a white precipitate $(\mathrm{KBr})$. The filtrate was separated via cannula filtration and all volatiles were removed under high vacuum to leave an orange solid. Vapour diffusion with pet. ether $60-80^{\circ} \mathrm{C}$ into a concentrated chloroform solution of the compound over two days yielded X-ray diffraction quality colourless crystals. Yield $0.33 \mathrm{~g}$ (0.68 mmol, 87\%). Anal. Found: C, 39.99; H, 4.94; N, $0.02 \%$. Calcd. for $\mathrm{C}_{16} \mathrm{H}_{24} \mathrm{AsBF}_{6} \mathrm{P}_{2}$ : C, 40.20; $\mathrm{H}, 5.06 ; \mathrm{N}, 0.00 \%$. $\operatorname{NMR}\left(\mathrm{CDCl}_{3}, 25^{\circ} \mathrm{C}\right):{ }^{1} \mathrm{H}: \delta_{\mathrm{H}}=1.68\left(\mathrm{~d},{ }^{2} \mathrm{~J}_{\mathrm{PH}} 12.0 \mathrm{~Hz}, 12 \mathrm{H}, \mathrm{CH}_{3}\right), 7.50-$ $7.53\left(\mathrm{~m}, 10 \mathrm{H}, \mathrm{C}_{6} \mathrm{H}_{5}\right) ;{ }^{11} \mathrm{~B}\left\{{ }^{1} \mathrm{H}\right\}: \delta_{\mathrm{B}}=-32.0\left(\mathrm{t} . \mathrm{br},{ }^{1} J_{\mathrm{BP}} 87 \mathrm{~Hz}\right) ;{ }^{11} \mathrm{~B}: \delta_{\mathrm{B}}$ $=-32.0$ (quintet.br, ${ }^{1} J_{\mathrm{BH}} \approx{ }^{1} J_{\mathrm{BP}} 95 \mathrm{~Hz}$ ); ${ }^{13} \mathrm{C}\left\{{ }^{1} \mathrm{H}\right\}: \delta_{\mathrm{C}}=11.10$ (dd, $\left.1 J_{\mathrm{CP}} /{ }^{3} J_{\mathrm{CP}} 47.3 / 2.5 \mathrm{~Hz}, \mathrm{CH}_{3}\right), 125.58\left[\mathrm{~d},{ }^{1} \mathrm{JP}_{\mathrm{CP}} 69.5 \mathrm{~Hz}, \mathrm{C}^{1}\left(\mathrm{C}_{6} \mathrm{H}_{5}\right)\right]$, $130.08\left[\mathrm{~m}, \mathrm{C}^{3,5}\left(\mathrm{C}_{6} \mathrm{H}_{5}\right)\right], 130.51\left[\mathrm{~m}, \mathrm{C}^{2,6}\left(\mathrm{C}_{6} \mathrm{H}_{5}\right)\right], 132.9\left[\mathrm{C}^{4}\left(\mathrm{C}_{6} \mathrm{H}_{5}\right)\right]$; ${ }^{31} \mathrm{P}\left\{{ }^{1} \mathrm{H}\right\}: \delta_{\mathrm{P}}=-3.6$ [q.br, ${ }^{1} J_{\mathrm{PB}} 79 \mathrm{~Hz}$ (Average)]. Acc. Mass: Found: $\mathrm{m} / \mathrm{z}=289.1446$ Calcd. for $\mathrm{C}_{16} \mathrm{H}_{24}{ }^{11} \mathrm{BP}_{2} 289.1446$ [M] ${ }^{+}$. ESI-MS (ve ion): $m / z=189.2[\mathrm{M}]$. Crystal data: $\left[\mathrm{C}_{16} \mathrm{H}_{24} \mathrm{BP}_{2}\right]\left[\mathrm{AsF}_{6}\right], M_{\mathrm{r}}=$ 478.03, $T=200(2) \mathrm{K}$, monoclinic, space group $P 2_{1} / n, a=$ 11.0302(1), $b=16.4541(2), c=35.0725(5) \AA, \beta=93.3927(5)^{\circ}, V$ $=6354.22(13) \AA^{3}, Z=12, D_{\text {calcd. }}=1.499 \mathrm{Mg} \mathrm{m}^{-3}, \mu($ Mo K $\alpha) 1.80$ $\mathrm{mm}^{-1}$, colourless plate, $0.07 \times 0.14 \times 0.42 \mathrm{~mm}, 77060$ measured reflections with $2 \theta_{\max }=55.0^{\circ}, 14566$ independent reflections, 14557 absorption-corrected data used in $F^{2}$ refinement, 703 parameters, 36 restraints, $R_{1}=0.061, w R_{2}=0.161$ for 10395 reflections with $I>2 \sigma(I)$.

Synthesis of $\left[\mathrm{H}_{2} \mathrm{~B}\right.$ (triphos)][AsF $\left.\mathrm{F}_{6}\right]$ (20). A solution of $\left[\mathrm{H}_{2} \mathrm{~B}\right.$ (triphos) $] \mathrm{Br}(1.763 \mathrm{~g}, 2.46 \mathrm{mmol})$ in $\mathrm{DCM}(8 \mathrm{~mL})$ was added via cannula to a THF $(4 \mathrm{~mL})$ solution of $\mathrm{K}\left[\mathrm{AsF}_{6}\right](0.56 \mathrm{~g}, 2.46$ $\mathrm{mmol}$ ) to initially give a white precipitate and colourless solution. The white precipitate $(\mathrm{KBr})$ was separated by cannula filtration and discarded, whilst the filtrate was added to a second equivalent of $\mathrm{K}\left[\mathrm{AsF}_{6}\right](0.56 \mathrm{~g}, 2.46 \mathrm{mmol})$ to again give a white precipitate. The precipitate (mixture of $\mathrm{KBr}$ and unreacted $\mathrm{K}\left[\mathrm{AsF}_{6}\right]$ ) was separated by cannula filtration and again discarded. All volatiles were removed under high vacuum to leave a white solid. The solid was dissolved in acetone (14 $\mathrm{mL}$ ) and precipitated by dilution with $\mathrm{Et}_{2} \mathrm{O}$, then separated by cannula filtration and washed with benzene $(15 \mathrm{~mL})$ and dried in vacuo. Yield $1.366 \mathrm{~g}$ (1.65 mmol, 67\%). A minor contamination of $\left[\mathrm{H}_{2} \mathrm{~B}\right.$ (triphos) $\left.\left(\mathrm{BH}_{2} \mathrm{Br}\right)\right]\left[\mathrm{AsF}_{6}\right]$ was found to be present in $\sim 10 \%$ yield, but all attempts to remove this contamination failed. The solid was recrystallized from a mixture of DCM/acetone/pentane at $-15^{\circ} \mathrm{C}$ over $48 \mathrm{~h}$ to produce colourless $\mathrm{X}$-ray diffraction quality crystals. NMR $\left(\mathrm{CDCl}_{3}, 25^{\circ} \mathrm{C}\right)$ : ${ }^{1} \mathrm{H}: \delta_{\mathrm{H}}=0.72\left(\mathrm{~s}, 3 \mathrm{H}, \mathrm{CH}_{3}\right), 2.67\left(\mathrm{~s} . \mathrm{br}, 2 \mathrm{H}, \mathrm{CH}_{2}\right), 2.72-2.84(\mathrm{~m}, 2 \mathrm{H}$, $\left.\mathrm{CH}_{2}\right), 3.20\left(\mathrm{t},{ }^{2} J_{\mathrm{PH}} /{ }^{2} J_{\mathrm{HH}} 14.6 \mathrm{~Hz}\right.$ (Average), $\left.2 \mathrm{H}, \mathrm{CH}_{2}\right), 7.28-7.36(\mathrm{~m}$, $\left.4 \mathrm{H}, \mathrm{C}_{6} \mathrm{H}_{5}\right), 7.40-7.63\left(\mathrm{~m}, 21 \mathrm{H}, \mathrm{C}_{6} \mathrm{H}_{5}\right), 7.79-7.90\left(\mathrm{~m}, 5 \mathrm{H}, \mathrm{C}_{6} \mathrm{H}_{5}\right)$; ${ }^{11} \mathrm{~B}\left\{{ }^{1} \mathrm{H}\right\}: \delta_{\mathrm{B}}=-39.6(\mathrm{br}) ;{ }^{13} \mathrm{C}\left\{{ }^{1} \mathrm{H}\right\}: \delta_{\mathrm{C}}=29.74\left(\mathrm{CH}_{3}\right), 32.62\left(\mathrm{CH}_{2}\right)$, $33.08\left(\mathrm{CH}_{2}\right), 38.80(\mathrm{CMe}), 123.41\left[\mathrm{~d},{ }^{1} J_{\mathrm{CP}} 68.5 \mathrm{~Hz}, \mathrm{C}^{1}\left(\mathrm{C}_{6} \mathrm{H}_{5}\right)\right]$, $126.22\left[\mathrm{dd},{ }^{1} J_{\mathrm{CP}} / J_{\mathrm{CP}} 70.1 / 9.2 \mathrm{~Hz}, \mathrm{C}^{1}\left(\mathrm{C}_{6} \mathrm{H}_{5}\right)\right], 129.56-133.49\left(\mathrm{C}_{6} \mathrm{H}_{5}\right)$; ${ }^{31} \mathrm{P}\left\{{ }^{1} \mathrm{H}\right\}: \delta_{\mathrm{P}}=-25.1\left(\mathrm{br}\right.$, pendant $\left.\mathrm{PPh}_{2} \mathrm{R}\right),-4.8(\mathrm{br}$, pendant $\mathrm{PPh}_{2} \cdot \mathrm{BH}_{2} \mathrm{Br}$ contaminant), -0.2 [vbr, $\left.\mathrm{P}_{2} \mathrm{~B}\right]$. ESI-MS (+ve ion): $\mathrm{m} / \mathrm{z}$ $=637.5[\mathrm{M}]^{+}$; ESI-MS (-ve ion): $m / z=189.2[\mathrm{M}]^{-}$. Crystal data:
$\left[\mathrm{C}_{41} \mathrm{H}_{41} \mathrm{BP}_{3}\right]\left[\mathrm{AsF}_{6}\right] \cdot \mathrm{H}_{2} \mathrm{O}, \mathrm{Mr}_{\mathrm{r}}=844.43, T=200(2) \mathrm{K}$, monoclinic, space group $P 2_{1} / n, a=13.2239(6), b=21.5110(9), c=$ 14.3499(4) $\AA, \beta=100.315(2), V=4016.0(3) \AA^{3}, Z=4, D_{\text {calcd }}=$ $1.397 \mathrm{Mg} \mathrm{m}^{-3}, \mu($ Mo K $\alpha) 1.03 \mathrm{~mm}^{-1}$, colourless prism, $0.06 \times 0.07$ $\times 0.37 \mathrm{~mm}, 55977$ measured reflections with $2 \theta_{\max }=52.2^{\circ}$, 7922 independent reflections, 7920 absorption-corrected data used in $F^{2}$ refinement, 478 parameters, 36 restraints, $R_{1}=0.072$, $w R_{2}=0.193$ for 3988 reflections with $I>2 \sigma(I)$.

$\left[\mathrm{H}_{2} \mathrm{~B}\right.$ (triphos $\left.\left.\{=\mathbf{O}\}\right)\right]\left[\mathrm{AsF}_{6}\right]$. The solid was recrystallized in air from a mixture of acetone/pentane at $25^{\circ} \mathrm{C}$ over $48 \mathrm{~h}$ to produce colourless $\mathrm{X}$-ray diffraction quality crystals of the oxide decomposition product. Crystal data: $\mathrm{C}_{41} \mathrm{H}_{41} \mathrm{AsBF}_{6} \mathrm{O}_{0.6} \mathrm{P}_{3} .0 .4\left(\mathrm{H}_{2} \mathrm{O}\right), M_{\mathrm{r}}=843.22, T=200(2) \mathrm{K}$, monoclinic, space group $P 2_{1} / n, a=13.0162(3), b=21.4161(5)$, $c=14.4005(2) \AA, \beta=97.8708(13), V=3976.41(14) \AA^{3}, Z=4, D_{\text {calcd }}$ $=1.408 \mathrm{Mg} \mathrm{m}^{-3}, \mu($ Mo K $\alpha) 1.04 \mathrm{~mm}^{-1}$, colourless prism, $0.09 \times$ $0.15 \times 0.45 \mathrm{~mm}, 17904$ measured reflections with $2 \theta_{\max }=55.0^{\circ}$, 9120 independent reflections, 9119 absorption-corrected data used in $F^{2}$ refinement, 487 parameters, 200 restraints, $R_{1}=$ $0.056, w R_{2}=0.152$ for 6292 reflections with $I>2 \sigma(I)$. Crystal data: $\mathrm{C}_{41} \mathrm{H}_{41} \mathrm{AsBF}_{6} \mathrm{OP}_{3}, M_{\mathrm{r}}=842.42, T=200(2) \mathrm{K}$, monoclinic, space group $P 2_{1} / n, a=12.7639(3), \quad b=21.4218(5), c=$ $14.4115(2) \AA, \beta=95.4493(13), V=3922.67(14) \AA^{3}, Z=4, D_{\text {calcd }}=$ $1.426 \mathrm{Mg} \mathrm{m}^{-3}, \mu($ Mo K $\alpha) 1.05 \mathrm{~mm}^{-1}$, colourless prism, $0.08 \times 0.13$ $\times 0.28 \mathrm{~mm}, 58122$ measured reflections with $2 \theta_{\max }=50.0^{\circ}$, 6921 independent reflections, 6919 absorption-corrected data used in $F^{2}$ refinement, 478 parameters, 201 restraints, $R_{1}=$ $0.052, w R_{2}=0.135$ for 4974 reflections with $I>2 \sigma(I)$.

\section{Acknowledgements}

This work was supported by the Australian Research Council (DP130102598).

\section{Notes and references}

+ The $\left[\mathrm{H}_{2} \mathrm{~B}\left(\mathrm{PMe}_{2} \mathrm{Ph}\right]_{2}\right]^{+}$cation has been previously synthesised as $\left[\mathrm{H}_{2} \mathrm{~B}\left(\mathrm{PMe}_{2} \mathrm{Ph}\right]_{2}\right]\left[\mathrm{B}(\mathrm{Cat})_{2}\right]$ by alternative methods. ${ }^{7 e}$

$¥$ Disproportionation is commonly observed to occur over time for these reagents.

$¥ ¥$ In contrast to $\left[\mathrm{H}_{2} \mathrm{~B}\left(\mathrm{PHCy}_{2}\right)\left(\mathrm{PHPh}_{2}\right)\right] \mathrm{Br},{ }^{2} J_{\mathrm{PP}}$ was not observed for $\left[\mathrm{H}_{2} \mathrm{~B}\left(\mathrm{PH}_{2} \mathrm{Cy}\right)(\mathrm{PHCy})\right] \mathrm{Br}$. However, its identity was clearly established by the difference in the ${ }^{31} \mathrm{P} N M R$ resonances from $\left[\mathrm{H}_{2} \mathrm{~B}\left(\mathrm{PH}_{2} \mathrm{Cy}\right)_{2}\right] \mathrm{Br}$ $\left(\delta_{p}-38.6\right)$ and $\left[\mathrm{H}_{2} \mathrm{~B}\left(\mathrm{PHCy}_{2}\right)_{2}\right] \mathrm{Br}\left(\delta_{\mathrm{p}}-0.4\right)$.

¥¥ Satisfactory microanalysis could not be obtained due to decomposition in the solid state, even under an inert atmosphere.

1 T. Chivers and I. Manners, Inorganic rings and polymers of the p-block elements : from fundamentals to applications, RSC Pub, 2009.

2 a) D. W. Stephan and G. Erker, Angew. Chem., Int. Ed. 2010, 49, 46-76. (b) D. W. Stephan, Nat. Chem. 2014, 6, 952-953. (c) Chen, D.; Klankermayer, A. Top. Curr. Chem. 2013, 334, $1-26$.

3 S. G. Shore and R. W. Parry, J. Am. Chem. Soc., 1955, 77, 60846085 . 
4 D. R. Schultz and R. W. Parry, J. Am. Chem. Soc., 1958, 80, 48.

5 W. E. Piers, S. C. Bourke and K. D. Conroy, Angew. Chem. Int. Ed., 2005, 44, 5016-5036.

6 R. Kinjo, B. Donnadieu, M. A. Celik, G. Frenking and G. Bertrand, Science, 2011, 333, 610-613.

7 a) N. E. Miller and E. L. Muetterties, J. Am. Chem. Soc. 1964, 86, 1033-1038. b) T. B. Pennington, M. A. Chiusano, J. D. Dye, E. D. Martin, and D. R. Martin, J. Inorg. Nucl. Chem. 1978, 40, 389-394. c) D. R. Martin, C. M. Merkel, J. P. Ruiz and J. U. Mondal, Inorg. Chim. Acta, 1985, 100, 293-297. d) D. R. Martin, C. M. Merkel and J. P. Ruiz, Inorg. Chim Acta, 1986, 115, L29-L30. e) S. A. Westcott, H. P. Blom, T. B. Marder, R. T. Baker and J. C. Calabrese, Inorg. Chem., 1993, 32, 2175-2182. f) T. Miyazaki, M. Sugawara, H. Danjo and T. Imamoto, Tetrahedron Lett. 2004, 45, 93419344. g) Y. Yamamoto, T. Koizumi, K. Katagiri, Y. Furuya, H. Danjo, T. Imamoto, and K. Yamaguchi, Org. Lett., 2006, 8, 6103-6106. h) K. Owsianik, R. Chauvin, A. Balinska, M. Wieczorek, M. Cypryk and M. Mikolajczyk, Organometallics, 2009, 28, 4929-4937. i) T. A. Shuttleworth, M. A. Huertos, I. Pernik, R. D. Young and A. S. Weller, Dalton Trans. 2013, 42, 12917-12925. j) T. N. Hooper, M. A. Huertos, T. Jurca, S. D. Pike, A. S. Weller and I. Manners, Inorg. Chem. 2014, 53, 3716-3729.

8 a) T. Costa and H. Schmidbaur, Chem. Ber., 1982, 115, 13741378. b) H. Schmidbaur, E. Weiss and W. Graf, Organometallics, 1985, 4, 1233-1237. c) H. Schmidbaur, T. Wimmer, G. Reber and G. Müller, Angew. Chem., Int. Ed., 1988, 27, 1071-1074. d) H. Schmidbaur, C. Paschalidis, O. Steigelmann, and G. Müller, Chem. Ber., 1989, 122, 18511855. e) H. Schmidbaur, T. Wimmer, A. Grohmann, O. Steigelmann and G. Müller, Chem. Ber., 1989, 122, 16071612. f) H. Schmidbaur, S. Gamper, C. Paschalidis, $O$. Steigelmann and G. Müller, Chem. Ber., 1991, 124, 15251530. g) M. Sigl, A. Schier and H. Schmidbaur, Chem. Ber., 1997, 130, 1411-1416.

9 C. Marquardt, C. Thoms, A. Stauber, G. Balazs, M. Bodensteiner and M. Scheer, Angew. Chem., Int. Ed., 2014, 53 3727-3734.

10 F.Dornhaus, H.-W.Lerner and M.Bolte, Acta Crystallogr., Sect. E: Struct. Rep. Online, 2008, 64, m835.

11 C. A. Tolman, Chem. Rev., 1977, 77, 313-348.

12 a) J. B. Leach, M. A. Toft, F. L. Himpsl and S. G. Shore, J. Am. Chem. Soc., 1981, 103, 988-989. b) M. A. Toft, J. B. Leach, F. L. Himpsl and S. G. Shore, Inorg. Chem., 1982, 21, 1952-1957. c) L. A. Gavrilova, L. V. Titov and V. Y. Rosolovskii, Z. Neorg. Khim. 1981, 26, 1769-1774.

13 K. J. Donaghy, A. P. J. Carroll and L. G. Sneddon, Inorg. Chem., 1997, 36, 547-553.

14 a) I. R. Butler, W. R. Cullen, T. J. Kim, S. J. Rettig and J. Trotter, Organometallics, 1985, 4, 972-980. b) G. M. Whitesides, J. F. Gaasch and E. R. Stedronsky, J. Am. Chem. Soc., 1972, 94, 5258-5270. c) D. A. Clemente, G. Pilloni, B. Corain, B. Longato and M. Tiripicchio-Camellini, Inorg. Chim. Acta, 1986, 115, L9L11.

15 D. Seyferth, B. W. Hames, T. G. Rucker, M. Cowie and R. S. Dickson, Organometallics, 1983, 2, 472-474.

16 a) A. Davison and J. C. Smart, J. Organomet. Chem., 1969, 19, P7-P8. b) J. J. Bishop, A. Davison, M. L. Katcher, D. W. Lichtenberg, R. E. Merrill and J. C. Smart, J. Organomet. Chem. 1971, 27, 241-249.

17 a) J. L. Atwood, S. G. Bott, C. M. Means, A. W. Coleman, H. Zhang and M. T. May, Inorg. Chem., 1990, 29, 467-470. b) E. L. Norton, K. L. S. Szekely, J. W. Dube, A. P. G. Bomben and C. L. B. Macdonald, Inorg. Chem., 2008, 47, 1196-1203. c) R. R. Butorac, S. S. Al-Deyab and A. H. Cowley, Molecules, 2011, 16, 3168-3178.

18 J. Burt, J. W. Emsley, W. Levason, G. Reid and I. S. Tinkler, Inorg. Chem., 2016, 55, 8852.
19 a) L. Pauling, J. Am. Chem. Soc., 1932, 54, 3570-3582. b) R. H. Crabtree, P. E. M. Siegbahn, O. Eisenstein, A. L. Rheingold and T. F. Koetzle, Acc. Chem. Res., 1996, 29, 348-354. c) N. V. Belkova, E. S. Shubina and L. M. Epstein, Acc. Chem. Res., 2005, 38, 624-631.

\section{Text for Table of Contents}

The reactions of $\mathrm{BrH}_{2} \mathrm{~B} \cdot \mathrm{SMe}_{2}$ or $\mathrm{Br}_{2} \mathrm{HB}_{2} \mathrm{SMe}_{2}$ with a variety of primary, secondary, tertiary and chelating phosphines affords a range of boronium salts of the form $\left[\mathrm{HXB}\left(\mathrm{PR}_{3}\right)_{2}\right] \mathrm{Br}(\mathrm{X}=\mathrm{H}, \mathrm{Br})$, e.g., the ferrocenophane shown. The equilibrium between such species and the neutral haloborane adducts $\mathrm{HXBr}\left(\mathrm{PR}_{3}\right)$ is discussed.

\section{Graphic for Table of Contents}

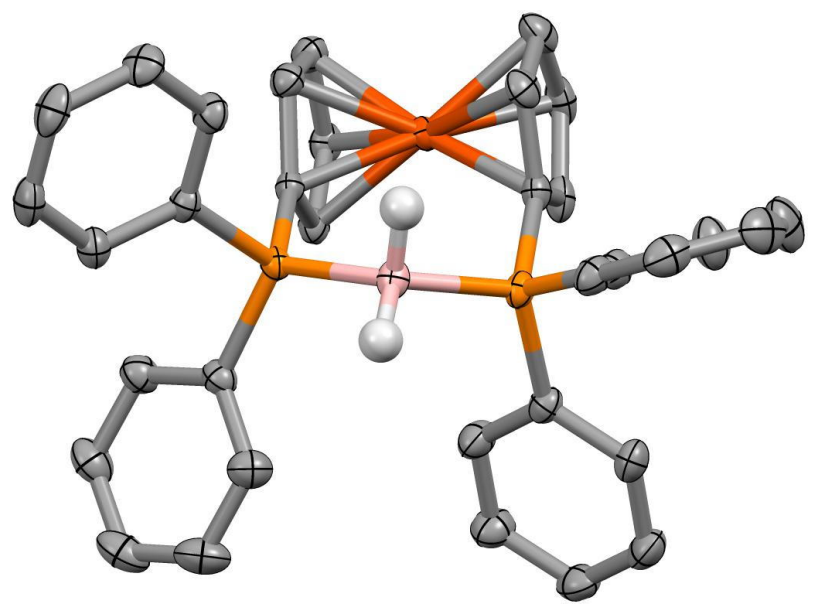

